\title{
Review \\ Drug Design Targeting the Muscarinic Receptors and the Implications in Central Nervous System Disorders
}

\author{
Chad R. Johnson ${ }^{1} * \mathbb{C}$, Brian D. Kangas ${ }^{2}$, Emily M. Jutkiewicz ${ }^{3}$, Jack Bergman ${ }^{2}$ and Andrew Coop ${ }^{1}$ \\ 1 Department of Pharmaceutical Sciences, University of Maryland School of Pharmacy, Pharmacy Hall North \\ Room 623, 20 N. Pine St., Baltimore, MD 21202, USA; acoop@rx.umaryland.edu \\ 2 Behavioral Biology Program, McLean Hospital, Harvard Medical School, 115 Mill St., \\ Belmont, MA 02478, USA; bkangas@mclean.harvard.edu (B.D.K.); jack_bergman@hms.harvard.edu (J.B.) \\ 3 Department of Pharmacology, University of Michigan, 1150 W. Medical Center Dr., \\ Ann Arbor, MI 48109, USA; ejutkiew@umich.edu \\ * Correspondence: chad.johnson@rx.umaryland.edu; Tel.: +1-410-706-2029; Fax: +1-410-706-5017
}

Citation: Johnson, C.R.; Kangas, B.D.; Jutkiewicz, E.M.; Bergman, J.; Coop, A. Drug Design Targeting the Muscarinic Receptors and the Implications in Central Nervous System Disorders. Biomedicines 2022, 10, 398. https://doi.org/10.3390/ biomedicines 10020398

Academic Editor: Zhenglin Gu

Received: 16 December 2021

Accepted: 26 January 2022

Published: 7 February 2022

Publisher's Note: MDPI stays neutral with regard to jurisdictional claims in published maps and institutional affiliations.

Copyright: (C) 2022 by the authors. Licensee MDPI, Basel, Switzerland. This article is an open access article distributed under the terms and conditions of the Creative Commons Attribution (CC BY) license (https:// creativecommons.org/licenses/by/ $4.0 /)$

\begin{abstract}
There is substantial evidence that cholinergic system function impairment plays a significant role in many central nervous system (CNS) disorders. During the past three decades, muscarinic receptors ( $\mathrm{mAChRs}$ ) have been implicated in various pathologies and have been prominent targets of drug-design efforts. However, due to the high sequence homology of the orthosteric binding site, many drug candidates resulted in limited clinical success. Although several advances in treating peripheral pathologies have been achieved, targeting CNS pathologies remains challenging for researchers. Nevertheless, significant progress has been made in recent years to develop functionally selective orthosteric and allosteric ligands targeting the mAChRs with limited side effect profiles. This review highlights past efforts and focuses on recent advances in drug design targeting these receptors for Alzheimer's disease (AD), schizophrenia (SZ), and depression.
\end{abstract}

Keywords: Alzheimer's disease; schizophrenia; depression; major depressive disorder; drug design; muscarinic receptors; muscarinic agonist; muscarinic antagonist; positive allosteric modulator

\section{Introduction}

With nearly 800 human genes coding for them, G protein-coupled receptors (GPCRs) are a large family of plasma membrane proteins that are highly conserved throughout evolution [1]. The successful development of multicellular organisms was, in part, dependent on the evolution of these proteins, which serve to translate extracellular signals to intracellular functions, thereby facilitating communications between cells and their environment [2]. GPCRs are widely present in most life forms, including bacteria, fungi, and higher animals, and are involved in nearly all aspects of animal physiology [3]. They facilitate several cell signaling transduction cascades that regulate various critical cellular processes and have been implicated in a wide range of biological functions, including behavior, cognition, immune response, mood, olfaction, blood pressure regulation, and taste, among others $[4,5]$.

The cell membrane location and diversity of tissue expression of GPCRs make them ideal targets for drug discovery. Out of the 219 new molecular entities (NMEs) approved by the US Food and Drug Administration (FDA) from 2005-2014, 54 ( 25\%) targeted GPCRs [6]. Approximately 80 known GPCRs are currently targeted by approved therapies ( 10\% of the known coded receptors), leaving considerable room to discover novel compounds. However, this task has been complicated by the (1) commonality of ligands targeting subfamilies of GPCRs; (2) the high homology among ligand binding sites; and (3) difficulty obtaining 3-dimensional structures of the receptors in both their active/inactive states.

The muscarinic acetylcholine receptors (mAChRs) are a family of five closely related class A GPCRs $\left(\mathrm{M}_{1}-\mathrm{M}_{5}\right)$ encoded by the CHRM1-CHRM5 genes, which have been highly 
conserved throughout evolution [7]. In addition to the key role of mAChRs in the autonomic nervous system, they further regulate several essential central nervous system functions, including those involved in cognition as well as motor and sensory function. In turn, disturbances in $\mathrm{mAChR}$ function have been implicated in Alzheimer's disease (AD), Parkinson's disease, depression, and schizophrenia (SZ).

The first $m A C h R$ structure $\left(M_{2}\right)$ was promulgated by Haga et al. [8] in 2012, serving as a significant breakthrough in structure determination for the mAChRs. The receptor was crystallized in its inactive conformation bound to the inverse agonist 3-Quinuclidinyl benzilate (QNB), providing a snapshot of the orthosteric binding pocket and identifying potential allosteric sites in the extracellular loops (ECLs, near the aromatic cap). The $\mathrm{M}_{3}$ receptor structure bound to tiotropium (Spiriva), a treatment for asthma/COPD, was similar to $\mathrm{M}_{2}$, including its intracellular and extracellular loops [9]. In 2016, crystallization of the $\mathrm{M}_{1,4}$ receptors revealed only slight differences in the orthosteric sites but confirmed larger differences in the allosteric binding sites on the ECLs, potentially offering an opportunity to achieve mAChR subtype selectivity [10]. Along these lines, mAChR (CHRM1-CHRM5) knockout $(\mathrm{KO})$ mice [7] have provided valuable insights into the physiological and pathophysiological roles of the individual subtypes (reviewed in Wess et al. [11]).

Thus, the cholinergic system offers exciting opportunities for researchers in academia and industry alike, and in particular, the cholinergic system continues to provide fertile ground for drug design and discovery. The present review adopts a chronological approach to highlight the historical developments (e.g., the cholinergic hypothesis and Merck's early efforts designing $\mathrm{mAChR}$ agonists) and shifts to more recent drug development efforts and design (e.g., allosteric modulators and select orthosteric compounds), specifically for AD, $\mathrm{SZ}$, and major depressive disorder (MDD). In addition, although not exhaustive, some of the most promising compounds and chemical scaffolds will be discussed to illustrate their potential value for treating these pathologies.

\section{Drug Design Targeting the mAChRs: Alzheimer's Disease}

\subsection{Orthosteric Agonists}

Active research efforts in the 1960s-1980s helped to develop an understanding of neurotransmitters' physiological roles, which ultimately led to the consideration that the altered function of neurotransmitter pathways was associated with several CNS disorders [12]. This was validated via a tissue analysis of samples from the brains of postmortem $A D$ patients, which revealed a cholinergic projection deficit from the basal forebrain neuronal population (nucleus basalis magnocellularis of Meynert) to the cortex and hippocampus. Furthermore, the activity of choline acetyltransferase (ChAT), the enzyme primarily responsible for the synthesis of acetylcholine and a marker of cholinergic neurons/synapses, was found to be significantly decreased in the cortex/hippocampus of AD patients [13,14]. Finally, depolarization-induced acetylcholine release and choline uptake in nerve terminals were reduced in these identical tissue specimens $[15,16]$. Based on these observations, the cholinergic model of impairment was first presented in a review by Bartus et al. [17], which concluded that the critical event in the pathology of $\mathrm{AD}$ was the degeneration of the cholinergic connection from the nucleus of Meynert to the cortex and hippocampus [18].

$\mathrm{AD}$ is the most common neurodegenerative disorder that affects the elderly, resulting in memory loss and severe cognitive dysfunction [19]. The disease itself is complex but can be generally characterized by the following two main events in the brain: (1) aggregates of amyloid plaques (primarily composed of amyloid- $\beta$ peptide $[A \beta]$ ), and (2) neurofibrillary tangles formed via hyper-phosphorylated tau proteins [20]. $A \beta$ is generated by proteolytic cleavage of amyloid precursor protein (APP), which can be processed in two ways. A majority of APP undergoes cleavage by consecutive $\alpha$ (or $\gamma$ )-sectretases yielding soluble, non-pathogenic APP $\alpha$. Conversely, APP can be sequentially cleaved by $\beta$ (and $\gamma$ )-secretases to yield soluble APP $\beta$ and A $\beta$ (neurotoxic) [21]. A $\beta$ oligomer formation appears to affect hippocampal synaptic transmission, which is thought to be related to 
changes in synaptophysin expression and severely diminished ChaT transcription, leading to decreased ChAt activity and the steady progression of dementia [22].

In early efforts to improve cholinergic transmission and enhance cognitive function of AD patients, acetylcholinesterase (AChE) inhibitors (e.g., tacrine, physostigmine, donepezil, galantamine, rivastigmine) and directly acting agonists at postsynaptic muscarinic receptors in the cerebral cortex (e.g., arecoline, RS-86, and pilocarpine) (Figure 1) were utilized as a first-line treatment [23]. Of the aforementioned classes of compounds, the AChE inhibitors showed the greatest success in early clinical trials due, in part, to the side effects associated with non-specific $\mathrm{mAChR}$ stimulation via direct-acting agonists. While AChE inhibitors are still used today for symptom treatment, their efficacy is modest at best [24] and, thus, the cognitive symptoms of AD (e.g., memory loss, confusion, problems thinking/reasoning, etc.) are poorly managed. Additionally, cardiovascular and gastrointestinal side effects are often observed with these treatments (thought to be mediated by peripherally located ACh receptors), and beneficial effects tend to dissipate with tolerance $[25,26]$.

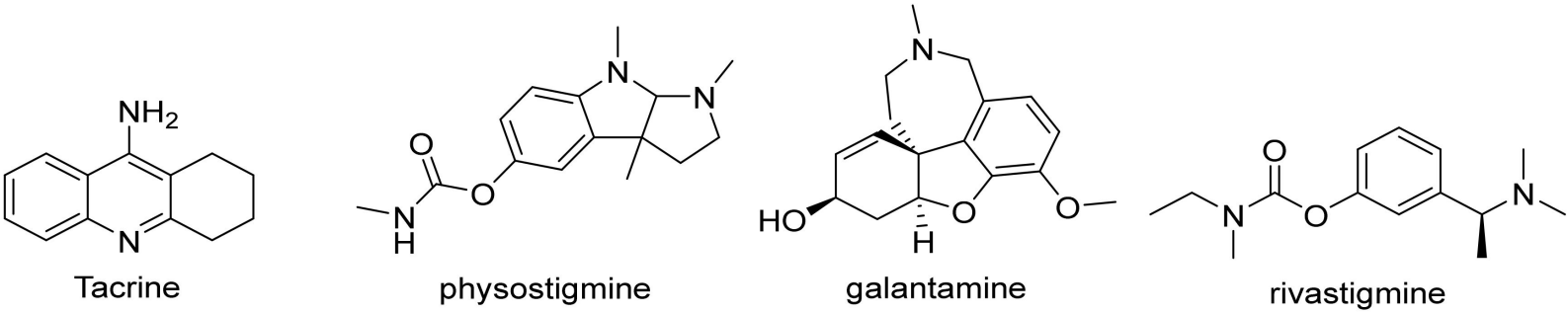<smiles>COc1cc2c(cc1OC)C(=O)C(CC1CCN(Cc3ccccc3)CC1)C2</smiles><smiles></smiles><smiles>[R5]c1ccc(C)cc1</smiles><smiles>CC[C@H]1C(=O)OC[C@@H]1Cc1cncn1C</smiles><smiles>Cc1noc(C2=CCCN(C)C2)n1</smiles><smiles>[Z]N1CCC=C(c2nc(N)no2)C1</smiles><smiles>Cc1noc(C2CN3CCC(C3)C2[R5]2CC3CCN(C3)C2c2nc(C)no2)n1</smiles><smiles>Nc1noc(C2CN3CCC(C3)C2c2nc(N)no2)n1</smiles>

Figure 1. AChEs and direct acting $\mathrm{mAChR}$ agonists (brackets).

Merck's early efforts to improve the clinical profile of arecoline, a weak partial agonist in the cortex compared to ACh, involved replacing the ester group (pink, Figure 1) with the metabolically stable 3-methyl-1,2,4-oxadiazole (red/green, Figure 1) bioisostere. The arecoline-based oxadiazoles $(1,2)$ demonstrated greater potency than arecoline itself but offered only minimal efficacy improvements, leading Merck to develop the quinuclidine (1-azabicyclo[2.2.2]octane) and azanorbornane (1-azabicyclo[2.2.1] heptane)-methyl and amino oxadiazoles $(3,4,5 \mathrm{a} / \mathrm{b}, 6 \mathrm{a} / \mathrm{b})$ [27]. Both showed marked improvements in potency and efficacy over the arecoline series. The 3-exo configuration of the azanorbornanes displayed superior potency and efficacy among the series, attributable to a lower steric demand on the binding surface within the active site. The amino oxadiazole (red/blue, 
Figure 1) proved to have the highest potency and predicted efficacy, presumably due to the oxadiazole ring's increased hydrogen bonding capabilities. These early efforts led to the creation of a library of $\mathrm{mAChR}$ agonists over the next few decades that permitted elucidation of structure-activity relationships (SAR) among orthosteric ligands.

It was demonstrated that increasing the conformational flexibility and bulk of the azacyclic ring reduced affinity compared to the more rigid arecoline, azanorbornane, and quinuclidine cores. Additionally, increasing the pKa of the hindered amine (i.e., enhancing its ability to become protonated once in the CNS, and hence mimic the quaternary nitrogen of $\mathrm{ACh}$ ) enhanced the affinity for the mAChRs [27]. Therefore, Merck chemists and others shifted their focus to arecoline-, quinuclidine-, and azanorbornane-core structures in all subsequent studies. While successful at developing some of the most potent non-quaternary agonists to date, the novel compounds provided little therapeutic benefit, due to doselimiting cholinergic side effects that likely reflected their lack of subtype selectivity.

Neurochemical examination of brain material from AD patients showed a loss of the presynaptic marker enzyme (e.g., loss of synaptic terminals), choline acetyltransferase, and $\mathrm{M}_{2}$ - but not the postsynaptic $\mathrm{M}_{1}$-mAChRs in various brain regions [28-30]. Hence, drug development efforts shifted in the early 1990s to the generation of functionally selective $\mathrm{M}_{1}$ agonists.

As is known, $\mathrm{M}_{1}$ is the most abundant of the five $\mathrm{mAChRs}$ in brain regions (particularly in the prefrontal cortex and hippocampus) involved in cognitive processes [31,32]. Pharmacological blockade [33,34] or genetic deletion [35] of $\mathrm{M}_{1}$ produces significant learning and memory disturbances, including deficits in social interaction, social discrimination, and working memory (i.e., radial arm maze test). As several groups have implicated the role of central mAChRs in cognitive processes [36-38] as well as in APP processing [39,40], it was reasonable to ask whether selective activation of $\mathrm{M}_{1}$ could enhance cognition and reverse learning and memory disturbances. Sauerberg et al. [41], and Ward et al. [42] were among the first to design $\mathrm{M}_{1}$ selective compounds of the 3-(1,2,5-thiadiazolyl)-1,2,5,6tetrahydro-1-methylpyridine and 3-pyrazinyl-1,2,5,6-tetrahydro-1-methylpyridine type. The hexyloxythiadiazole derivative, known as Xanomeline (thiadiazole moiety in blue, Figure 2), showed early promise as a potential treatment for AD. Binding studies showed that it was a subtype-selective $\mathrm{M}_{1}$ receptor agonist; however, other in vitro/in vivo functional studies suggest that the compound is better classified as a (slightly) subtype-selective $\mathrm{M}_{1} / \mathrm{M}_{4}$ agonist.

Xanomeline was found to improve psychosis and behavioral disturbances in those suffering from AD [43] and also had positive effects in schizophrenic patients [44]. Unfortunately, the drug's clinical use was limited by its side effect profile that included salivation, sweating, and gastrointestinal distress, all of which are likely attributed to the nonselective stimulation of other $\mathrm{mAChRs}$ (primarily $\mathrm{M}_{3}$ receptors) $[45,46]$. Although GI side effects were the culprit of the high drop-out rate within clinical trials $[47,48]$, the compound is now being co-administered with trospium chloride (a generic drug for overactive bladder) to counteract peripheral autonomic effects that caused earlier trials to cease. KarXT (Xanomeline tartrate and trospium chloride) is now in Phase 2 trials (NCT02831231) to treat the cognitive symptoms of SZ, psychosis, and agitation related to dementia, including AD, and as a non-opioid based therapy for forms of post-operative inflammatory and neuropathic pain (https:/ / karunatx.com/programs/; Accessed 29 November 2021).

Efforts to develop $\mathrm{M}_{1}$-selective ligands and lower efficacy partial agonists to prevent cholinergic side effects continued for several years but with limited success [49]. Tetrazole (red, Figure 2)/1,2,3-triazole scaffolds [50], oxime ether functionality (orange, Figure 2) [51,52], 4-thiazolidinone (gold, Figure 2), and ether linkages directly to functionalized pyrazine rings (green, Figure 2) were designed in an attempt to replace the 1,2,4-oxadiazole ring; ultimately leading to the development of the first generation of compounds (Tazomeline [53], Alvameline [54], Cevimeline [55], Milameline [56], NGX-267 [57], Talsaclidine [58], Sabcomeline [59], and WAY-132983 [60], Figure 2). All failed at some stage in clinical development. 


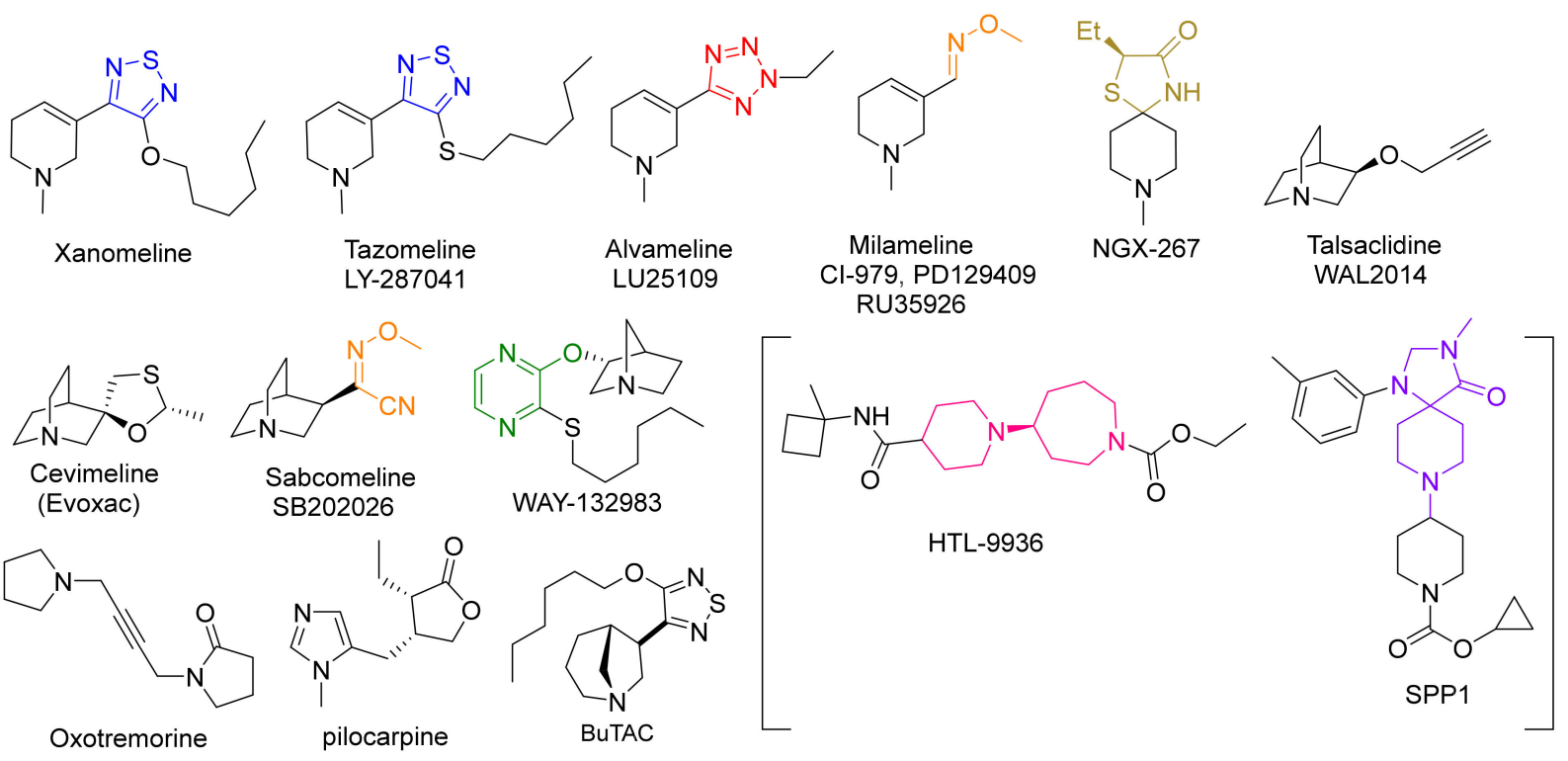

Figure 2. First generation of orthosteric mAChR agonists. HTL-9936 (Sosei Heptares, Phase 1 trials) and SPP1 (Eli Lilly, not yet in clinical development) represent recent efforts (brackets) targeting the $\mathrm{mAChRs}$ with functional selectivity for $\mathrm{M}_{1}$.

Despite recent efforts shifting to the design of highly selective allosteric modulators, Heptares Therapeutics (GPCR focused biotech, a subsidiary of Sosei) designed two highly selective $\mathrm{M}_{1}$ orthosteric agonists in phase 1 clinical development. Their proprietary approach incorporates the construction of stabilized $\mathrm{mAChRs}$ in their agonist conformations, followed by introducing mutations to allow for an improved stability of the mAChR in various conditions. These stabilized proteins permit crystallization with a wide selection of in-house and competitor ligands. The crystal structures generated in combination with site-directed mutagenesis allowed for the development of ligand binding models to the $\mathrm{M}_{1} \mathrm{mAChR}$, to which virtual screening could be applied to identify potential leads (StaR ${ }^{\circledR}$ technology) [61]. In 2016, Allergan acquired rights to develop further the muscarinic drug pipeline with the novel piperidinyl-azepine HTL-9936 (pink, Figure 1) and HTL-18318 (structure not published) as the lead candidates.

Additionally, HTL-9936 is a moderately efficacious partial agonist (45-75\% efficacy compared to $\mathrm{ACh}, \mathrm{EC}_{50} \sim 100 \mathrm{nM}$ ) at the $\mathrm{M}_{1} \mathrm{mAChR}$, displaying a modest selectivity ( 7fold) over $\mathrm{M}_{2}$ and two-fold selectivity for $\mathrm{M}_{1}$ over $\mathrm{M}_{4}$. Moreover, the molecule did not display functional agonist activity for human $\mathrm{M}_{2}$ and $\mathrm{M}_{3} \mathrm{mAChRs}$. Consistent with its in vitro profile, this compound was able to reverse a scopolamine-induced deficit in a passive avoidance task in rats and showed efficacy in rodent novel recognition and aged Beagle dog object retrieval tasks [62]. Heptares announced positive phase $1 \mathrm{~b}$ results (no adverse events or GI distress) in early 2016 (NCT02291783); however, more recent data has not yet been published. As noted by Felder [63], brain penetration was predicted to be low compared to plasma, and indeed, as indicated by a $\mathrm{Kp}_{\mathrm{u}, \mathrm{u}} \sim 0.05$ (generated by Lilly), brain exposures are anticipated to be approximately 20 -fold lower than plasma values. In general, $\mathrm{Kp}_{\mathrm{u}, \mathrm{u}}$ values of $\sim 0.3$ or greater are considered to have sufficient access to the CNS, with values greater than 1 representing compounds that freely cross the BBB (for review see Kulkarni et al. [64]. Kp $p_{u, u}$ represents the free fraction of the drug in the brain divided by the free fraction of drug in the plasma. The above data were calculated $30 \mathrm{~min}$ after oral dosing at $100 \mathrm{mg} / \mathrm{kg}$ using measured rat plasma and rat brain fraction unbound. Despite the low $\mathrm{Kp}_{\mathrm{u}, \mathrm{u}}$ value, it is likely sufficient for efficacy due to the high receptor reserve (i.e., activation of a fraction of receptors is sufficient for a full cellular response-see Schrage et al. [65], Rajagopal et al. [66], and Buchwald [67] for review) within the areas of the brain related to cognition. 
Little has been published on HTL-18318, which is also derived from Sosei Heptares' proprietary StaR technology (detailed above) and has a structure-based drug design. HTL18318 is a potent $M_{1}$ agonist with negligible activity at $M_{2} / M_{3}\left(M_{4} / M_{5}\right.$ not specified) that has undergone a phase I clinical trial for AD in the United States (NCT03456349) and a phase II trial in patients with Lewy body dementia in Japan (JapicCTI-183989). The compound has been investigated in over 300 human subjects (in both the US and Europe), including healthy volunteers and those with mild to moderate AD, with no serious adverse effects up to 28 days post-treatment. In a press release by Sosei Heptares in 2018, their upcoming Phase 2 clinical trial (JapicCTI-183989) had been voluntarily halted due to a single animal toxicology study (non-human primates) investigating dosing levels of this compound over nine months. In their statement, some animals developed tumors, albeit at doses higher than those expected to be used in humans, thereby causing further development (including a planned Phase 2 study for AD) to be suspended [68].

While there was no publication by Sosei Heptares detailing the results of the abovementioned dosing study, the clinical evaluation of HTL-18318 continued in Europe. In one study, a randomized, double-blind, placebo-controlled study in 40 healthy young adults and 57 healthy elderly subjects showed that the compound [1-35 mg, administered PO] was absorbed rapidly (peak concentration after $1-2 \mathrm{~h}$ ) and had a half-life of $\sim 12-16 \mathrm{~h}$. More importantly, while approximately $30 \%$ of the plasma unbound concentration entered the cerebral spinal fluid, single doses were associated with only mild dose-related adverse effects (hyperhidrosis, slight increases in blood pressure), yet no statistically significant effects on cognitive function [69]. In a follow-up study, treatment with HTL18318 over ten days displayed significant improvements in tests of short-term working memory (n-back test) and learning (Milner maze) (NTR5781) [70].

While ligands such as HTL18318 may generate some optimism, drug design targeting the orthosteric site for AD treatment continues to be challenging for academics and industry alike, which can be attributed to the highly homologous binding pocket of the mAChRs. Additionally, as $\mathrm{ACh}$ is a permanent cation, it presents a unique problem for designing (and modeling) an orthosteric agonist that effectively penetrates the CNS, while possessing a sufficiently basic moiety to allow for protonation, hence mimicking the cationic nature of ACh. Nevertheless, advances in VS (Virtual Screening)/high throughput screening (HTS) and crystallization techniques have made it possible to target the orthosteric site with some degree of functional selectivity. The essential feature appears to be the delicate balance between brain penetration and partial-agonist-like efficacy profile to minimize peripheral AEs and $M_{1}$ mediated adverse effects. While not yet applied in clinical trials, the most recent advancement has come from Eli Lilly in late 2018 in the form of SPP1 (Figure 1), a selective $M_{1}$ partial agonist based on a spiro-piperidine core (similar to AZD-6088), which showed $>100$-fold functional selectivity versus $\mathrm{M}_{2} / \mathrm{M}_{3}$ (a clear improvement over HTL-9936) [71,72]. Significantly, these successful efforts demonstrate that high sequence homology need not preclude the development of orthosteric compounds and indicate that the field remains open for continued exploration.

\subsection{Allosteric Modulators}

Since the discovery of gallamine as an allosteric modulator by Clark and Mitchelson [69], considerable effort has been directed to understanding its mechanism. HTS capabilities, high-resolution crystal structures (with and without allosteric modulators bound), and powerful computational simulation capabilities have paved the way for identifying several diverse chemical scaffolds that display high functional selectivity. $\mathrm{M}_{1}$ continues to be the target of choice for AD due to its alleged vital role in cholinergic deficit, cognitive dysfunction, and tau/A $\beta$ pathologies $[39,73,74]$.

The difficulty of obtaining a high degree of functional selectivity targeting the orthosteric site has led researchers to focus on allosteric ligands, which target less conserved receptor regions (e.g., ECLs). Mechanistically this may reflect several advantageous considerations. For example, modulators can be identified with higher affinity for one subtype 
over others because of lower sequence conservation in allosteric sites. Additionally, subtype selectivity can also arise from cooperativity or, in the case of 'absolute subtype selectivity', both cooperativity and affinity [75]. Furthermore, an allosteric effect only arises when the endogenous ligand ( $\mathrm{ACh}$ ) is present and, therefore, better mimics the physiological regulation of receptor activity (e.g., enhances cholinergic tone) [8]. Finally, allosteric actions are saturable (exhibit a "ceiling" effect) [76], which allows for a wider safety margin (e.g., less adverse side-effect profile).

The first and most often studied allosteric modulators of the mAChRs were the neuromuscular blocking agents (gallamine/alcuronium) and a series of alkyl-bis-quaternary ammonium compounds (Obidoxime/C7/3-phth/W84, pink, Figure 3) [77,78]. Alcuronium was found to be the first allosteric enhancer of the binding of an orthosteric $\mathrm{mAChR}$ ligand $[79,80]$, and was shown to bind at the same site as gallamine and the alkyl-bisquaternary ammonium compounds [81]. A second allosteric site was identified shortly thereafter through the observation that derivatives of staurosporine (a nonselective kinase inhibitor) exhibited positive, negative, or neutral cooperativity but did not bind to the already known allosteric site (e.g., that of gallamine and brucine, Figure 3) [82].

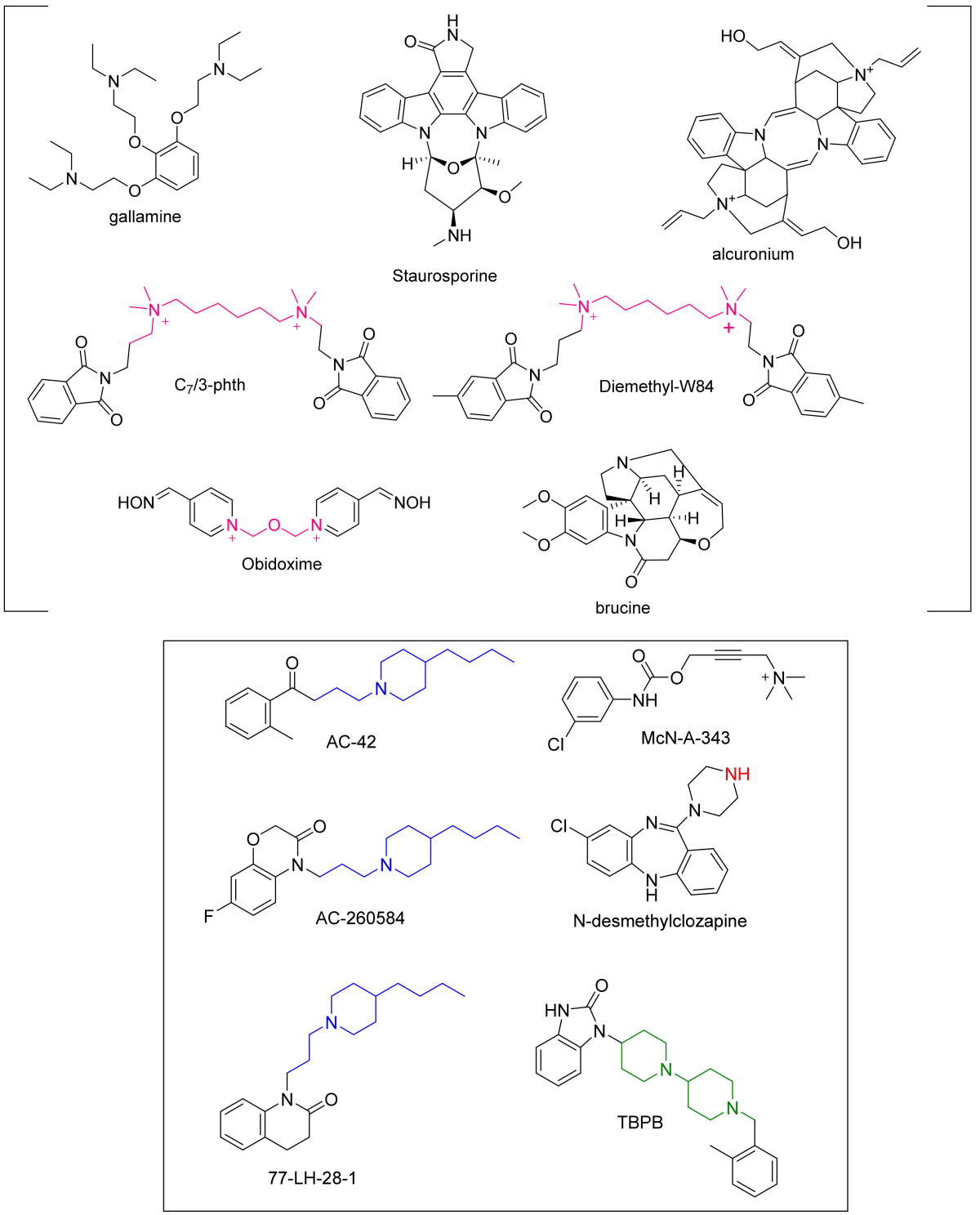

Figure 3. Neuromuscular blocking agents and bis-quaternary ammonium compounds (brackets). First generation of allosteric modulators (box). 
Furthermore, McN-A-343 [83-85], AC-42 (Acadia Pharmaceuticals, Inc., butyl piperidine core, blue, Figure 3) [84], AC-260584 [86-89], 77-LH-28-1 (GSK, Figure 3) [90], and TBPB (bis-piperidinyl core, green, Figure 3) [40,91], were among the first generation of allosteric modulators (for review see Conn et al. [92] and Heinrich et al. [60]). However, they suffered drawbacks from lack of selectivity and efficacy in vivo, off-target effects, intrinsic activity, and unsuitable PK properties, which prevented their further development for clinical use.

Merck's first prototypical $\mathrm{M}_{1}$ PAM, benzyl quinolone carboxylic acid (BQCA, and derivatives, Figure 4), was a highly selective potentiator $\mathrm{M}_{1}$ receptor while demonstrating no action at any other subtype (up to $100 \mu \mathrm{M}$ ). It reduced scopolamine-induced memory deficits in contextual fear conditioning (CFC) assays, restored discrimination reversal learning in a transgenic mouse model of AD, regulated amyloidogenic APP processing in vitro, and reversed amphetamine-induced hyperlocomotion, which is an in vivo assay of antipsychotic efficacy) $[92,93]$. While the compound's low efficacy precluded its ascension to clinical trials, the scaffold was optimized for safety and bioavailability, which led to more successful derivatives [94-99].<smiles>COc1ccc(Cn2cc(C(=O)O)c(=O)c3ccccc32)cc1</smiles>

BQCA

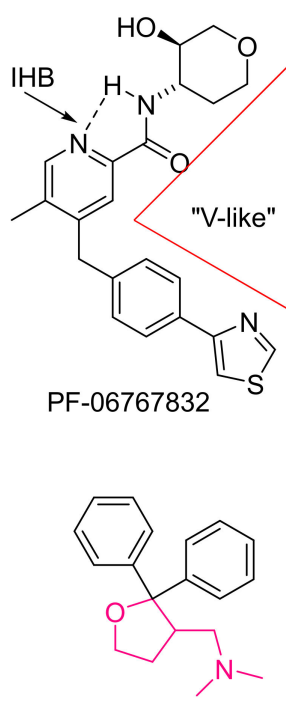

ANAVEX2-73

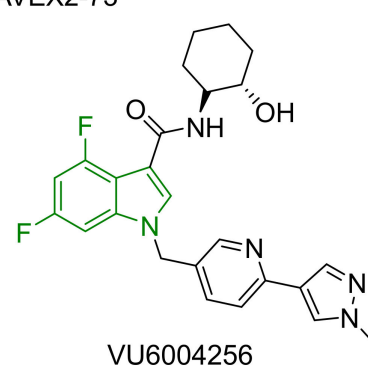<smiles>N#CC1(c2ccccn2)CCN(Cc2cc(C(=O)O)c(=O)n3ccccc23)CC1</smiles><smiles>Cc1ccc(Cc2cc3c(=O)n([C@@H]4CCCC[C@H]4O)cnc3c3ccccc23)cn1</smiles><smiles>Cc1c(Cc2ccc(-n3cccn3)cc2)cc2c(c1F)CN([C@@H]1COCC[C@H]1O)C2=O</smiles>

PF-068274430

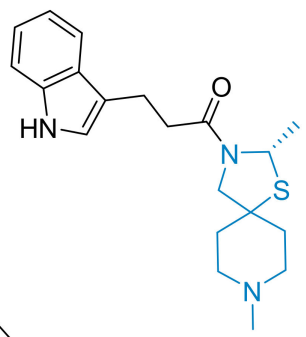

ANAVEX 3-71 (formerly AF710B)
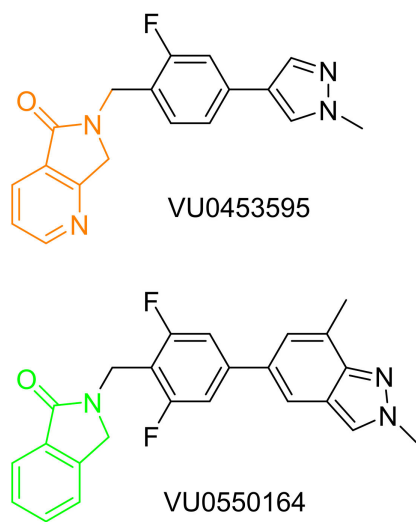

Figure 4. Recent designs of allosteric modulators (primarily) targeting the $\mathrm{M}_{1}$ receptor. 
Additionally, MK-7622 (Merck) represented a first-in-class allosteric modulator optimized from the BQCA core scaffold. While BQCA (and subsequently 1-((4-cyano-4(pyridine-2-yl)piperidin-1-yl)methyl-4-oxo-4H-quinolizine-3-carboxylic acid, PQCA) was useful in probing the pharmacological effects of allosteric modulation, low CNS penetration, and rapid efflux out of the CNS via the phospho-glycoprotein (P-gp) transporter resulted in poor efficacy. Replacing the carboxylic acid group of BQCA/PQCA through introducing a pyrimidinone ring (blue, Figure 4) appeared to offer a balance between low P-gp efflux and good oral bioavailability, and clinical efficacy. P-gp is likely the most well-known of the ABC (ATP-binding cassette) superfamily that acts as an efflux pump with broad substrate specificity - albeit it has been shown to preferentially extrude large, hydrophobic, positively charged molecules [100-102]. It is expressed in a variety of tissues (e.g., GI tract, kidney, liver, endothelium, etc.), including a continuous single layer of brain capillary endothelial cells with tight junctions [103]. There is a clear relationship between P-gp efflux and brain exposure, therefore, a P-gp screening assay is imperative for CNS drug discovery programs. The brain-to-plasma concentration ratio $(\mathrm{Kp}$,brain $)$ and the unbound brain-to-plasma concentration ratio $\left(\mathrm{Kp}_{\mathrm{u}, \mathrm{u}}\right.$, mentioned above) are most commonly used as in vivo PK parameters to assess brain penetration of a compound. While both in vitro and in vivo assays are used in drug discovery, there is often a lack of correlation between the two, likely due to differential expression of P-gp in different cell lines. Therefore, it is preferable to calculate these PK parameters using in vivo experiments in rodents-despite the inherent limitation that differences in P-gp expression or in transport potentials of substrates across species likely exist [104]

Furthermore, MK-7622 was shown to reverse scopolamine's effects at $3 \mathrm{mg} / \mathrm{kg}$ in a mouse contextual fear conditioning assay [100]. Merck began a Phase 2 trial in 2013 to evaluate the compound's tolerability and efficacy as a symptomatic adjunct to donepezil therapy. The trial was expected to enroll 830 patients but was terminated in 2016 after enrolling only 240 participants. A futility analysis indicated that 12 weeks of treatment with MK-7622, given in combination with AChE inhibitors, did not improve cognition in patients with mild/moderate AD (NCT01852110) [105]. These disappointing results were suggested to have reflected the compound's ability to activate $\mathrm{M}_{1} \mathrm{mAChRs}$ in the absence of ACh (intrinsic activity), thereby disrupting prefrontal cortex (PFC) function [106,107].

Davoren et al. [32] (Pfizer) disclosed a series of PQCA derivatives based on the truncation of the quinolizinone core (green, Figure 4) and installation of the 5-methyl group on the pyridine ring to retain the optimal geometry of the benzyl group (V-shaped, or "bent," conformation) and intramolecular hydrogen bond. After optimization, they arrived at PF-06767832, which displayed 180-fold selectivity for $\mathrm{M}_{1}$ over $\mathrm{M}_{2-5}$ with no observed off-target effects and high cooperativity with $\mathrm{ACh}\left(\alpha \beta\right.$ value $=126$, intracellular $\mathrm{Ca}^{2+}$ assays). In vivo, this molecule reversed amphetamine-stimulated locomotor activity and ameliorated scopolamine-induced deficits in spatial learning and memory in the Morris water maze [32]. At low concentrations, it acted as an $\mathrm{M}_{1} \mathrm{PAM}\left(\mathrm{EC}_{50}=60 \mathrm{nM}\right)$ but, at higher concentrations, it displayed intrinsic agonist activity, which led to adverse cholinergic AEs that, depending on dosage and regimen, progressed from GI disturbance to generalized convulsions [32,106,107]. These negative results led to the development of PF-068274430, a covalently constrained ( $\gamma$-lactam, purple, Figure 4) derivative of PF-06767832, that was reported to have a lower intrinsic agonist activity and cooperativity score $(\alpha \beta=70$, intracellular $\mathrm{Ca}^{2+}$ assay). Nevertheless, this compound also produced AEs at elevated doses, precluding its development in the clinic.

Other companies, namely Asceneuron (a subsidiary of Merck, WO2014198808), Roche (WO2015028483), and Takeda (WO2016208775, TAK-071, Figure 4), also have projects dedicated to $\mathrm{M}_{1}$ PAM development, with TAK-071 being the only compound to have reached clinical trials. Research groups, including those led by Jeffrey Conn and Craig Lindsley at Vanderbilt, were among the first to report the development of highly selective $\mathrm{M}_{1}$ PAMs [92], discoveries that led to the development of the Warren Center for Neuroscience Drug development Discovery (WCNDD, wcndd.com; Accessed 01 December 2021) and a 
vast library of allosteric agonists, $\mathrm{M}_{1}$ PAMs, and antagonists (see review by Kuduk and Beshore [108] and, more recently, Wold et al. [109]).

More recent efforts include novel M 1 PAMs, VU0453595 (6,7-dihydro-5H-pyrrolo[3,4b]pyridine-5-one core, orange, Figure 4) and VU0550164 (isoindolin-1-one core, light green, Figure 4), which were shown to lack constitutive agonist activity in cell lines and maintain activity dependence of $\mathrm{M}_{1}$ activation in the PFC. Moreover, unlike MK-7622, VU0453595 did not induce behavioral convulsions, even at doses well above that required to improve cognitive function [110]. These pivotal findings support the conclusion that the in vivo cognition-enhancing efficacy of $\mathrm{M}_{1}$ PAMs without intrinsic activity is possible and, additionally, may provide a more favorable side-effect profile. Since these findings, further optimization of the PK/PD properties of the core scaffolds has further improved levels of CNS penetration ( $\mathrm{K}_{\mathrm{p}} \mathrm{s} 0.30-3.1$, see Panarese et al. [111]).

Moreover, VU319 (structure not published) is perhaps the most successful novel $\mathrm{M}_{1}$ PAM to emerge from Vanderbilt's efforts. The compound underwent a phase 1 clinical trial in 2017 to establish safety and tolerability and to characterize its PK/PD profile (NCT03220295). Currently, no results have been posted for this trial. However, results were presented at the 2020 Alzheimer's Association International Conference (AAIC) annual meeting, indicating that VU319 demonstrated a safe profile and, based on cognitive performance and EEG measures of event-related potentials, enhanced cholinergic function $[112,113]$. The group also reported an absence of documented dose-limiting cholinergic adverse effects. Although a firm evaluation can only be provided once the results are published, these reported findings are consistent with the idea that VU319 displays high functional selectivity for the $\mathrm{M}_{1} \mathrm{mAChR}$ (and low intrinsic activity). A second Phase 1 trial was initiated in Fall 2019 (NCT04051801) to establish the maximum tolerable dose of VU319 and, presuming its profile remains favorable, it is likely that VU319 soon will be evaluated in a multiple ascending dose study as well as a Phase 2a proof of concept trial in patients with mild cognitive impairment. The latter studies will be especially interesting, as they will speak directly to the clinical value of allosteric modulation of $\mathrm{M}_{1}$ receptors.

In 2015-2016, Anavex Life Sciences, a biopharmaceutical company developing drug candidates for AD and other CNS diseases, unveiled both ANAVEX 2-73 (blarcamesine) [114] and ANAVEX 3-71 (previously known as AF170B) (Figure 4). 2-73 is a novel aminotetrahydrofuran (pink, Figure 4) derivative that is a mixed agonist of the chaperone protein sigma-1 $\left(\mathrm{IC}_{50}=0.86 \mu \mathrm{M}\right)$ and the $\mathrm{M}_{1-4}$ receptors $\left(\mathrm{IC}_{50}=3.3-5.2 \mu \mathrm{M}\right)$ [115]. The compound (0.01-3.0 $\mathrm{mg} / \mathrm{kg}$ i.p.) was shown to alleviate scopolamine and dizocilpine-induced learning impairments and reverse learning deficits $(300 \mu \mathrm{g} / \mathrm{kg})$ in mice injected with synthetic $A \beta\left(A \beta_{25-35}\right)$ oligomer (likely via inhibition of $A \beta_{25}-35$-induced oxidative stress in the hippocampus) [114-116]. Subsequent studies by Lahmy et al. $[115,117]$ suggested that the compound may block tau hyperphosphorylation and amyloid- $\beta 1-42$ in an $A \beta_{25-35}$ mouse AD model. On the basis of these findings, a Phase 2b/3 (NCT03790709) clinical trial was undertaken and recently completed the enrollment of patients $(n=509)$ with mild-to-moderate AD to evaluate the effects of ANAVEX 2-73 on cognition and function (ADCS-ADL) after 48 weeks of daily treatment. Although ANAVEX 2-73 was initially designed to treat AD (i.e., cholinergic hypofunction), it is also undergoing a Phase 2 evaluation of its efficacy in treating Parkinson's disease dementia (i.e., cholinergic hyperfunction) (NCT03774459) and Rett Syndrome (NCT03941444 and NCT04304482, Kaufmann et al. 2019). These latter studies are likely designed to evaluate ANAVEX 2-73's activity at the sigma-1 receptor. Thus, activation of sigma-1 mechanisms has been shown to result in lower toxic accumulation of misfolded proteins in nerve cells, dysfunction in mitochondria, oxidative stress, and neuroinflammation, all of which are involved in Parkinson's, AD, and Rett syndrome. Of interest, early results of the PDD trial, presented in 2020, suggested that treatments with 30 or $50 \mathrm{mg}$ daily for 14 weeks resulted in improvements in memory and attention measures compared to placebo. To explore these effects further, the trial currently has an open-label extension [118]. 
With regard to ANAVEX 3-71 (Figure 4), it shares some structural similarities with the early orthosteric agonist NGX267 (Figure 1) but displays a strikingly different pharmacological and binding profile. Similar to 2-73, it is a chiral (S-enantiomer, US8673931B2), highly selective mixed sigma-1 $(0.25 \mu \mathrm{M})$, and $\mathrm{M}_{1}\left(41 \mu \mathrm{M}\right.$, no agonistic activity at $\mathrm{M}_{2^{-}}$ $\mathrm{M}_{5}$ ) PAM, with no appreciable off-target activity. Moreover, the compound effectively reversed cognitive deficits induced by trihexyphenidyl (1-30 $\mu \mathrm{g} / \mathrm{kg})$, decreased tau phosphorylation induced by $\mathrm{A} \beta_{25-35}$, exerted neuroprotective effects (low $\mu \mathrm{M}$ ), and rescued mushroom spines in hippocampal neuron culture from PS1.KI and APP.KI mice [119]. The (S)-enantiomer of this molecule is in Phase 1 trials for safety, tolerability, and PK (NCT04442945). Interestingly, the (R)-enantiomer is inactive up to $10 \mu \mathrm{g} / \mathrm{kg}$ p.o., indicating that the effects of AF710B on cognition are enantioselective.

Marketed as a highly selective $\mathrm{M}_{1}$ PAM with a lower $\alpha$-value ( 199), TAK-071 (Takeda Pharmaceutical Company Ltd, Osaka, Japan), shows some similarities in structure to VU055064 (isoindolin-1-one core, green). The compound was shown to improve scopolamine-induced cognitive deficits in rats $(0.3 \mathrm{mg} / \mathrm{kg})$ with a reduced side effect profile (GI distress tolerable up to $10 \mathrm{mg} / \mathrm{kg}$ ) [120]. Additionally, it induced afterdepolarization in layer V pyramidal neurons and, when combined with AChEIs, it exhibited synergistic effects in reversing scopolamine-induced deficits in the novel object recognition task. The compound entered Phase 1 trials in 2016 to identify a safe and well-tolerated dose (NCT02769065) and shortly thereafter to evaluate its ability to ameliorate cognitive impairments induced by scopolamine (in combination with donepezil) (NCT02918266). Both sets of trials were terminated early on due to indication change, and TAK-071 is currently being evaluated for its effects on falls in patients with Parkinson's disease (NCT04334317).

Given the high homology of the orthosteric site, it is not surprising that most recent efforts have shifted to targeting the less conserved allosteric binding regions in the ECLs of the mAChRs. Additionally, PAMs seem to offer an advantage to direct acting agonists by enhancing cholinergic tone via modulating the effects of natural neurotransmitters, and hence better mimics physiological receptor activity, much progress has been made through modeling, virtual screening, and SBDD in developing functionally selective compounds for the $\mathrm{M}_{1} \mathrm{mAChR}$. However, more work is needed to establish optimal doses that preserve efficacy yet produce minimal side effects and, more generally, to better understand how occupancy of the mAChRs translates to efficacy over time and dose. For example, at what stage of AD would an agonist (or PAM) provide the best symptom relief? While there are still many unanswered questions, a few critical features of successful mAChR PAMs do appear to be consistent: (1) low cooperativity (e.g., low $\alpha$-values); (2) low intrinsic activity; (3) and most importantly, high functional selectivity, appear to be essential factors for mAChR PAMs (or agonists) that have meaningful efficacy and are devoid of unendurable AEs.

\section{Drug Design Targeting the mAChRs: Schizophrenia}

Schizophrenia is a chronic, disabling brain disorder affecting $\sim 1 \%$ of the population (hhs.gov accessed on 15 December 2021) with multiple symptoms, some of which overlap with AD. The term schizophrenia comes from the Greek for "splitting of the mind [121]". The onset of these markedly variable symptoms typically occurs early in life (e.g., <30 years of age), between adolescence and young adulthood, and has been hypothesized to be instigated by factors that are not well understood [122]. Characteristic symptoms include the positive cluster, including hallucinations, delusional thoughts/beliefs, and difficulty concentrating and speaking. Negative symptoms, which have not been well-targeted to date in the development of novel antipsychotics include anhedonia, dysfunctional social interactions, loss of interest in everyday life activities, and cognitive disruptions affecting several aspects of daily living (e.g., executive functions) $[123,124]$. It should be noted that while many AD symptoms are cognitive in nature (learning and memory), a large portion of AD patients (50-80\%) also show psychotic and behavioral disturbances that correlate to poor social and functional outcomes similar to SZ [125]. 
Although the causes of the disease remain largely unknown, most of the research over the past few decades has targeted the dysregulation of the signaling by monoamines (e.g., dopamine and serotonin). The dopamine hypothesis of SZ (for review, see Carlson [126]) proposes that positive symptoms correlate with hyperdopaminergic activity in the striatal and mesolimbic pathways. In contrast, negative symptoms are related to hypodopaminergic activity in the medial prefrontal and mesocortical pathways [127-130]. This has been confirmed through positron emission tomography (PET), which showed that SZ patients had increased synaptic dopamine levels, released higher levels of dopamine in response to amphetamines, and an increased basal level of dopamine synthesis [131]. Current antipsychotics effectively treat positive symptoms but do not address the flattened affect, social withdrawal, working memory deficits, and cognitive flexibility [132]. Unfortunately, prescription treatments are commonly discontinued due to the extrapyramidal symptoms that patients experience (dystoria, akathisia, parkinsonism, bradykinesia) from first-generation treatments or metabolic side effects (e.g., weight gain, type II diabetes, hyperlipidosis) from second-generation atypical antipsychotics $[133,134]$. Therefore, given the detrimental consequences of the negative and cognitive symptoms of the disease, therapeutic strategies that move beyond $\mathrm{D}_{2}$ antagonism are needed.

While the dopamine hypothesis of SZ served to introduce several generations of antipsychotic medications, it has long been recognized that dopamine hyperactivity alone cannot account for the wide range of positive, negative, and cognitive symptoms experienced by patients $[135,136]$. For example, in recent years, intriguing hypotheses have been presented by several groups concerning the role of post-synaptic density (PSD) proteins and their relationship to glutamatergic signaling in SZ. These proteins are a part of a specialized complex located at excitatory glutamatergic post-synaptic terminals, that contain NMDARs, membrane channels, scaffolding and signaling proteins, GTPases, kinases, and regulator proteins, among others that are implicated in synaptic plasticity [137]. Within the postsynaptic density region, tuning of downstream glutamatergic neurotransmission occurs, which allows for cross-talk between other neurotransmitter signaling pathways [138]. As multiple postsynaptic signaling pathways within this region of the neuron are involved in the transduction of glutamatergic and other postsynaptic signals, defects in these proteins (or disruption of protein clusters) may be implicated in SZ and other developmental disorders (e.g., autism, mood disorders_for a recent review see de Bartolomeis et al. [139]).

Additionally, the psychotomimetic effects of NMDA/mAChR receptor antagonists, growing evidence that inhibitory GABA signaling is dysregulated in SZ patients (particularly in the cortex) [140-146], and the recognition that all three signaling pathways can be modulated through the activation of the cholinergic system has renewed interest in designing modulators of the mAChRs and nAChRs (for review of nAChRs see Taly et al. [147]). Since AChEIs have demonstrated therapeutic efficacy in mediating cognitive deficits in AD patients, it has been suggested that AChEIs might be effective as a supplementary medication in SZ patients [148,149]. However, clinical trial results have been disappointing due to dose-limiting cholinergic side-effects (primarily mediated by stimulation of the $\mathrm{M}_{2}$ and $\mathrm{M}_{3} \mathrm{mAChRs}$ ) of traditional non-selective cholinergic therapies $[150,151]$.

Current strategies for targeting the mAChRs in the treatment of SZ are based on some key observations: 1) $\mathrm{M}_{1}$ and $\mathrm{M}_{4} \mathrm{KO}$ mice exhibit a dopamine hypersensitivity phenotype [7], i.e., they are hyperactive compared to wild-type, and this effect is greater in $M_{1}$ than $M_{4}$ $\mathrm{KO}$ mice) [7,152-154]. Gerber et al. [155] reported that $\mathrm{M}_{1} \mathrm{KO}$ mice displayed a significant increase in extracellular dopamine concentrations in the striatum, resulting in increased locomotor activity. These mAChRs are also usually responsible for regulating excitatory cholinergic flow to midbrain dopaminergic neurons [156]. This evaluation of hyperactivity derives from: (1) microdialysis studies showing that psychostimulants ( $d$-amphetamine and phencyclidine) enhance dopamine efflux within the nucleus accumbens (nAcc) in the absence of $\mathrm{M}_{4} \mathrm{mAChRs}$; (2) postmortem studies (brain-tissue) indicated a reduction in expression levels of both $\mathrm{M}_{1}$ and $\mathrm{M}_{4} \mathrm{mAChRs}$ caudate, putamen, hippocampus, cingulate cortex and the prefrontal cortex in SZ patients [135,157]; and (3) the $\mathrm{M}_{4}$ receptor is highly 
coexpressed with the $D_{1}$ receptor [158]. Thus, when an agonist (e.g., oxotremorine) is administered to these neurons, a decrease in dopamine-stimulated cAMP is observed due to cross-talk between the $\mathrm{D}_{1} / \mathrm{M}_{4}$ receptors. cAMP signaling is activated (by dopamine) via the $G \alpha_{\mathrm{s}}$-coupled $\mathrm{D}_{1}$ dopamine receptor, and $A C h$ inhibits cAMP production via the $\mathrm{G} \alpha_{\mathrm{i} / \mathrm{o}}$-coupled $\mathrm{M}_{4}$ receptor in a complex push-pull mechanism [159]. These results suggest that both $\mathrm{M}_{1}$ and $\mathrm{M}_{4} \mathrm{mAChRs}$ play a role in controlling dopamine signaling in key regions of the brain and can be linked to increased locomotor activity in mice.

As drug development efforts to identify new mAChR subtype-selective ligands (specifically for $\mathrm{M}_{1}$ and $\mathrm{M}_{4}$ ) became possible, a number of studies using postmortem tissue (for review, see Hopper et al. [160]) reported decreased binding densities with $\left[{ }^{3} \mathrm{H}\right]$-pirenzepine ( $\left.\left[{ }^{3} \mathrm{H}\right] \mathrm{PRZ}\right)$, a selective $\mathrm{M}_{1} / \mathrm{M}_{4}$ antagonist, in the cortex, hippocampus, and striatum in SZ patients [161-164]. The link between decreased receptor densities was further strengthened by neuroimaging data showing a decrease in $\mathrm{mAChR}$ binding potential in patients not taking antipsychotic medication at the time of imaging [165]. Importantly, the decreased cortical binding levels that were evident in SZ patients were not evident in patients diagnosed with MDD, bipolar disorder (BPD), AD, or Parkinson's disease [166]. Finally, the use of receptor-specific antibodies in immunopharmacological experiments and the quantification of mRNA levels in molecular biology experiments provided additional evidence of decreased levels of both $\mathrm{M}_{1}$ receptors in the dorsolateral prefrontal cortex and $\mathrm{M}_{4}$ receptors in the hippocampus in SZ patients $[167,168]$. In conjunction with subsequent reports of SZ-specific CHRM1 $\left(\mathrm{M}_{1}\right)$ and CHRM4 $\left(\mathrm{M}_{4}\right)$ polymorphisms, the above findings suggest that the disease and its distinguishing phenotype might be linked to a decrease in $\mathrm{M}_{1} / \mathrm{M}_{4}$ function $[169,170]$. This possibility has driven the strategy of stimulating the $\mathrm{M}_{1} / \mathrm{M}_{4}$ receptors as a means of alleviating the negative symptoms of SZ.

It should be mentioned that $\sim 25 \%$ of SZ patients have shown a reduction of up to $75 \%$ of normal $\mathrm{M}_{1}$ receptor expression in the prefrontal cortex (Brodmann area 9, BA9) when compared to non-SZ controls [156,171-173]. SZ patients with this reduced expression of $\mathrm{M}_{1} \mathrm{mAChRs}$ have been characterized as having "muscarinic receptor-deficit syndrome" (MRDS). Dean et al. [156] and Hopper et al. [174] identified this phenomenon in binding experiments with $\left[{ }^{3} \mathrm{H}\right]-\mathrm{N}$-methyl-scopolamine $\left(\left[{ }^{3} \mathrm{H}\right]-\mathrm{NMS}\right)$ and BQCA, showing that the ability of BQCA to modulate the displacement of $\left[{ }^{3} \mathrm{H}\right]-\mathrm{NMS}$ by acetylcholine was reduced in MRDS tissues, which is similar to the decrease in cortical $\mathrm{M}_{1}$ receptors in SZ MRDS patients. This finding is clinically relevant and suggests that treating such SZ patients with $\mathrm{M}_{1}$ selective ligands may not be therapeutically advantageous, as the desired effect could be absent due to low CHRM1 levels. While this idea is speculative, it illustrates the types of challenges to the successful development of novel therapeutics for the treatment of the varied symptomology-positive, negative, and cognitive-that must be faced in undertaking such efforts.

\subsection{Orthosteric Agonists}

Drugs that activate the $\mathrm{M}_{4} \mathrm{mAChR}$, albeit without appreciable subtype selectivity, are currently being utilized in the treatment of SZ. This strategy was introduced with the evaluation of Xanomeline, a partial agonist at the $\mathrm{M}_{1} / \mathrm{M}_{4}$ subtypes of $\mathrm{mAChRs}$, as a treatment medication in SZ patients [175]. As noted above, dose-limiting side effects of Xanomeline (GI distress, likely due to agonism at peripheral mAChRs) limited its clinical effectiveness for the treatment of AD patients. Despite such setbacks, the success of Xanomeline in reducing behavioral disturbances and its positive effects on cognition warranted a small follow-up phase II trial [44]. Following two weeks of treatment, patients (who discontinued antipsychotic medication during the trial) showed significant improvements in the Brief Psychiatric Rating Scale (BPRS), Positive and Negative Syndrome Scale (PANSS), and Clinical Global Impression Scale, when compared to the placebo-controlled group. Again, as with the AD study [43], the side effects halted further clinical development. Renewed interest in Xanomeline (Figure 1) emerged from Karana Pharmaceuticals advancement of KarXT, a combination of Xanomeline and a peripherally restricted $\mathrm{mAChR}$ antagonist 
trospium chloride (to mitigate the adverse peripheral side effects of Xanomeline), which recently completed Phase II trials for SZ (NCT03697252) with promising results in the Positive and Negative Syndrome Scale (PANSS). The dose selected for the study (125 mg Xanomeline/30 mg trospium chloride) still produced cholinergic and anticholinergic sideeffects [176,177]; nevertheless, Phase 3 clinical trials are now underway to evaluate efficacy, safety, and long-term safety and tolerability of KarXT in adult SZ patients (NCT04659161; NCT04738123; NCT04659174; NCT04820309). Large-scale clinical studies are still needed to fully determine the efficacy of KarXT; notwithstanding this caveat, the development of Xanomeline, though challenging, represents a novel therapeutic strategy for the treatment of SZ.

Although little attention has been given to further advancing orthosteric $\mathrm{M}_{4}$ agonists, the drug development division of Sumitomo Dainippon Pharma in Japan published recent progress in developing dual $\mathrm{M}_{1} / \mathrm{M}_{4}$ agonists (akin to Xanomeline) via the identification of scaffolds through HTS that were then coupled with known pharmacophores of $\mathrm{M}_{4}$ PAMs and hybridized to discover lead compounds. Through their rather extensive SAR efforts, novel, highly selective $\mathrm{M}_{1} / \mathrm{M}_{4}$ agonists based on N-substituted oxindole (blue, 7 , Figure 5) [178], dihydroquinazolinone (green, 8, Figure 5) [179], and 7-azaindoline (red, 9, Figure 5) [180] were developed and evaluated in vitro. Compound 7 partially activated $\mathrm{M}_{1}$ $\left(\mathrm{EC}_{50}=12 \mathrm{nM}\right)$ and $\mathrm{M}_{4}\left(\mathrm{EC}_{50}=29 \mathrm{nM}\right)$ while showing negligible off-target binding and potent CNS penetration. Dihydroquinazolinone (8) was shown to be a high-efficacy $\mathrm{M}_{1}$ $(81 \%)$ agonist but a partial agonist at $\mathrm{M}_{4}(49 \%, 0.3 \mu \mathrm{M})$ with good brain penetration and reversed methamphetamine $\mathrm{AHL}$ in rats $\left(\mathrm{ED}_{50}=3.0 \mathrm{mg} / \mathrm{kg}, \mathrm{sc}\right)$. Further SAR exploration led to the introduction of the methanesulfonyl group into the azaindoline scaffold, which decreased $\mathrm{M}_{1}$ agonistic activity with no loss of activity at $\mathrm{M}_{4}$. A simple addition of a methyl group on the N-carbethoxypiperidine led to compound 9, which displayed high bioavailability $(49 \%, 1 \mathrm{mg} / \mathrm{kg}$, p.o.) in rats, good brain penetration (brain/plasma ratio: $0.9)$, and an $\mathrm{EC}_{50}$ of $13 \mathrm{nM}\left(\mathrm{M}_{4} \mathrm{IA}=81 \%\right.$ at $\left.3 \mu \mathrm{M}\right)$ [180]. No further data have been reported on this or on related compounds; however, these studies provided some insights into key structural elements that can confer $\mathrm{M}_{4}$ subtype specificity (e.g., a basic piperidine core with a terminal ethyl carbamate functional group [purple, Figure 5]).
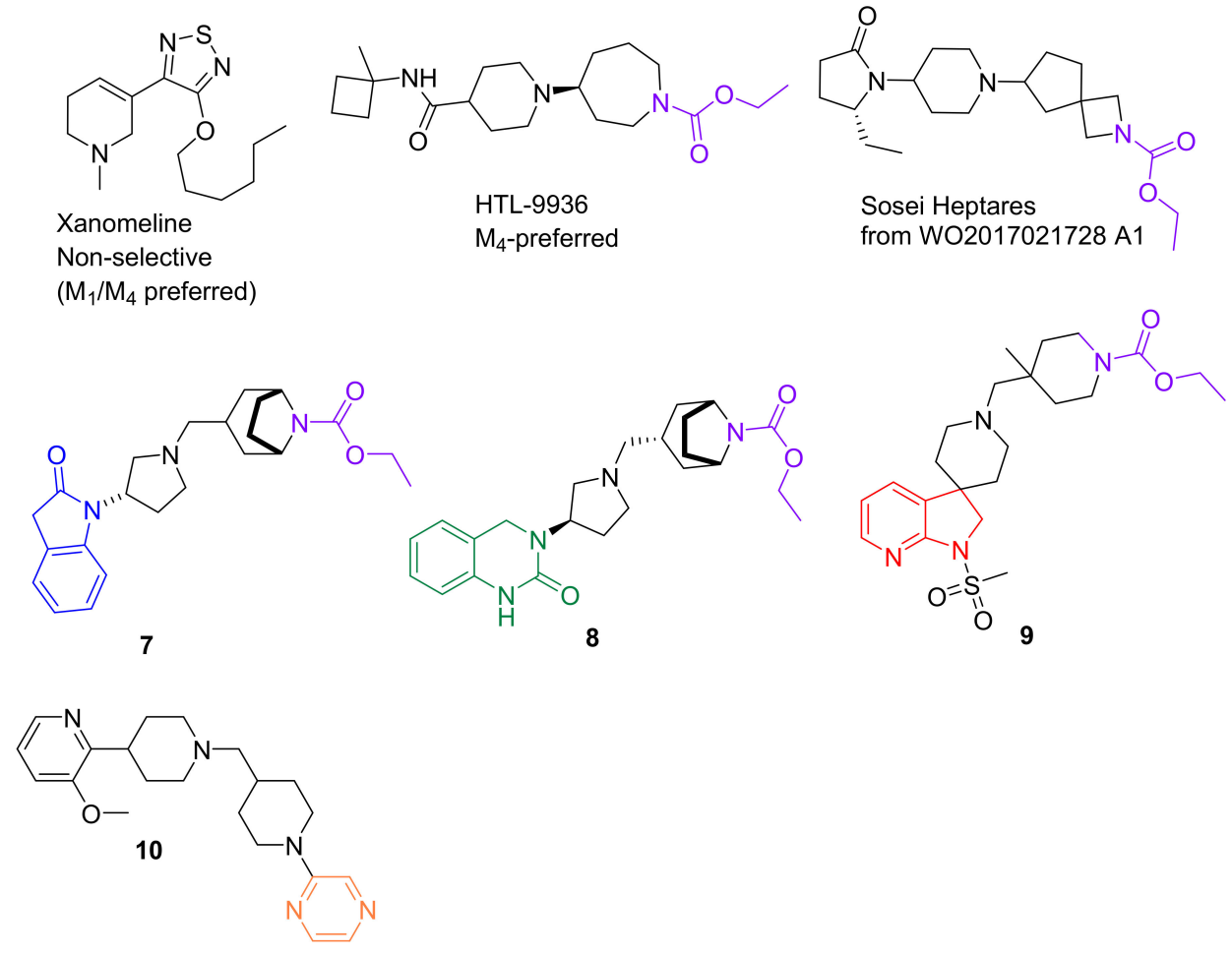

Figure 5. Recent examples of highly selective dual M1/M4 (or M4) agonists. 
Heptares Therapeutics (in partnership with Allergan) presented HTL0016878 (structure not known), a first-in-class highly selective $\mathrm{M}_{4}$ agonist that entered clinical trials in 2017 (NCT03244228; NCT04849286) for the treatment of neurobehavioral symptoms of AD. Nothing further is known about the compound or its progression to further clinical trials. Yet, it remains interesting as the only orthosteric $\mathrm{M}_{4} \mathrm{mAChR}$ drug candidate to advance out of preclinical development.

Pfizer scientists, using carbamate isosteres (e.g., amide, urea, sulfonamide), also have recently sought to develop novel $\mathrm{M}_{4}$-selective orthosteric agonists. These efforts quickly encountered the challenge of retaining $\mathrm{M}_{4}$ activity, leading to a shift in focus to exploring heteroaromatics. Pyrazine (orange, Figure 5) and 1,2,3-thiadiazoles (similar to Xanomeline) were identified as effective ethyl carbamate replacements, resulting in lead compound $\mathbf{1 0}$ that demonstrated $\sim 29$-fold selectivity for $\mathrm{M}_{4}$ [EC50 = $\left.0.296 \mu \mathrm{M}\right]$ over $\mathrm{M}_{2}$ [ > $\left.8.83 \mu \mathrm{M}\right]$ [181]. Due to a high conservation in the orthosteric site, recent efforts in the Pfizer program have shifted focus again, although to designing functionally selective allosteric modulators targeting the $\mathrm{M}_{1}$ and $\mathrm{M}_{4}$ receptors this time (see below). It is noteworthy that, despite some impressive preclinical data from a number of $\mathrm{M}_{1} / \mathrm{M}_{4}$ discovery programs, there has been little success in getting these lead compounds into clinical trials, except for Xanomeline (KarXT) and HTL-9936.

\section{2. $\mathrm{M}_{4}$-Positive Allosteric Modulators}

Drug development efforts for the $\mathrm{M}_{4} \mathrm{mAChR}$ have not been as plentiful as those for $\mathrm{M}_{1}$, which is likely in part due to the high orthosteric homology between $\mathrm{M}_{2} / \mathrm{M}_{4}$ [10]. Lazareno et al. [76] reported that thiochrome (the oxidation product of thiamine, Figure 6) was found to increase the affinity of ACh 3-5 fold for inhibiting $\left[{ }^{3} \mathrm{H}\right] \mathrm{NMS}$ binding to $\mathrm{M}_{4}$ receptors but did not affect $A C h$ affinity at $\mathrm{M}_{1} / \mathrm{M}_{3} / \mathrm{M}_{5}$. Additionally, it decreased the direct binding of $\left[{ }^{3} \mathrm{H}\right] \mathrm{ACh}$ at $\mathrm{M}_{2}$ receptors $(0.1 \mathrm{mM})$, making it the first $\mathrm{M}_{4}$ PAM to be identified. Shortly after, Lilly's campaign (launched in 1997) to identify an $\mathrm{M}_{4}$ PAM produced lead compound LY2033298, followed by Vanderbilt's VU0010010 as first-generation $\mathrm{M}_{4}$ allosteric modulators based on the thieno[2,3-b]-pyridine core in 2008 (blue, Figure 6).

Achieving selectivity at the orthosteric site proved to be a daunting task, as evidenced by unwanted cholinergic AEs in early clinical trials with Xanomeline, hence Lilly's efforts focused on developing M $_{4}$ PAMs. Lead compound LY2033298 displayed robust cooperativity to $\mathrm{ACh}$ and had suitable physicochemical properties for in vivo dosing [181]. It potentiated the behavioral effects of the nonselective $\mathrm{mAChR}$ agonist oxotremorine $(\mathrm{OXO}$ $\mathrm{M})$ in reversing apomorphine-induced disruption of pre-pulse inhibition and conditioned avoidance responding $[182,183]$. Nevertheless, it lacked utility for studies in rodents due to its low potency at rat $\mathrm{M}_{4}\left(\left[\mathrm{rM}_{4}\right]\right.$, 5-6-fold reduction from human $\left.\mathrm{M}_{4}\left[\mathrm{hM}_{4}\right] \mathrm{mAChRs}\right)$ and displayed higher cooperativity for OXO $\mathrm{m}$ than the endogenous ligand, ACh [182]. The introduction of an N-methyl acetylpiperazine functional group generated a close relative to LY2033298, LY2119620, which proved to be unsuitable as a therapeutic due to lack of specificity ( $\mathrm{M}_{2}$ cross-reactivity) [184].

Furthermore, VU0010010 was developed from a chemoinformatics and medicinal chemistry approach to identify a series of highly selective allosteric potentiators of rat $\mathrm{M}_{4}$. The compound demonstrated robust and potent $\left(\mathrm{EC}_{50}=400 \mathrm{nM}\right)$ activity at $\mathrm{M}_{4}$ and potentiated ACh's response 47-fold while showing no activity at other mAChR receptors [185]. Despite showing structural similarity to LY2033298, it lacked the physicochemical properties ( $\log \mathrm{P} \sim 4.5$ ) necessary for in vivo dosing (i.p. doses were not centrally active). Nevertheless, the compound served as a valuable in vitro tool and was further optimized to produce VU0152099 and VU0152100 (Figure 6) [186]. Both compounds demonstrated high $\mathrm{M}_{4}$-subtype specificity with comparable $\mathrm{EC}_{50}$ values to VU0010010 ( 400 nM) and were CNS penetrant after systemic administration. Importantly, both VU0152099 and VU0152100 demonstrated efficacy in reversing AHL in rats/WT mice (not $\mathrm{M}_{4} \mathrm{KO}$ mice) $[187,188]$ when administered alone, implying that there is a sufficient amount of endogenous ACh to mediate these behaviors for modulation with $\mathrm{M}_{4}$ PAMs. This result further supports the 
hypothesis that endogenous ACh plays a vital role in regulating dopaminergic control of motor function.

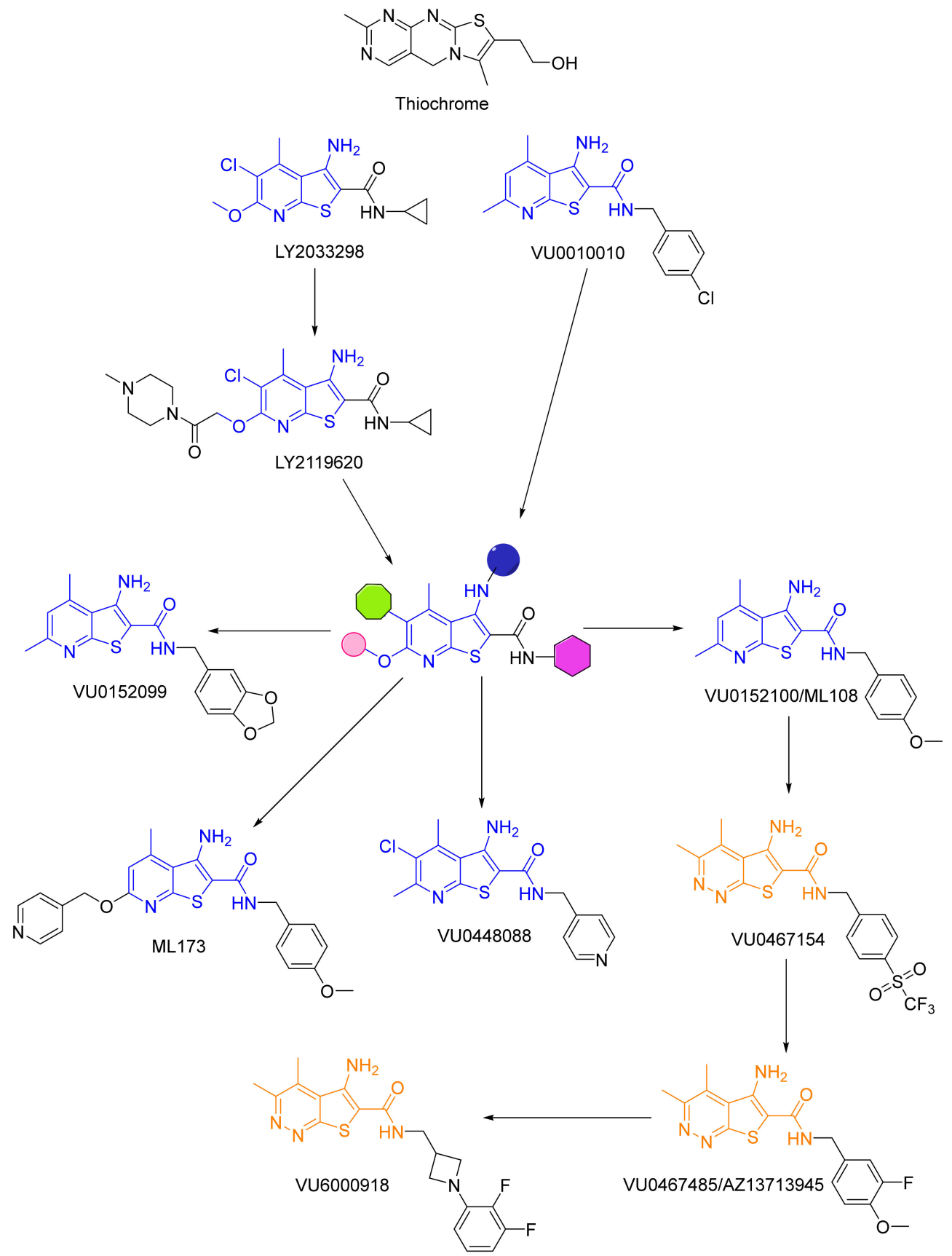

Figure 6. Optimization campaign to arrive at examples of highly selective dual $\mathrm{M}_{1} / \mathrm{M}_{4}$ (or $\mathrm{M} 4$ ) agonists.

These early scaffolds paved the way to newer generations, with the efforts of Vanderbilt at the forefront. Optimization of VU0152100 led to ML173 (Figure 6), which showed more than an order of magnitude greater potency for human $\left(\mathrm{EC}_{50}=95 \mathrm{nM}\right)$ versus rat $(2.4 \mu \mathrm{m}) \mathrm{M}_{4}$ mAChRs [189,190], and VU0448088 [ML253] $\left(\mathrm{hM}_{4} \mathrm{EC}_{50}=56 \mathrm{nM}, \mathrm{rM}_{4} \mathrm{EC}_{50}=176 \mathrm{nM}\right)$ [191]. Wood et al. [192] detailed the SAR of a 5-amino-thieno[2,3-c]pyridazine (orange, Figure 6) series that expanded on the 3-amino-thieno[2,3-b]-pyridine core to produce VU0467154, which displayed a favorable DMPK profile but showed preferential potency $(\sim 35 \times)$ for $\mathrm{rM}_{4}$ versus $\mathrm{hM}_{4}$, preventing clinical use.

Multiple optimization efforts on the benzene ring, which was deemed a metabolic hot spot due to CYP-mediated oxidative demethylation, afforded VU0467485/AZ13713945 
(in collaboration with AstraZeneca). This was one of the first compounds that showed comparable activity at both $\mathrm{hM}_{4}\left(\mathrm{EC}_{50}=78.8 \mathrm{nM}\right)$ and $\mathrm{rM}_{4}\left(\mathrm{EC}_{50}=26.6 \mathrm{nM}\right)$ and displayed no significant species differences in potency (e.g., dog, monkey). Additionally, it showed robust in vivo efficacy preclinical models of SZ and a favorable DMPK profile in rats [193]. Due to high projected therapeutic doses (>450 mg, TID), low CNS penetration, and solubility issues, the compound failed to advance further. Other core scaffolds such as a benzothiazole (e.g., VU0409524, not shown) [194], thieno[2,3-d]pyrimidine (VU6002703, not shown) [195], 6-fluoroquinzoline (VU6003130, not shown) [195], and tricyclic triazoloand imidazopyridine lactams (VU6005877, not shown) [196] have been reported; however, none have reached clinical evaluation to date.

Most recently, Schubert et al. (Merck) [197] conducted an $\mathrm{M}_{4}$ PAM fluorescent imaging plate reader high-throughput screen (FLIPR HTS) of an extensive library of compounds to identify 2,3-substituted pyridine 11 (Figure 7). This was one of the few hits that displayed similar rat and human $\mathrm{M}_{4}$ PAM activity and had excellent subtype selectivity $\left(\mathrm{M}_{1-3}>30 \mu \mathrm{M}\right)$. Its limiting factor was the rate of efflux by P-gp but it served as a model scaffold which the group sought to optimize. After extensive optimization of the aromatic group (red circle), substitution on the core pyridine ring (green circle), and hydrocarbon tail group (blue circle), the group arrived at 12 . This lead compound displayed a relatively similar activity in humans $\left(\mathrm{IC}_{50}=17 \mathrm{nM}\right)$ and rats $\left(\mathrm{IC}_{50}=29 \mathrm{nM}\right)$ and was over $100 \times$ selective for $\mathrm{M}_{4}$ compared to all other subtypes. Additionally, it showed high brain permeability and was shown to reduce AHL in rats with relatively mild cholinergic side-effects (even at much higher doses needed for reduction of AHL). Compound 12 was instrumental in developing a highly selective $\mathrm{M}_{4}$ PET-ligand ([$\left.\left.{ }^{11} \mathrm{C}\right] \mathrm{MK}-6884\right]$ for mapping $\mathrm{M}_{4}$ receptors [198] in AD and ultimately led to MK-4710, which was first disclosed in the Fall 2020 ACS meeting [199]. However, the SAR needed to arrive at this lead structure and plans for clinical development have not yet been revealed.

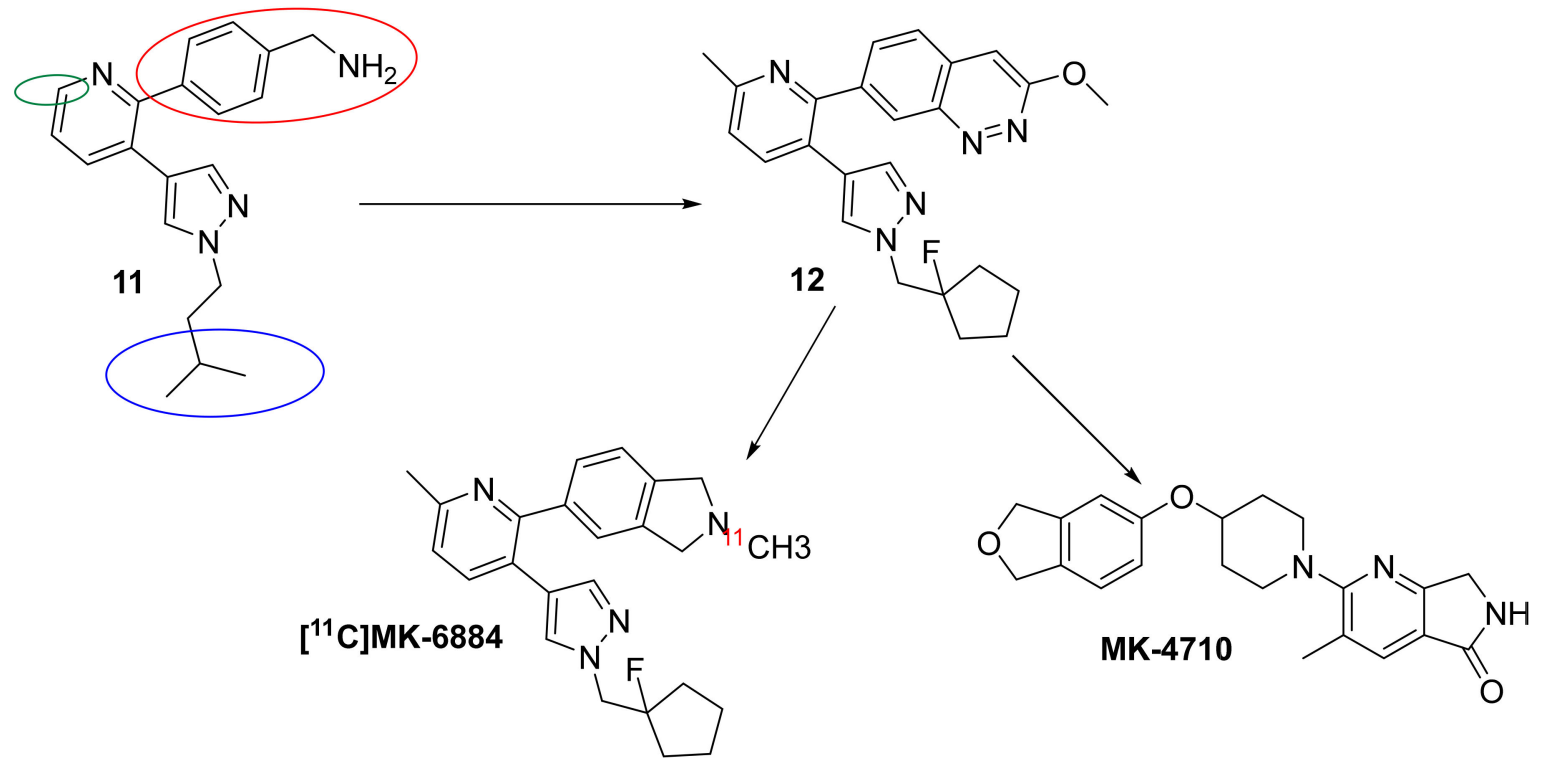

Figure 7. Optimized $\mathrm{M}_{4}$ selective PAMs recently disclosed by Merck.

Despite several setbacks, there is currently a novel $\mathrm{M}_{4}$ PAM, CVL-231 (structure unknown), in clinical development from Cerevel Therapeutics (in partnership with Pfizer). It is now in Phase $1 \mathrm{~b}$ clinical trials that will evaluate the safety, tolerability, and PK/PD of multiple ascending doses of the drug (NCT04136873). The collective data from these above-listed compounds suggest that $\mathrm{M}_{1}$ and $\mathrm{M}_{4}$ subtype-selective PAMs could be valuable tools for elucidating these receptors' exact role in SZ and may represent a novel therapeutic approach for managing symptoms. However, additional studies are needed to 
characterize the pharmacological properties that translate to clinical efficacy versus adverse cholinergic effects.

It is important to note that although none of the described $\mathrm{M}_{1}$ PAMs (in previous sections) have undergone clinical trials for SZ, evidence supports their therapeutic applications in managing the negative symptoms of the disease. Previous work has determined that the $\mathrm{M}_{1} \mathrm{mAChR}$ is coupled to the $\mathrm{N}$-methyl- $d$-aspartate subtype of the glutamate receptor (NMDAR), and $\mathrm{M}_{1}$ activation potentiates NMDAR signaling in both the cortex and hippocampus, both of which are associated with learning and memory [200-202]. Additionally, as noted above, $\mathrm{M}_{1} \mathrm{KO}$ mice also show hyperactivity relative to wild-type controls, suggesting that both receptors likely play a role in controlling locomotor activity [7,152-154].

Furthermore, VU0453595 (Figure 4) was found to be able to rescue cognitive disruptions, long-term depression (LTD), and restore social interactions in mice treated repeatedly with PCP (a mouse model of SZ) [203]. Studies with VU6005246 (difluoro-1H-indole core, green, Figure 5) showed that it dose-dependently reduced cognitive disruptions and hyperlocomotion in GluN1 knockdown mice (a genetic mouse model of NMDA hypofunction), and reversed performance impairments in both the NORT and fear conditioning tasks [204]. These results indicate that these cognitive effects are at least in part mediated by $\mathrm{M}_{1}$.

Spalding et al. [87] and Sur et al. [205] demonstrated N-desmethylclozapine (Figure 4, $\mathrm{N}$-demethylation shown in red), a metabolite of the antipsychotic clozapine, was also a functionally selective $\mathrm{M}_{1}$ agonist that potentially acted through an allosteric mechanism. It was shown to dose-dependently potentiate NMDA receptor currents in CA1 pyramidal cells (widely accepted to be mediated by activation of the mAChRs), perhaps contributing to its clinical utility for schizophrenic patients. Multiple other $\mathrm{M}_{1}$ PAMs such as BQCA [93], PQCA [206,207], PF-06764427 [208], and PF-06767832 [209], among others, have all contributed to the proposal that activation of $\mathrm{M}_{1}$ receptors could have an essential role in medial prefrontal cortex (mPFC)-dependent cognitive functions and modulation of the mesocortical dopamine system [210]. However, more work is needed to determine the effects of the $\mathrm{M}_{1} \mathrm{mAChR}$ on dopamine release.

\section{Drug Design Targeting the mAChRs: Major Depressive Disorder}

Janowsky and colleagues initially proposed the cholinergic hypothesis of depression in the early 1970s, postulating that hyperactivity of the central cholinergic system plays a key role in the pathophysiology of depression [211]. In short, the hypothesis states that mania is likely due to an imbalance of adrenergic activity, while depression is the result of high cholinergic activity [212]. Early evidence was found by demonstrating that direct-acting mAChR agonists (e.g., arecoline) and indirect-acting cholinergic agonists (e.g., AChEI's such as physostigmine) could produce rapid and profound effects on mood in patients with mood disorders. The enhancement of cholinergic activity with physostigmine (via blocking the degradation of Ach) induced symptoms of depression in healthy human subjects and produced a shift in mood state from euphoria to depression in manic patients with BPD [213-216]. Further support for these early findings came when the administration of arecoline and oxetremorine (direct-acting agonists) was shown to worsen the mood state in MDD [217,218] while scopolamine (a nonselective mAChR antagonist) blocked these effects [219].

The mAChRs were explicitly implicated in these effects by evidence showing that polysomnographic responses to selective $\mathrm{mAChR}$ agonists were much greater in depressed patients than in control samples, suggesting that muscarinic receptor hypersensitivity existed in depressed individuals. The cholinergic system in the brain stem plays a significant role in activating the rapid eye movement (REM) and the non-REM sleep cycle. When cholinergic agonists such as RS86, arecoline, and physostigmine were given to patients with MDD, the sensitivity of the REM sleep response increased [220]. In contrast, scopolamine, a $\mathrm{mAChR}$ antagonist, decreased REM sleep and increased sleep latency in patients with depression [221,222]. Additionally, it was shown by various groups [223-225] that variations in CHRM2 (gene encoding for the $\mathrm{M}_{2} \mathrm{mAChR}$ ) were associated with a higher frequency 
and severity of unipolar depression and with abnormal reductions in $\mathrm{M}_{2}$ receptor binding in bipolar depression.

Sex-related effects were also present in mood disorders related to abnormal cholinergic receptor function. In premenopausal females with MDD, there was a higher frequency of heightened cholinergic sensitivity [226,227]. Comings et al. [224] found that genetic variants in the CHRM2 gene (A/T 1890 polymorphism in 3' UTR of CHRM2 gene, homozygotes) were directly associated with MDD in female subjects. Other studies by Luo et al. [228] on the CHRM2 gene revealed modest associations between variation in gene sequence and populations of European-Americans/African Americans with affective disorders. Furthermore, a combination of SNPs, commonly seen $(\sim 40 \%)$ in patients with alcohol dependence and MDD, at the $5^{\prime}$ end of the CHMR2 gene was found to be associated with these two diseases based on the collaborative study on the genetics of alcoholism [228] although other clinical studies have produced conflicting results $[229,230]$. While there are still many unanswered questions regarding the genetic associations underlying depression, a few general hypotheses have been suggested: (1) $\mathrm{M}_{1}$ receptors provide a reliable target to improve cognitive deficits (as described by Merck and others) [231], (2) the $\mathrm{M}_{2} \mathrm{mAChR}$ has been associated with MDD based on single nucleotide polymorphism (SNP) studies (above) and $\mathrm{KO}$ mice, and (3) Gibbons et al. [232] reported a decreased binding of $\mathrm{M}_{2} / \mathrm{M}_{4}$ $\mathrm{mAChRs}$ in the dorsolateral prefrontal cortex of depressed subjects.

The cholinergic hypothesis was further supported by animal studies investigating the psychopharmacological effects of antidepressants on the CNS. Flinders Sensitive Line rats (FSL), bred selectively for increased sensitivity of $\mathrm{mAChRs,} \mathrm{are} \mathrm{considered} \mathrm{to} \mathrm{model}$ certain aspects of depression, including loss of appetite, increases in REM sleep (lethargy), reductions in self-stimulation, learning difficulties, and decreased mobility in the forced swim test (FST) in response to agents that stimulate cholinergic function. However, it does not mimic all the biochemical aspects of depression $[233,234]$. Although we will focus on drugs developed for the $\mathrm{mAChRs}$ in this discussion, the nAChRs deserve mention since they also play a vital role in cholinergic signaling (see Dulawa and Janowsky [235]).

There are several classes of drugs, such as monoamine oxidase inhibitors (MAOIs), tricyclic antidepressants (TCAs), selective serotonin reuptake inhibitors, and serotonin and noradrenaline reuptake inhibitors (SNRIs) that exist today for the treatment of depression. The drugs were designed based on the monoamine theory of depression that predicts the underlying pathophysiologic basis of depression, i.e., a depletion in serotonin, norepinephrine, and/or dopamine levels in the CNS [236,237]. Although differing in their selectivity for specific receptors or transporters, their primary function is to enhance either serotonergic or noradrenergic neurotransmission. It was concluded early on by El-Fakahany [238] (and more recently by Siafis and Papazisis [239]) that most, if not all, were antagonists of the $\mathrm{mAChRs}$ with the tricyclic antidepressants (e.g., amitriptyline, butriptyline, trimipramine, etc.) showing higher efficacy in MDD patients [240-242]. Janowsky et al. [211] and Davis et al. [243] postulated that the antimuscarinic properties (e.g., a mAChR blockade) were responsible for the mood-elevating effects (reviewed in Dagyte et al. [213]). However, these drugs have been shown to have many other actions associated with their affinity for histamine, dopamine, serotonin, adrenergic, and the mAChRs [237].

Little has been produced that is more effective than the original TCAs or MAOIs despite over 50 years of research in the field. While antidepressant drugs have been beneficial to many, according to the NIMH-funded STAR ${ }^{*} \mathrm{D}$ (Sequenced Treatment Alternatives to Relieve Depression) clinical trials, $47 \%$ of patients' symptoms are not adequately treated within the first antidepressant regimen (usually an SSRI), and 30\% after four different treatments [244-246]. Additionally, currently approved drugs must typically be administered 4-6 weeks before a therapeutic effect is achieved. This delayed action is not well understood and presents a significant challenge for medical professionals in managing MDD. This delay prolongs patient suffering, delays the implementation of potential new treatments, and increases the risk of disease-related health issues (including death by suicide). 
Furthermore, many available antidepressant medications have adverse side effects, such as anxiety, agitation, suicidal ideations, and declines in short-term memory and cognitive function $[247,248]$. Chronic use is accompanied by a cognitive disruption in $30 \%$ of subjects [249], uncomfortable symptoms following discontinuation [250,251], and the drugs have been recently found to increase the likelihood of developing dementia in old age [252-254]. Not surprisingly, the urgent need for novel antidepressants with an improved side-effect profile has been noted by multiple investigators [255,256]. Later generations of antidepressants (e.g., bupropion, citalopram, duloxetine, fluoxetine, sertraline, etc.) have improved selectivity for their respective transporters (hence more favorable side effect profile), yet still have considerable limitations in treating the condition [241,257].

To properly treat patients suffering from mood disorders, the urgent need persists for rapid antidepressant therapies that avoid the delayed onset of classical antidepressants. This is important not only for those suffering from MDD but also for a small subset of patients whose treatment response is minimal or absent altogether [258-260]. Treatment-resistant depression (TRD) severely limits treatment options for clinicians, despite accounting for about $30 \%$ of all patients suffering from depression. Some reassurance came from replicating earlier findings by Berman et al. [260], confirming NMDA receptor channel blocker ketamine produced rapid improvement in mood in TRD patients [261]. The results were confirmed again in a small clinical trial by Zarate et al. [262] and confirm the NMDA blockade hypothesis initially proposed by Trullas and Skolnick [263] about three decades ago. In March 2019, intranasal (S)-ketamine (esketamine or Spravato) received FDA approval to be administered as a supplemental treatment for adults with TRD. The approval was based upon the efficacy of esketamine in short-term clinical trials [264] and longer-term maintenance investigations (focusing on individualization of treatment) [265](NCT02497287/NCT02782104). It is worthy of mention that ketamine has been shown to cause dizziness, vertigo, headache, increases in blood pressure, and to produce dissociative effects [266,267]. In addition to these safety concerns, ongoing studies are underway to assess the durability of the antidepressant effects of ketamine, with maintenance dosing being at the forefront [268,269].

Mechanisms of antidepressants have been a significant focus of current and past research to develop more effective and faster-acting drugs. In studies to assess whether a reduction in $\mathrm{mAChR}$ function would alleviate depressive symptoms, clinical data showed that the nonselective mAChR antagonist scopolamine (Figure 8) had antidepressant effects in patients with either MDD or BPD [270]. No participants in the trial dropped out due to adverse side effects, likely attributed to the low dose $(4 \mu \mathrm{g} / \mathrm{kg})$. However, scopolamine and other known anticholinergic drugs have side effects, especially with long-term use. These include double vision, increased heart rate, confusion, disorientation, euphoria/dysphoria, memory problems, mental confusion, or other CNS effects that resemble delirium [271-273]. One of the downsides of utilizing scopolamine as an antidepressant is cognitive impairment, especially at higher doses (e.g., $\geq 8 \mu \mathrm{g} / \mathrm{kg}$ ). Since MDD is already associated with cognitive deficits [274,275], this would produce an undesired additive effect that would only exacerbate the problem. In summary, the cholinergic hypothesis of depression can be based on the following findings: (1) current antidepressants are high-affinity antagonists at the mAChRs; (2) cholinergic stimulation leads to symptoms of depression; (3) scopolamine produces relatively rapid and robust antidepressant effects even in those patients that were refractory to previous treatments; (4) the mechanism of scopolamine in part resembles that of ketamine (discussed below).<smiles>CN1C2CC(OC(=O)C(CO)c3ccccc3)CC1C1OC12</smiles>

(-)-Scopolamine hydrobromide

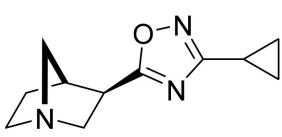

L687306

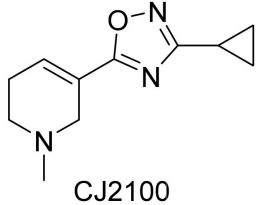

CJ2100

Figure 8. Examples of potential antidepressants targeting the mAChRs. 
Scopolamine's antidepressant effects mechanism is still not well understood, particularly its persistence of antidepressant action, due to its relatively short clearance time from plasma $\left(\mathrm{t}_{1 / 2}=2-4 \mathrm{~h}\right)$-although it has been shown to have a long residence time in tissues. This result suggests a mechanism other than the direct blockade of the mAChR receptors. The persistent antidepressant response that lasted long after the anticholinergic side effects (reported to have dissipated within $5 \mathrm{~h}$ in the clinical study) lends to the hypothesis that the drug may alter synaptic plasticity or gene expression through a variety of direct/indirect mechanisms [276].

To better understand the mechanism of scopolamine, Voleti et al. [277] examined the role between the mammalian target of rapamycin complex 1 (mTORC1) and synaptogenesis in the PFC, which has also been implicated in the rapid actions of NMDA antagonists. They discovered that a single, low dose $(25 \mu \mathrm{g} / \mathrm{kg})$ significantly induced phosphor-mTOR, phosphor-Akt, and phosphor-S6K $1 \mathrm{hr}$ post-treatment (Western blot). Similarly, telenzepine ( $3 \mathrm{mg} / \mathrm{kg}$, known to have limited selectivity for the $\mathrm{M}_{1} \mathrm{mAChR}$ ) showed increased expression of the same proteins. In congruence from earlier studies of ketamine [278], scopolamine administration rapidly increased the number of spines within the distal segments of layer $\mathrm{V}$ neurons in the PFC and produced a small but significant increase in spine head diameter are consistent with increased synaptic function [276]. As expected, scopolamine $(25 \mu \mathrm{g} / \mathrm{kg})$ showed antidepressant activity in the FST but was blocked upon pretreatment with the selective mTORC1 inhibitor rapamycin, similar to ketamine. The group also demonstrated that pretreatment with the known $\alpha$-amino-3-hydroxy-5-methyl-4-isoxazolepropionic acid (AMPA) receptor antagonist NBQX blocked the antidepressant actions of scopolamine in the FST, confirming a requirement for glutamate-AMPA activity.

In a follow-up study by Navarria et al. [279], scopolamine microinfusions directly to the infralimbic (IL) and prelimbic (PrL) subregions of the mPFC produced responses in the FST. However, neuronal silencing of these regions blocked the effects. Additionally, systemic administration of VU0255035, a selective $\mathrm{M}_{1}$ antagonist, displayed an antidepressant response and increased $\mathrm{mTORC} 1$ signaling in the PFC. Their results also demonstrated that a single dose of either scopolamine or VU0255035 blocked the anhedonic response caused by chronic unpredictable stress (CUS). These results indicate that the $\mathrm{MPFC}$ is a vital mediator of scopolamine's behavioral actions and points to the $\mathrm{M}_{1}$ receptor as a therapeutic target for developing novel and selective rapid-acting antidepressants. In further support of these above results, Witkin et al. [280] utilized both wild-type and KO mice to identify the subtypes responsible for the antidepressant action of scopolamine. $\mathrm{M}_{1}$ and $\mathrm{M}_{2} \mathrm{KO}$ mice showed a diminished response to scopolamine (but not imipramine) in the FST, indicating that both of these receptors likely play a role in scopolamine's antidepressant effects.

Wohleb et al. [281] also demonstrated the role of $\mathrm{M}_{1} \mathrm{mAChRs}$ in mediating scopolamine's antidepressant effects in rodents by subjecting the animals to chronic mild stress (a preclinical model of depression). By using a viral-mediated knockdown of $\mathrm{M}_{1} \mathrm{mAChRs}$ specifically in GABAergic neurons, but not glutaminergic neurons, in the $\mathrm{mPFC}$, scopolamine's antidepressant effects are significantly diminished. Therefore, it can be concluded that blocking these receptors produces a short-term burst of glutamate that results in neuroplasticity effects at the glutamatergic synapse [281,282].

As noted previously, the selective $\mathrm{M}_{1}$ agonism (through selective orthosteric agonists or PAMs) has long been accepted as a method to enhance cognition, and consequently, $\mathrm{M}_{1}$ antagonism has been viewed as detrimental. However, scopolamine produced cognitive deficits in both wild-type and $\mathrm{M}_{1} \mathrm{KO}$, which could infer that antagonism of $\mathrm{M}_{1}$ may not be a cause for concern [271]. This, however, has yet to be tested experimentally. While the $\mathrm{M}_{2}$ receptor has been implicated in the pathophysiology of mood disorders and depression (detailed previously), its utility as a target could be compromised by its high prevalence in cardiac tissue [283].

There is less convincing evidence to support the targeting of $\mathrm{M}_{3}, \mathrm{M}_{4}$, and $\mathrm{M}_{5}$ receptors. $\mathrm{M}_{3}$ is enriched in the GI tract and bladder tissues but shows low levels of expression in the hippocampus and cortex $[38,284,285]$. $\mathbf{M}_{4}$ has a similar expression level to $\mathrm{M}_{1}$ in 
specific brain regions (hippocampus, cerebral cortex, striatum). In the striatum where $\mathrm{M}_{4}$ is most highly expressed with $\mathrm{M}_{1}$, dense patches of receptor expression correspond to postsynaptic sites on medium spiny neurons, which modulates GABA release. More significantly, $\mathrm{M}_{4}$ (like $\mathrm{M}_{2}$ ) is known to be an autoreceptor that inhibits the release of $\mathrm{ACh}$; therefore, antagonizing this receptor (as with $\mathrm{M}_{2}$ ) would serve to enhance cholinergic signaling $[162-165,286]$ and likely would not produce an effective antidepressant. Finally, $\mathrm{M}_{5}$ is expressed exclusively (and only in particular regions) in the CNS, albeit at low levels. These regions include the VTA projections to the nAcc, which modulates dopamine release, the hippocampus, substantia nigra, and peripheral and cerebral blood vessels [287-289]. As VTA dopamine release has been related to the mediation of stress responses, it could potentially mitigate depressive symptoms (via mediation of anhedonia-like behaviors) [271,290].

Aside from studies on scopolamine, there has been little published on muscarinic antagonists as potential antidepressants. In the past year, Johnson et al. [291] reported the development of two potential lead compounds (L-687306 and CJ2100, Figure 8) targeting the orthosteric site acting as rapid-acting antidepressants that lack cognitive deficits. Additionally, L-687306 was synthesized and evaluated as a possible treatment of AD in the early 1990s by Merck [292-294] to identify a more selective mAChR agonist with reduced efficacy (hence reduced cholinergic side-effect profile), and CJ2100 is a cyclopropyl oxadiazole derivative of arecoline. These compounds were compared with scopolamine in vitro and across several in vivo assays that reflected autonomic and central activity. As shown in Figure 9, each of these compounds displayed similar effects in the FST, decreasing immobility and increasing either swimming or climbing (suggesting antimuscarinicmediated antidepressant activity). Additionally, scopolamine and CJ2100 reduced immobility in the FST without significantly altering locomotor activity at the same doses, leading the authors to conclude that the effects in the FST were independent of general activity stimulating properties.

As a proof of principle to show the possibility of designing a muscarinic antagonist without cognitive deficits, the group also evaluated each compound in cognitive assays of attention (Psychomotor Vigilance Task) and memory (Titrating Delay Matching to Position Task). Both L-687,306 and CJ2100 showed no detrimental effects in either assay (up to $10 \mathrm{mg} / \mathrm{kg}$ ) as opposed to scopolamine, which produced dose-dependent impairments in both tasks. Based on their results, it is possible to design functionally selective drugs that target the orthosteric site of the mAChRs. Additionally, it proves the utility of drug design methods targeting these receptors as a novel way to treat depression.

In summary, scopolamine has produced robust antidepressant effects in animal models of depression and has demonstrated efficacy in multiple clinical trials. The current findings thus far most clearly support that the antagonism of $\mathrm{M}_{1}$ should potentially provide a novel way to treat depression. However, emerging data also implicates the $\mathrm{M}_{5}$ receptor in modulating dopamine release in the midbrain, and as such, it would be appropriate to study whether antagonism at $\mathrm{M}_{5}$ could potentially mitigate anhedonic-like phenotypes in stress models (i.e., Nunes et al.) [295]. 


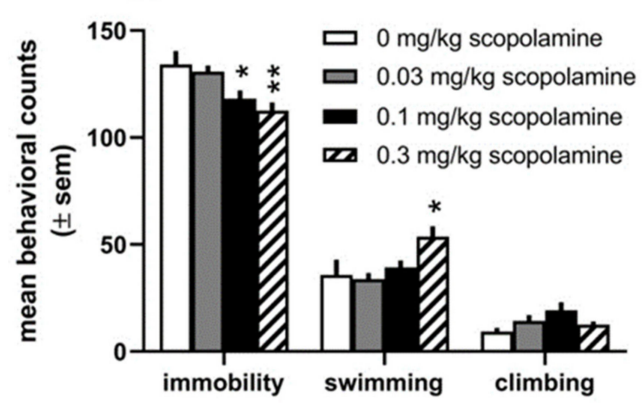

C

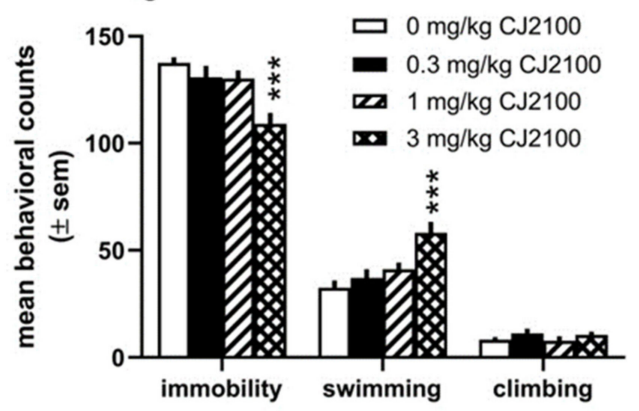

B

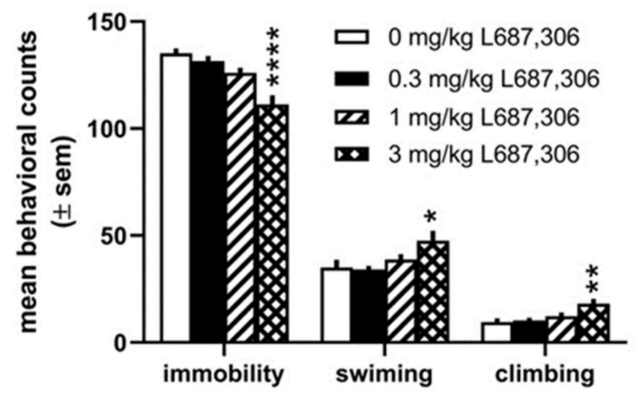

D

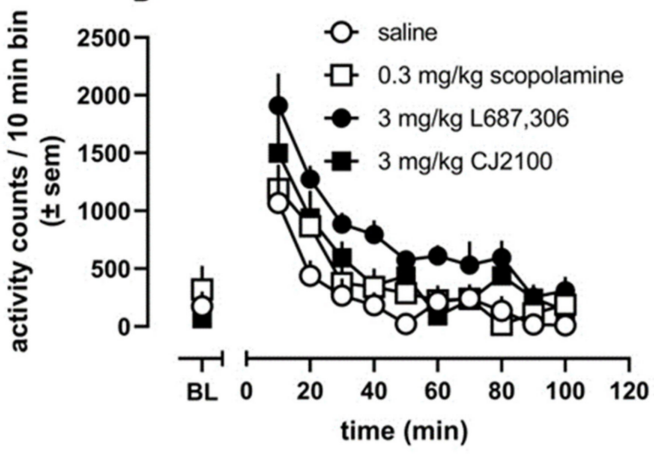

E

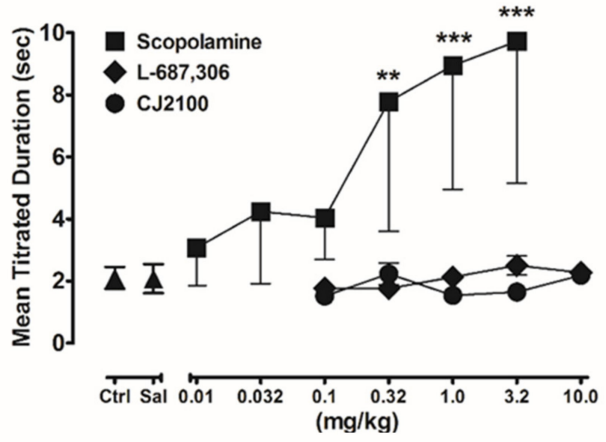

F

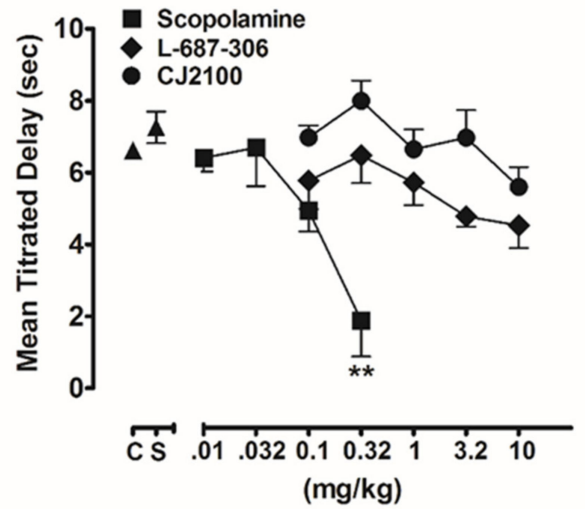

Figure 9. Effects of several doses of Scopolamine (A), L-687,306 (B), and CJ2100 (C) on counts of immobility, swimming, and climbing in the forced swim test. (D) Locomotor activity at doses that produced decreases in immobility in the FST. (E) Dose-related effects of scopolamine (squares), L687,306 (diamonds), and CJ2100 (circles) on mean titrated duration (seconds) in the psychomotor vigilance task. (F) Dose-related effects of the compounds on the mean titrated delay (seconds) in the titrating delay matching-to-position task. ${ }^{*} p<0.05,{ }^{* *} p<0.01,{ }^{* * *} p<0.001,{ }^{* * * *} p<0.0001$. Reproduced with permission from Johnson CR et al. [291]. 


\section{Conclusions}

Despite advances in GPCR crystallography in solving the structures of the $\mathrm{M}_{1}-\mathrm{M}_{4}$ receptors, targeting the $\mathrm{mAChRs}$ in drug design remains an elusive task. Binding simulations and the vast array of crystal structures currently available have allowed drug discovery efforts to be expedited from traditional high throughput screening (HTS) to virtual screening or fragment-based drug design. Both latter methods require fewer resources and serve as a template for selecting potential lead molecules to be evaluated via other methods. These efforts have identified multiple orthosteric and highly selective allosteric modulators of the mAChRs to treat CNS indications, some of which have progressed to clinical trials (summarized above).

Much remains to be learned about allosteric modulation of the mAChRs due to the complex interactions between the receptor, orthosteric ligand, and allosteric modulator. Alteration of any of these could lead to different cooperativity and subsequently skew the drug's pharmacological profile interpretation. Additionally, unlike the orthosteric site that can be narrowed to specific key residues responsible for high-affinity binding (or functional selectivity), single residues cannot be identified that determine the type and strength of cooperativity. This is likely due to many domains playing a crucial role in the $\alpha$-values.

While allosteric modulation has primarily been the focus of recent efforts, it should not preclude the design of functionally selective orthosteric ligands, as demonstrated by the development of the highly selective $\mathrm{M}_{1} / \mathrm{M}_{4}$ ligands for AD/SZ and also functionally selective $\mathrm{mAChR}$ antagonists as a novel treatment for depression. A great amount of effort has been dedicated to targeting the mAChRs for treating CNS disorders, and the field continues to remain largely open for discoveries.

Author Contributions: Writing-Original Draft Preparation: C.R.J.; Writing-Reviewing and Editing: C.R.J., B.D.K., E.M.J., J.B., A.C. All authors have read and agreed to the published version of the manuscript.

Funding: Funding for the research was provided by NIMH R01-107499.

Conflicts of Interest: The authors are co-holders of a pending US patent on CJ 2100 (WO2020206410) and declare no other conflicts of interest.

\section{References}

1. Fredriksson, R.; Lagerstrom, M.C.; Lundin, L.G.; Schioth, H.B. The G protein-coupled receptors in the human genome form five main families. Phylogenetic analysis, paralogon groups, and fingerprints. Mol. Pharmacol. 2003, 63, 1256-1272. [CrossRef] [PubMed]

2. Bockaert, J.; Pin, J.P. Molecular tinkering of G protein-coupling receptors: An evolutionary success. EMBO J. 1999, 18, 1723-1729. [CrossRef] [PubMed]

3. Wettschureck, N.; Offermanns, S. Mammalian G Proteins and Their Cell Type Specific Functions. Physiol. Rev. 2005, 85, 1159-1204. [CrossRef] [PubMed]

4. Lagerström, M.C.; Schiöth, H.B. Structural diversity of G protein-coupled receptors and significance for drug discovery. Nat. Rev. Drug Discov. 2008, 7, 339-357. [CrossRef]

5. Conn, P.M.; Ulloa-Aguirre, A.; Ito, J.; Janovick, J.A. G Protein-Coupled Receptor Trafficking in Health and Disease: Lessons Learned to Prepare for Therapeutic Mutant Rescue in Vivo. Pharmacol. Rev. 2007, 59, 225-250. [CrossRef]

6. Fang, Y.; Kenakin, T.; Liu, C. Editorial: Orphan GPCRs As Emerging Drug Targets. Front. Pharmacol. 2015, 6, 295. [CrossRef]

7. Wess, J.; Eglen, R.M.; Gautam, D. Muscarinic acetylcholine receptors: Mutant mice provide new insights for drug development. Nat. Rev. Drug Discov. 2007, 6, 721-733. [CrossRef]

8. Haga, K.; Kruse, A.C.; Asada, H.; Yurugi-Kobayashi, T.; Shiroishi, M.; Zhang, C.; Weis, W.I.; Okada, T.; Kobilka, B.K.; Haga, T.; et al Structure of the human M2 muscarinic acetylcholine receptor bound to an antagonist. Nature 2012, 482, 547-551. [CrossRef]

9. Kruse, A.C.; Hu, J.; Pan, A.C.; Arlow, D.H.; Rosenbaum, D.M.; Rosemond, E.; Green, H.F.; Liu, T.; Chae, P.S.; Dror, R.O.; et al. Structure and dynamics of the M3 muscarinic acetylcholine receptor. Nature 2012, 482, 552-556. [CrossRef]

10. Thal, D.M.; Sun, B.; Feng, D.; Nawaratne, V.; Leach, K.; Felder, C.C.; Bures, M.G.; Evans, D.A.; Weis, W.I.; Bachhawat, P.; et al. Crystal structures of the M1 and M4 muscarinic acetylcholine receptors. Nature 2016, 531, 335-340. [CrossRef]

11. Wess, J. Novel Muscarinic Receptor Mutant Mouse Models. Handb. Exp. Pharmacol. 2011, 95-117. [CrossRef]

12. Contestabile, A. The history of the cholinergic hypothesis. Behav. Brain Res. 2011, 221, 334-340. [CrossRef] [PubMed]

13. Bowen, D.M.; Smith, C.B.; White, P.; Davison, A.N. Neurotransmitter-related enzymes and indices of hypoxia n senile dementia and other abiotrophies. Brain 1976, 99, 459-496. [CrossRef] [PubMed] 
14. Davies, P.; Maloney, A.J.F. Selective loss of central cholinergic neurones in Alzheimer's disease. Lancet 1976, 2, 1403. [CrossRef]

15. Nilsson, L.; Nordberg, A.; Hardy, J.; Wester, P.; Winblad, B. Physostigmine restores3H-acetylcholine efflux from Alzheimer brain slices to normal level. J. Neural Transm. 1986, 67, 275-285. [CrossRef]

16. Rylett, R.; Ball, M.; Colhoun, E. Evidence for high affinity choline transport in synaptosomes prepared from hippocampus and neocortex of patients with Alzheimer's disease. Brain Res. 1983, 289, 169-175. [CrossRef]

17. Bartus, R.T.; Dean III, R.L.; Beer, B.; Lippa, A.S. The cholinergic hypothesis of geriatric memory dysfunction. Science 1982, 217, 408-414. [CrossRef]

18. Whitehouse, P.J.; Price, D.L.; Struble, R.G.; Clark, A.W.; Coyle, J.T.; Delon, M.R. Alzheimer's disease and senile dementia: Loss of neurons in the basal forebrain. Science 1982, 215, 1237-1239. [CrossRef] [PubMed]

19. Fillit, H.; Hill, J.W.; Futterman, R. Health care utilization and costs of Alzheimer's disease: The role of co-morbid conditions, disease stage and pharmacotherapy. Fam. Med. 2002, 34, 528-535.

20. Selkoe, D.J. Alzheimer's disease: Genes, proteins and therapy. Physiol. Rev. 2001, 81, 741-766. [CrossRef]

21. Mouradian, M.M.; Mohr, E.; Williams, J.A.; Chase, T.N. No response to high-dose muscarinic agonist therapy in Alzheimer's disease. Neurology 1988, 38, 606. [CrossRef] [PubMed]

22. Vetrivel, K.S.; Thinakaran, G. Amyloidogenic processing of beta-amyloid precursor protein in intracellular compartments Neurology 2006, 66 (Suppl. 1), S69-S73. [CrossRef] [PubMed]

23. Caine, E.D. Cholinomimetic Treatment Fails to Improve Memory Disorders. New Engl. J. Med. 1980, 303, 585-586. [CrossRef]

24. Barten, D.M.; Albright, C.F. Therapeutic strategies for Alzheimer's disease. Mol. Neurobiol. 2008, 37, 171-186. [CrossRef]

25. Soukup, O.; Winder, M.; Killi, U.K.; Wsól, V.; Jun, D.; Kuca, K.; Tobin, G. Acetylcholinesterase Inhibitors and Drugs Acting on Muscarinic Receptors-Potential Crosstalk of Cholinergic Mechanisms During Pharmacological Treatment. Curr. Neuropharmacol. 2017, 15, 637-653. [CrossRef]

26. Tan, C.C.; Yu, J.T.; Wang, H.F.; Tan, M.S.; Meng, X.F.; Wang, C.; Jiang, T.; Zhu, X.C.; Tan, L. Efficacy and safety of donepezil, galantamine, rivastigmine, and memantine for the treatment of Alzheimer's disease: A systematic review and meta-analysis. $J$. Alzheimer's Dis. 2014, 41, 615-631. [CrossRef]

27. Street, L.J.; Baker, R.; Book, T.; Kneen, C.O.; MacLeod, A.M.; Merchant, K.J.; Showell, G.A.; Saunders, J.; Herbert, R.H.; Freedman, S.B.; et al. Synthesis and biological activity of 1,2,4-oxadiazole derivatives: Highly potent and efficacious agonists for cortical muscarinic receptors. J. Med. Chem. 1990, 33, 2690-2697. [CrossRef]

28. Perry, E.K. The cholinergic hypothesis-ten years on. Br. Med. Bull. 1986, 42, 63-69. [CrossRef]

29. Perry, E. Acetylcholine and Alzheimer's Disease. Br. J. Psychiatry 1988, 152, 737-740. [CrossRef]

30. Sims, N.R.; Bowen, D.M.; Allen, S.J.; Smith, C.C.; Neary, D.; Thomas, D.J.; Davidson, A.N. Presynaptic cholinergic dysfunction in patients with dementia. J. Neurochem. 1983, 40, 503-509. [CrossRef]

31. Wei, J.; Walton, E.A.; Milici, A.; Buccafusco, J.J. m1-m5 Muscarinic Receptor Distribution in Rat CNS by RT-PCR and HPLC. J. Neurochem. 2002, 63, 815-821. [CrossRef] [PubMed]

32. Davoren, J.E.; Garnsey, M.; Pettersen, B.; Brodney, M.A.; Edgerton, J.R.; Fortin, J.P.; Grimwood, S.; Harris, A.R.; Jenkinson, S.; Kenakin, T.; et al. Design and Synthesis of $\gamma$ - and $\delta$-Lactam M1 Positive Allosteric Modulators (PAMs): Convulsion and Cholinergic Toxicity of an M1-Selective PAM with Weak Agonist Activity. J. Med. Chem. 2017, 60, 6649-6663. [CrossRef] [PubMed]

33. Miyauchi, M.; Neugebauer, N.M.; Sato, T.; Ardehali, H.; Meltzer, H.Y. Muscarinic receptor signaling contributes to atypical anti-psychotic drug reversal of the phencyclidine-induced deficit in novel object recognition in rats. J. Psychopharmacol. 2017, 31, 1588-1604. [CrossRef] [PubMed]

34. Gould, R.W.; Dencker, D.; Grannan, M.; Bubser, M.; Zhan, X.; Wess, J.; Xiang, Z.; Locuson, C.; Lindsley, C.W.; Conn, P.J.; et al. Role for the M1 Muscarinic Acetylcholine Receptor in Top-Down Cognitive Processing Using a Touchscreen Visual Discrimination Task in Mice. ACS Chem. Neurosci. 2015, 6, 1683-1695. [CrossRef]

35. Anagnostaras, S.G.; Murphy, G.G.; Hamilton, S.E.; Mitchell, S.L.; Rahnama, N.P.; Nathanson, N.M.; Silva, A.J. Selective cognitive dys-function in acetylcholine M1 muscarinic receptor mutant mice. Nat. Neurosci. 2003, 6, 51-58. [CrossRef]

36. Lebois, E.P.; Thorn, C.; Edgerton, J.R.; Popiolek, M.; Xi, S. Muscarinic receptor subtype distribution in the central nervous system and relevance to aging and Alzheimer's disease. Neuropharmacology 2018, 136, 362-373. [CrossRef]

37. Foster, D.; Conn, P.J. Allosteric Modulation of GPCRs: New Insights and Potential Utility for Treatment of Schizophrenia and Other CNS Disorders. Neuron 2017, 94, 431-446. [CrossRef]

38. Bubser, M.; Byun, N.; Wood, M.R.; Jones, C.K. Muscarinic Receptor Pharmacology and Circuitry for the Modulation of Cognition. Handb. Exp. Pharmacol. 2011, 121-166. [CrossRef]

39. Caccamo, A.; Oddo, S.; Billings, L.M.; Green, K.N.; Martínez-Coria, H.; Fisher, A.; LaFerla, F.M. M1 Receptors Play a Central Role in Modulating AD-like Pathology in Transgenic Mice. Neuron 2006, 49, 671-682. [CrossRef]

40. Jones, C.K.; Brady, A.E.; Davis, A.A.; Xiang, Z.; Bubser, M.; Tantawy, M.N.; Kane, A.S.; Bridges, T.M.; Kennedy, J.P.; Bradley, S.R.; et al. Novel selective allosteric activator of the M1 muscarinic acetylcholine receptor regulates amyloid processing and produces antipsychotic-like activity in rats. J. Neurosci. 2008, 28, 10422-10433. [CrossRef]

41. Sauerberg, P.; Olesen, P.H.; Nielson, S.; Treppendahl, S.; Sheardown, M.J.; Honore, T.; Mitch, C.H.; Ward, J.S.; Pike, A.J. Novel functional M1 selective muscarinic agonists. Synthesis and structure-activity relationships of 3-(1,2,5-thiadiazolyl)-1,2,5,6tetrahydro-1-methylpyridines. J. Med. Chem. 1992, 35, 2274-2283. [CrossRef] 
42. Ward, J.S.; Merritt, L.; Klimkowski, V.J.; Lamb, M.L.; Mitch, C.H.; Bymaster, F.P.; Sawyer, B.; Shannon, H.E.; Olesen, P.H. Novel functional M1 selective muscarinic agonists. Synthesis and structure-activity relationships of 3-pyrazinyl-1,2,5,6-tetrahydro-1methylpyridines. Construction of a molecular model for the M1 pharmacophore. J. Med. Chem. 1992, 35, 4011-4019. [CrossRef]

43. Bodick, N.C.; Offen, W.W.; Levey, A.I.; Cutler, N.R.; Gauthier, S.G.; Satlin, A.; Shannon, H.E.; Tollefson, G.D.; Rasmussen, K.; Bymaster, F.P.; et al. Effects of xanomeline, a selective muscarinic receptor agonist, on cognitive function and behavioral symptoms in Alzheimer's disease. Arch. Neurol. 1997, 54, 465-473. [CrossRef]

44. Shekhar, A.; Potter, W.Z.; Lightfoot, J.; Lienemann, J.; Dube, S.; Mallinckrodt, C.; Bymaster, F.P.; McKinzie, D.L.; Felder, C.C Selective Muscarinic Receptor Agonist Xanomeline as a Novel Treatment Approach for Schizophrenia. Am. J. Psychiatry 2008, 165, 1033-1039. [CrossRef]

45. Melancon, B.J.; Tarr, J.C.; Panarese, J.D.; Wood, M.R.; Lindsley, C.W. Allosteric modulation of the M1 muscarinic acetylcholine re-ceptor: Improving cognition and a potential treatment for schizophrenia and Alzheimer's disease. Drug Discov. Today 2013, 18, 1185-1199. [CrossRef]

46. Noetzel, M.J.; Grant, M.K.O.; El-Fakahany, E.E. Immediate and Delayed Consequences of Xanomeline Wash-Resistant Binding at the M3 Muscarinic Receptor. Neurochem. Res. 2008, 34, 1138-1149. [CrossRef]

47. Messer, W.S. The utility of muscarinic agonists in the treatment of alzheimer's disease. J. Mol. Neurosci. 2002, 19, 187-193. [CrossRef]

48. Mirza, N.R.; Peters, D.; Sparks, R.G. Xanomeline and the Antipsychotic Potential of Muscarinic Receptor Subtype Selective Agonists. CNS Drug Rev. 2006, 9, 159-186. [CrossRef]

49. Ward, J.S.; Merritt, L.; Calligaro, D.O.; Bymaster, F.P.; Shannon, H.E.; Sawyer, B.D.; Mitch, C.H.; Deeter, J.B.; Peters, S.C Functionally selective M1 muscarinic agonists. Side chain and azacycles contributing to functional muscarinic selectivity among pyrazinylazacycles. J. Med. Chem. 1995, 38, 3469-3481. [CrossRef]

50. Moltzen, E.K.; Pedersen, H.; Boegesoe, K.P.; Meier, E.; Frederiksen, K.; Sanchez, C.; Lemboel, H.L. Bioisosteres of Arecoline: 1,2,3,6-Tetrahydro-5-pyridyl-Substituted and 3-Piperidyl-Substituted Derivatives of Tetrazoles and 1,2,3-Triazoles. Synthesis and Muscarinic Activity. J. Med. Chem. 1994, 37, 4085-4099. [CrossRef]

51. Bromidge, S.M.; Brown, F.; Cassidy, F.; Clark, M.S.; Dabbs, S.; Hadley, M.S.; Loudon, J.M.; Orlek, B.S.; Riley, G.J. Design and synthesis of azabicyclic muscarinic agonists incorporating an oxime ether functionality. Bioorganic Med. Chem. Lett. 1992, 2, 787-790. [CrossRef]

52. Bromidge, S.M.; Brown, F.; Cassidy, F.; Clark, M.S.G.; Dabbs, S.; Hadley, M.S.; Hawkins, J.; Loudon, J.M.; Naylor, C.B.; Orlek, B.S.; et al. Design of [R-(Z)]-(+)- $\alpha$-(Methoxyimino)-1-azabicyclo[2.2.2]octane-3-acetonitrile (SB 202026), a Functionally Selective Azabicyclic Muscarinic M1 Agonist Incorporating the N-Methoxy Imidoyl Nitrile Group as a Novel Ester Bioisostere. J. Med. Chem. 1997, 40, 4265-4280. [CrossRef] [PubMed]

53. Korczyn, A.D. Muscarinic M1 agonists in the treatment of Alzheimer's disease. Expert Opin. Investig. Drugs 2000, 9, 2259-2267. [CrossRef] [PubMed]

54. Sramek, J.J.; Forrest, M.; Mengel, H.; Jhee, S.S.; Hourani, J.; Cutler, N.R. A Bridging Study of LU 25-109 in Patients with Probably Alzheimer's Disease. Life Sci. 1997, 62, 195-202. [CrossRef]

55. Ono, M.; Takamura, E.; Shinozaki, K.; Tsumura, T.; Hamano, T.; Yagi, Y.; Tsubota, K. Therapeutic effect of cevimeline on dry eye in patients with Sjogren's syndrome: A randomized, double-blind clinical study. Am. J. Ophthalmol. 2004, 138, 6-17. [CrossRef] [PubMed]

56. Sedman, A.J.; Bockbrader, H.; Schwarz, R.D. Preclinical and phase 1 clinical characterization of CI-979/RU35926, a novel muscarinic agonist for the treatment of Alzheimer's diseases. Life Sci. 1995, 56, 877-882. [CrossRef]

57. TorreyPines Therapeutics Muscarinic Agonist NGX267 Meets Primary Endpoint in a Phase II Clinical Trial in Patients with Xerostom. Available online: https://www.fiercebiotech.com/biotech/torreypines-therapeutics-muscarinic-agonist-ngx267 -meets-primary-endpoint-a-phase-ii (accessed on 18 November 2021).

58. Adamus, W.S.; Leonard, J.; Troger, W. Phase I clinical trials with WAL 2014, a new muscarinic agonist for the treatment of Alz-heimer's disease. Life Sci. 1995, 56, 883-890. [CrossRef]

59. Loudon, J.M.; Bromidge, S.M.; Brown, F.; Clark, M.S.G.; Hatcher, J.P.; Hawkins, J.; Riley, G.J.; Noy, G.; Orlek, B.S. SB 202026: A Novel Muscarinic Partial Agonist with Functional Selectivity for M1 Receptors. J. Pharmacol. Exp. Ther. 1997, 283, 1059-1068.

60. Heinrich, J.N.; Butera, J.A.; Carrick, T.; Kramer, A.; Kowal, D.; Lock, T.; Marquis, K.L.; Pausch, M.H.; Popiolek, M.; Sun, S.C.; et al. Pharmacological comparison of muscarinic ligands: Historical versus more recent muscarinic M1-preferring receptor agonists. Eur. J. Pharmacol. 2009, 605, 53-56. [CrossRef]

61. Collingwood, S.P.; Ratcliffe, A.J.; Pryde, D.; Porter, R. Recent disclosures of clinical candidates: Highlights from the Society of Medicines research symposium. Drugs Future 2015, 40, 81-91. [CrossRef]

62. Brown, A.J.H.; Bradley, S.J.; Marshall, F.H.; Brown, G.A.; Bennett, K.A.; Brown, J.; Cansfield, J.E.; Cross, D.M.; De Graaf, C.; Hudson, B.D.; et al. From structure to clinic: Design of a muscarinic M1 receptor agonist with potential to treatment of Alzheimer's disease. Cell 2021, 184, 5886-5901.e22. [CrossRef] [PubMed]

63. Felder, C.C.; Goldsmith, P.; Jackson, K.; Sanger, H.E.; Evans, D.A.; Mogg, A.J.; Broad, L.M. Current status of muscarinic M1 and M4 receptors as drug targets for neurodegenerative diseases. Neuropharmacology 2018, 136, 449-458. [CrossRef] [PubMed]

64. Kulkarni, A.D.; Patel, H.M.; Surana, S.J.; Belgamwar, V.S.; Pardeshi, C.V. Brain-blood ratio: Implications in brain drug delivery. Expert Opin. Drug Deliv. 2016, 13, 85-92. [CrossRef] [PubMed] 
65. Schrage, R.; Seemann, W.; Klöckner, J.; Dallanoce, C.; Racké, K.; Kostenis, E.; De Amici, M.; Holzgrabe, U.; Mohr, K. Agonists with supraphysiological efficacy at the muscarinic M2 ACh receptor. J. Cereb. Blood Flow Metab. 2013, 169, 357-370. [CrossRef]

66. Rajagopal, S.; Ahn, S.; Rominger, D.H.; Gowen-MacDonald, W.; Lam, C.M.; DeWire, S.M.; Violin, J.D.; Lefkowitz, R.J. Quantifying Ligand Bias at Seven-Transmembrane Receptors. Mol. Pharmacol. 2011, 80, 367-377. [CrossRef]

67. Buchwald, P. A Receptor Model With Binding Affinity, Activation Efficacy, and Signal Amplification Parameters for Complex Fractional Response Versus Occupancy Data. Front. Pharmacol. 2019, 10, 605. [CrossRef]

68. Sosei Provides Update on HTL0018318. Available online: https://soseiheptares.com/news/109/129/Sosei-Provides-Update-onHTL0018318.html) (accessed on 1 December 2021).

69. Bakker, C.; Tasker, T.; Liptrot, J.; Hart, E.P.; Klaassen, E.S.; Prins, S.; van der Doef, T.F.; Brown, G.A.; Brown, A.; Congreve, M.; et al. First-in-man study to investigate safety, pharmacokinetics and exploratory pharmacodynamics of HTL0018318, a novel M1 -receptor partial agonist for the treatment of dementias. Br. J. Clin. Pharmacol. 2021, 87, 2945-2955. [CrossRef]

70. Bakker, C.; Tasker, T.; Liptrot, J.; Hart, E.P.; Klaassen, E.S.; Doll, R.J.; Brown, G.A.; Brown, A.; Congreve, M.; Weir, M.; et al. Safety, pharmacokinetics and exploratory pro-cognitive effects of HTL0018318, a selective M1 receptor agonist, in healthy younger adult and elderly subjects: A multiple ascending dose study. Alzheimer's Res. Ther. 2021, 13, 87. [CrossRef]

71. Congreve, M.; Brown, G.; Cansfield, J.; Tehan, B. Muscarinic M1 Receptor Agonists. U.S. Patent WO/2013/072705, 23 May 2013

72. Broad, L.M.; Sanger, H.E.; Mogg, A.J.; Colvin, E.M.; Zwart, R.; Evans, D.A.; Pasqui, F.; Sher, E.; Wishart, G.N.; Barth, V.N.; et al. Identification and pharmacological profile of SPP1, a potent, functionally selective and brain penetrant agonist at mus-carinic M1 receptors. Br. J. Pharmacol. 2019, 176, 110-126. [CrossRef]

73. Clark, A.; Mitchelson, F. The inhibitory effect of gallamine on muscarinic receptors. J. Cereb. Blood Flow Metab. 1976, 58, 323-331. [CrossRef]

74. Fischer, A. Cholingeric treatments with emphasis on M1 muscarinic agonists as potential disease-modifying agents for Alzheimer's disease. Neurotherapeutics 2008, 5, 433-442. [CrossRef]

75. Fisher, A.; Brandeis, R.; Bar-Ner, R.H.; Kliger-Spatz, M.; Natan, N.; Sonego, H.; Marcovitch, I.; Pittel, Z.A. 150(S) and AF267B: M1 muscarinic agonists as innovative therapies for Alzheimer's disease. J. Mol. Neurosci. 2002, 19, 145-153. [CrossRef]

76. Lazareno, S.; Dolezal, V.; Popham, A.; Birdsall, N.J.M. Thiochrome Enhances Acetylcholine Affinity at Muscarinic M4 Receptors: Receptor Subtype Selectivity via Cooperativity Rather than Affinity. Mol. Pharmacol. 2004, 65, 257-266. [CrossRef]

77. Bock, A.; Schrage, R.; Mohr, K. Allosteric modulators targeting CNS muscarinic receptors. Neuropharmacology 2018, 136, 427-437. [CrossRef]

78. Kenakin, T.P.; Beek, D. The effects on Schild regressions of antagonist removal from the receptor compartment by a saturable process. Naunyn-Schmiedebergs Arch. fur Exp. Pathol. Pharmakol. 1987, 335, 103-108. [CrossRef]

79. Proska, J.; Tucek, S. Mechanisms of steric and cooperative actions of alcuronium on cardiac muscarinic acetylcholine receptors Mol. Pharmacol. 1994, 45, 709-717.

80. Tucek, S.; Musilkova, J.; Nedoma, J.; Proska, J.; Shelkovnikov, S.; Vorlícek, J. Positive cooperativity in the binding of alcuronium and N-methylscopolamine to muscarinic acetylcholine receptors. Mol. Pharmacol. 1990, 38, 674-680.

81. Lanzafame, A.; Christopoulos, A.; Mitchelson, F. Three allosteric modulators act a common site, distinct from that of competitive antagonists, at muscarinic acetylcholine M2 receptors. J. Pharmacol. Exp. Ther. 1997, 282, 278-285.

82. Lazareno, S.; Popham, A.; Birdsall, N.J.M. Allosteric Interactions of Staurosporine and Other Indolocarbazoles withN-[methyl3H]Scopolamine and Acetylcholine at Muscarinic Receptor Subtypes: Identification of a Second Allosteric Site. Mol. Pharmacol. 2000, 58, 194-207. [CrossRef]

83. Birdsall, N.J.; Burgen, A.S.; Hulme, E.C.; Stockton, J.M.; Zigmond, M.J. The effect of McN-A-343 on muscarinic receptors in the cerebral cortex and heart. Br. J. Pharmacol. 1983, 78, 257-259. [CrossRef]

84. Waelbroeck, M. Identification of drugs competing with d-tubocurarine for an allosteric site on cardiac muscarinic receptors. Mol. Pharmacol. 1994, 46, 685-692.

85. Mitchelson, F.J. The pharmacology of McN-A-343. Pharmacol. Ther. 2012, 135, 216-245. [CrossRef]

86. Langmead, C.J.; Fry, V.A.; Forbes, I.T.; Branch, C.L.; Christopoulos, A.; Wood, M.D.; Herdon, H.J. Probing the molecular mechanism of interaction between 4-n-butyl-1-[4-(2-methylphenyl)-4-oxo-1-butyl]-piperidine (AC-42) and the muscarinic M1 receptor: Di-rect pharmacological evidence that AC-42 is an allosteric agonist. Mol. Pharmacol. 2006, 69, 236-246. [CrossRef]

87. Spalding, T.A.; Ma, J.N.; Ott, T.R.; Friberg, M.; Bajpai, A.; Bradley, S.R.; Davis, R.E.; Brann, M.R.; Burstein, E.S. Structural requirements of transmembrane domain 3 for activation by the M1 muscarinic receptor agonists AC-42, AC-260584, Clozapine, and N-Desmethylclozapine: Evidence for three distinct modes of receptor activation. Mol. Pharmacol. 2006, 70, 1974-1983. [CrossRef]

88. Bradley, S.R.; Lameh, J.; Ohrmund, L.; Son, T.; Bajpai, A.; Nguyen, D.; Friberg, M.; Burstein, E.S.; Spalding, T.A.; Ott, T.R.; et al. AC-260584, an orally bioavailable M1 muscarinic receptor allosteric agonist, improves cognitive performance in an animal model. Neuropharmacology 2010, 58, 365-373. [CrossRef]

89. Vanover, K.E.; Veinbergs, I.; Davis, R.E. Antipsychotic-like behavioral effects and cognitive enhancement by a potent and selective muscarinic M-sub-1 receptor agonist, AC-260584. Behav. Neurosci. 2008, 122, 570-575. [CrossRef]

90. Langmead, C.J.; Austin, N.E.; Branch, C.L.; Brown, J.T.; Buchanan, K.A.; Davies, C.H.; Forbes, I.T.; Fry, V.A.H.; Hagan, J.J.; Herdon, H.J.; et al. Characterization of a CNS penetrant, selective M1 muscarinic receptor agonist, 77-LH-28-1. Brit. J. Pharmacol. 2008, 154, 1104-1115. [CrossRef] [PubMed] 
91. Jones, C.K.; Brady, A.E.; Bubser, M.; Deutch, A.Y.; Williams, L.C.; Hammond, A.; Willliams, R.; Conn, P.J. TBPB is a highly selective M1 allosteric muscarinic receptor agonist in vitro and produces robust antipsychotic-like effects in vivo. Neuropsychopharmacology 2006, 31, S116.

92. Conn, P.J.; Jones, C.K.; Lindsley, C.W. Subtype-selective allosteric modulators of muscarinic receptors for the treatment of CNS disorders. Trends Pharmacol. Sci. 2009, 30, 148-155. [CrossRef] [PubMed]

93. Ma, L.; Seager, M.A.; Wittmann, M.; Jacobson, M.; Bickel, D.; Burno, M.; Jones, K.; Graufelds, V.K.; Xu, G.; Pearson, M.; et al. Selective activation of the M1 muscarinic acetylcholine receptor achieved by allosteric potentiation. Proc. Natl. Acad. Sci. USA 2009, 106, 15950-15955. [CrossRef] [PubMed]

94. Shirey, J.K.; Brady, A.E.; Jones, P.J.; Davis, A.A.; Bridges, T.M.; Kennedy, J.P.; Jadhav, S.B.; Menon, U.N.; Xiang, Z.; Watson, M.L.; et al. A selective allosteric potentiator of the M1 muscarinic acetylcholine receptor increases activity of medial prefrontal cortical neurons and restores impairments in reversal learning. J. Neurosci. 2009, 29, 14271-14286. [CrossRef]

95. Kuduk, S.D.; Chang, R.K.; Di Marco, C.N.; Ray, W.J.; Ma, L.; Wittmann, M.; Seager, M.A.; Koeplinger, K.A.; Thompson, C.D.; Hartman, G.D.; et al. Quinolizidinone carboxylic acids as CNS penetrant, selective $\mathrm{m} 1$ allosteric mus-carinic receptor modulators. ACS Med. Chem. Lett. 2010, 1, 263-267. [CrossRef]

96. Kuduk, S.D.; Di Marco, C.N.; Chang, R.K.; Ray, W.J.; Ma, L.; Wittmann, M.; Seager, M.A.; Koeplinger, K.A.; Thompson, C.D.; Hartman, G.D.; et al. Heterocyclic fused pyridone carboxylic acid M(1) positive allosteric modulators. Bioorg. Med. Chem. Lett. 2010, 20, 2533-2537. [CrossRef]

97. Kuduk, S.D.; Di Marco, C.N.; Cofre, V.; Pitts, D.R.; Ray, W.J.; Ma, L.; Wittmann, M.; Seager, M.A.; Koeplinger, K.; Thompson, C.D.; et al. Pyridine containing M(1) positive allosteric modulators with reduced plasma protein binding. Bioorg. Med. Chem. Lett. 2010, 20, 657-661. [CrossRef]

98. Kuduk, S.D.; Chang, R.K.; Greshock, T.J.; Ray, W.J.; Ma, L.; Wittmann, M.; Seager, M.A.; Koeplinger, K.A.; Thompson, C.D.; Hartman, G.D.; et al. Identification of Amides as Carboxylic Acid Surrogates for Quinolizidinone-Based M1 Positive Allosteric Modulators. ACS Med. Chem. Lett. 2012, 3, 1070-1074. [CrossRef]

99. Yang, Z.Q.; Shu, Y.; Ma, L.; Wittmann, M.; Ray, W.J.; Seager, M.A.; Koeplinger, K.A.; Thompson, C.D.; Hartman, G.D.; Bilodeau, M.T.; et al. Discovery of naphthyl-fused 5-membered lactams as a new class of m1 positive allosteric mod-ulators. ACS Med. Chem. Lett. 2014, 5, 604-608. [CrossRef]

100. Beshore, D.C.; Di Marco, N.C.; Chang, R.K.; Greshock, T.J.; Ma, L.; Wittmann, M.; Seager, M.A.; Koeplinger, K.A.; Thompson, C.D.; Fuerst, J.; et al. MK-7622: A First-in-Class M1 Positive Allosteric Modulator Development Candidate. ACS Med. Chem. Lett. 2018, 9, 652-656. [CrossRef]

101. Lin, J.H.; Yamazaki, M. Role of P-glycoprotein in pharmacokinetics: Clinical implications. Clin. Pharmacokinet. 2003, 42, 59-98. [CrossRef]

102. Sharom, F.J. Complex Interplay between the P-Glycoprotein Multidrug Efflux Pump and the Membrane: Its Role in Modulating Protein Function. Front Oncol. 2014, 4, 41. [CrossRef]

103. Zhang, Y.; Li, N.; Brown, P.W.; Ozer, J.S.; Lai, Y. Liquid chromatography/tandem mass spectrometry based targeted proteomics quantification of P-glycoprotein in various biological samples. Rapid Commun. Mass Spectrom. 2011, 25, 1715-1724. [CrossRef]

104. Watanabe, R.; Esaki, T.; Ohashi, R.; Kuroda, M.; Kawashima, H.; Komura, H.; Natsume-Kitatani, Y.; Mizuguchi, K. Development of an In Silico Prediction Model for P-glycoprotein Efflux Potential in Brain Capillary Endothelial Cells toward the Prediction of Brain Penetration. J. Med. Chem. 2021, 64, 2725-2738. [CrossRef] [PubMed]

105. Voss, T.; Li, J.; Cummings, J.; Farlow, M.; Assaid, C.; Froman, S.; Leibensperger, H.; Snow-Adami, L.; McMahon, K.B.; Egan, M.; et al. Randomized, controlled, proof-of-concept trial of MK-7622 in Alzheimer's disease. Alzheimer's Dement. 2018, 4, 173-181. [CrossRef] [PubMed]

106. Rook, J.M.; Abe, M.; Cho, H.P.; Nance, K.D.; Luscombe, V.B.; Adams, J.J.; Dickerson, J.W.; Remke, D.H.; Garcia-Barrantes, P.M.; Engers, D.W.; et al. Diverse Effects on M1 Signaling and Adverse Effect Liability within a Series of M1 Ago-PAMs. ACS Chem. Neurosci. 2017, 8, 866-883. [CrossRef] [PubMed]

107. Alt, A.; Pendri, A.; Bertekap, R.L., Jr.; Li, G.; Benitex, Y.; Nophsker, M.; Rockwell, K.L.; Burford, N.T.; Sum, C.S.; Chen, J.; et al. Evidence for Classical Cholinergic Toxicity Associated with Selective Activation of M1 Muscarinic Receptors. J. Pharmacol. Exp. Ther. 2016, 356, 293-304. [CrossRef] [PubMed]

108. Kuduk, S.D.; Beshore, D.C. Novel M1allosteric ligands: A patent review. Expert Opin. Ther. Patents 2012, 22, 1385-1398. [CrossRef] [PubMed]

109. Wold, E.A.; Chen, J.; Cunningham, K.A.; Zhou, J. Allosteric Modulation of Class A GPCRs: Targets, Agents, and Emerging Concepts. J. Med. Chem. 2018, 62, 88-127. [CrossRef] [PubMed]

110. Moran, S.P.; Dickerson, J.W.; Cho, H.P.; Xiang, Z.; Maksymetz, J.; Remke, D.H.; Lv, X.; Doyle, C.A.; Rajan, D.H.; Niswender, C.M.; et al. M1-positive allosteric modulators lacking agonist activity provide the op-timal profile for enhancing cognition. Neuropsychopharmacology 2018, 43, 1763-1771. [CrossRef]

111. Panarese, J.D.; Cho, H.P.; Adams, J.J.; Nance, K.D.; Garcia-Barrantes, P.M.; Chang, S.; Morrison, R.D.; Blobaum, A.L.; Niswender, C.M.; Stauffer, S.R.; et al. Further optimization of the M1 PAM VU0453595: Discovery of novel hetero-bicyclic core motifs with improved CNS penetration. Bioorg Med. Chem. Lett. 2016, 26, 3822-3825. [CrossRef] 
112. Conley, A.C.; Key, A.P.; Blackford, J.U.; Rook, J.M.; Conn, J.; Lindsley, C.W.; Jones, C.K.; Newhouse, P.A. Cognitive performance effects following a single dose of the M 1 muscarinic positive allosteric modulator VU319. Alzheimer's Dement. 2020, 16, e045339. [CrossRef]

113. Newhouse, P.A.; Conley, A.C.; Key, A.P.; Blackford, J.U.; Rook, J.M.; Conn, J.; Lindsley, C.W.; Jones, C.K. Safety and pharmacokinetics of the muscarinic positive allosteric modulator VU319: A phase 1 single dose study. Alchaimer's Dement. 2020, 16, e045359. [CrossRef]

114. Vamvakidès, A. Effets anticonvulsivant et anti-immobilité (nage forcée) de la tétrahydro-N, N-diméthyl-2, 2-diphényl-3furaneméthanamine (AE37) [Anticonvulsant and forced swim anti-immobility effects of tetrahy-dro-N, N-dimethyl-2,2-diphenyl3-furanemethanamine (AE37): Common action mechanism]. Ann. Pharm. Fr. 2002, 60, 88-92.

115. Lahmy, V.; Meunier, J.; Malmström, S.; Naert, G.; Givalois, L.; Kim, S.H.; Villard, V.; Vamvakides, A.; Maurice, T. Blockade of Tau hyperphosphorylation and $\mathrm{A} \beta_{1-42}$ generation by the ami-notetrahydrofuran derivative ANAVEX2-73, a mixed muscarinic and $\sigma_{1}$ receptor agonist, in a nontransgenic mouse model of Alzheimer's disease. Neuropsychopharmacology 2013, 38, 1706-1723. [CrossRef]

116. Villard, V.; Espallergues, J.; Keller, E.; Vamvakides, A.; Maurice, T. Anti-amnesic and neuroprotective potentials of the mixed muscarinic receptor/sigma $1(\sigma 1)$ ligand ANAVEX2-73, a novel aminotetrahydrofuran derivative. J. Psychopharmacol. 2011, 25, 1101-1117. [CrossRef]

117. Lahmy, V.; Long, R.; Morin, D.; Villard, V.; Maurice, T. Mitochondrial protection by the mixed muscarinic/ $\sigma 1$ ligand ANAVEX2-73, a tetrahydrofuran derivative, in A $\beta 25-35$ peptide-injected mice, a nontransgenic Alzheimer's dis-ease model. Front. Cell Neurosci. 2015, 8, 463. [CrossRef]

118. ANAVEX ${ }^{\circledR} 2-73$ (Blarcamesine) Currently in Phase 2b/3 Early Alzheimer's Disease (AD): Analysis of Cognitive Outcome Measures Relevant to AD of Double-Blind, Multicenter, Placebo-Controlled Phase 2 Clinical Trial in 132 Patients with Parkinson's Disease Dementia. Available online: https://www.globenewswire.com/en/news-release/2020/11/06/2122112/29248/en/ Proof-of-Concept-Controlled-Phase-2-Clinical-Trial-Data-Evaluating-ANAVEX-2-73-blarcamesine-in-Parkinson-s-DiseaseDementia-Presented-at-CTAD-2020-Conference.html (accessed on 2 December 2021).

119. Fisher, A.; Bezprozvanny, I.; Wu, L.; Ryskamp, D.A.; Bar-Ner, N.; Natan, N.; Brandeis, R.; Elkon, H.; Nahum, V.; Gershonov, E.; et al. AF710B, a Novel M1/o1 Agonist with Therapeutic Efficacy in Animal Models of Alzheimer's Disease. Neurodegener Dis. 2016, 16, 95-110. [CrossRef]

120. Sako, Y.; Kurimoto, E.; Mandai, T.; Suzuki, A.; Tanaka, M.; Suzuki, M.; Shimizu, Y.; Yamada, M.; Kimura, H. TAK-071, a novel M1 positive allosteric modulator with low cooperativity, im-proves cognitive function in rodents with few cholinergic side effects. Neuropsychopharmacology 2019, 44, 950-960. [CrossRef]

121. Harvard Medical School, Psychiatry Neuroimaging Laboratory. Available online: http://pnl.bwh.harvard.edu/education/whatis/schizophrenia/ (accessed on 3 December 2021).

122. Larson, M.K.; Walker, E.F.; Compton, M.T. Early signs, diagnosis, and therapeutics of the prodromal phase of schizo-phrenia and related psychotic disorders. Expert Rev. Neurother. 2010, 10, 1347-1359. [CrossRef]

123. Andreasen, N.C.; Carpenter, W.T., Jr. Diagnosis and classification of schizophrenia. Schizophr. Bull. 1993, 19, 199-214. [CrossRef]

124. Rook, J.M.; Choi, D.L.; Foster, D.; Conn, P.J. Activation of M1 and M4 muscarinic receptors as potential treatments for Alzheimer's disease and schizophrenia. Neuropsychiatr. Dis. Treat. 2014, 10, 183-191. [CrossRef]

125. Borroni, B.; Costanzi, C.; Padovani, A. Genetic susceptibility to behavioural and psychological symptoms in Alzheimer disease. Curr. Alzheimer Res. 2010, 7, 158-164. [CrossRef]

126. Carlsson, A. The current status of the dopamine hypothesis of schizophrenia. Neuropsychopharmacology 1988, 1, 179-186. [CrossRef]

127. Davis, K.L.; Kahn, R.S.; Ko, G.; Davidson, M. Dopamine in schizophrenia: A review and reconceptualization. Am. J. Psychiatry 1991, 148, 1474-1486. [CrossRef] [PubMed]

128. Howes, O.; Kapur, S. The Dopamine Hypothesis of Schizophrenia: Version III-The Final Common Pathway. Schizophr. Bull. 2009, 35, 549-562. [CrossRef] [PubMed]

129. Sekiguchi, H.; Pavey, G.; Dean, B. Altered levels of dopamine transporter in the frontal pole and dorsal striatum in schizophrenia. npj Schizophr. 2019, 5, 1-8. [CrossRef] [PubMed]

130. Sonnenschein, S.F.; Gomes, F.V.; Grace, A.A. Dysregulation of Midbrain Dopamine System and the Pathophysiology of Schizophrenia. Front. Psychiatry 2020, 11, 613. [CrossRef]

131. Kesby, J.P.; Eyles, D.; McGrath, J.J.; Scott, J. Dopamine, psychosis and schizophrenia: The widening gap between basic and clinical neuroscience. Transl. Psychiatry 2018, 8, 1-12. [CrossRef]

132. Stępnicki, P.; Kondej, M.; Kaczor, A.A. Current Concepts and Treatments of Schizophrenia. Molecules 2018, 23, 2087. [CrossRef]

133. Lieberman, J.A.; Stroup, T.S.; McEvoy, J.P.; Swartz, M.S.; Rosenheck, R.A.; Perkins, D.O.; Keefe, R.S.; Davis, S.M.; Davis, C.E.; Le-bowitz, B.D.; et al. Clinical Antipsychotic Trials of Intervention Effectiveness (CATIE) Investigators. Ef-fectiveness of antipsychotic drugs in patients with chronic schizophrenia. N. Engl. J. Med. 2005, 353, 1209-1223. [CrossRef]

134. Lally, J.; MacCabe, J.H. Antipsychotic medication in schizophrenia: A review. Br. Med. Bull. 2015, 114, 169-179. [CrossRef]

135. Raedler, T.J.; Bymaster, F.P.; Tandon, R.; Copolov, D.; Dea, B. Towards a muscarinic hypothesis of schizophrenia. Mol. Psychiatry 2007, 12, 232-246. [CrossRef]

136. Foster, D.J.; Jones, C.K.; Conn, P.J. Emerging approaches for treatment of schizophrenia: Modulation of cholinergic sig-naling. Discov. Med. 2012, 14, 413-420. 
137. Tomasetti, C.; Iasevoli, F.; Buonaguro, E.F.; De Berardis, D.; Fornaro, M.; Fiengo, A.L.; Martinotti, G.; Orsolini, L.; Valchera, A.; Di Giannantonio, M.; et al. Treating the Synapse in Major Psychiatric Disorders: The Role of Postsynaptic Density Network in Dopamine-Glutamate Interplay and Psychopharmacologic Drugs Molecular Ac-tions. Int. J. Mol. Sci. 2017, 18, 135. [CrossRef]

138. Iasevoli, F.; Tomasetti, C.; Buonaguro, E.F.; de Bartolomeis, A. The Glutamatergic Aspects of Schizophrenia Molecular Pathophysiology: Role of the Postsynaptic Density, and Implications for Treatment. Curr. Neuropharmacol. 2014, 12, 219-238. [CrossRef]

139. De Bartolomeis, A.; Avagliano, C.; Vellucci, L.; D’Ambrosio, L.; Manchia, M.; D’Urso, G.; Buonaguro, E.F.; Iasevoli, F. Translating preclinical findings in clinically relevant new anti-psychotic targets: Focus on the glutamatergic postsynaptic density. Implications for treatment resistant schizophrenia. Neurosci. Biobehav. Rev. 2019, 107, 795-827. [CrossRef]

140. Coyle, J.T.; Basu, A.; Benneyworth, M.; Balu, D.; Konopaske, G. Glutamatergic Synaptic Dysregulation in Schizophrenia: Therapeutic Implications. Nov. Antischizophrenia Treat. 2012, 267-295. [CrossRef]

141. Noetzel, M.J.; Jones, C.K.; Conn, P.J. Emerging approaches for treatment of schizophrenia: Modulation of glutamatergic signaling. Discov. Med. 2012, 14, 335-343.

142. Marín, O. Interneuron dysfunction in psychiatric disorders. Nat. Rev. Neurosci. 2012, 13, 107-120. [CrossRef]

143. Coyle, J.T. Schizophrenia: Basic and Clinical. Neurodegener. Dis. 2017, 15, 255-280. [CrossRef]

144. Perry, E.K.; Perry, R.H. Acetylcholine and hallucinations: Disease-related compared to drug-induced alterations in human con-sciousness. Brain Cogn. 1995, 28, 240-258. [CrossRef]

145. Minzenberg, M.J.; Poole, J.H.; Benton, C.; Vinogradov, S. Association of Anticholinergic Load With Impairment of Complex Attention and Memory in Schizophrenia. Am. J. Psychiatry 2004, 161, 116-124. [CrossRef]

146. Klinkenberg, I.; Blokland, A. The validity of scopolamine as a pharmacological model for cognitive impairment: A review of animal behavioral studies. Neurosci. Biobehav. Rev. 2010, 34, 1307-1350. [CrossRef]

147. Taly, A.; Corringer, P.-J.; Guedin, D.; Lestage, P.; Changeux, J.-P. Nicotinic receptors: Allosteric transitions and therapeutic targets in the nervous system. Nat. Rev. Drug Discov. 2009, 8, 733-750. [CrossRef] [PubMed]

148. Pae, C.-U. Role of the cholinesterase inhibitors in the treatment of schizophrenia. Expert Opin. Investig. Drugs 2013, 22, 293-298. [CrossRef]

149. Ribeiz, S.R.I.; Bassitt, D.P.; Arrais, J.A.; Avila, R.; Steffens, D.C.; Bottino, C.M.C. Cholinesterase Inhibitors as Adjunctive Therapy in Patients with Schizophrenia and Schizoaffective Disorder. CNS Drugs 2010, 24, 303-317. [CrossRef] [PubMed]

150. Thakurathi, N.; Vincenzi, B.; Henderson, D.C. Assessing the prospect of donepezil in improving cognitive impairment in patients with schizophrenia. Expert Opin. Investig. Drugs 2012, 22, 259-265. [CrossRef] [PubMed]

151. McDermott, C.L.; Gray, S.L. Cholinesterase Inhibitor Adjunctive Therapy for Cognitive Impairment and Depressive Symptoms in Older Adults with Depression. Ann. Pharmacother. 2012, 46, 599-605. [CrossRef]

152. Gomeza, J.; Zhang, L.; Kostenis, E.; Felder, C.; Bymaster, F.; Brodkin, J.; Shannon, H.; Xia, B.; Deng, C.-X.; Wess, J. Enhancement of D1 dopamine receptor-mediated locomotor stimulation in M4 muscarinic acetylcholine receptor knockout mice. Proc. Natl. Acad. Sci. USA 1999, 96, 10483-10488. [CrossRef]

153. Miyakawa, T.; Yamada, M.; Duttaroy, A.; Wess, J. Hyperactivity and Intact Hippocampus-Dependent Learning in Mice Lacking the M1Muscarinic Acetylcholine Receptor. J. Neurosci. 2001, 21, 5239-5250. [CrossRef]

154. Koshimizu, H.; Leiter, L.M.; Miyakawa, T. M4 muscarinic receptor knockout mice display abnormal social behavior and decreased prepulse inhibition. Mol. Brain 2012, 5, 10. [CrossRef]

155. Gerber, D.J.; Sotnikova, T.D.; Gainetdinov, R.; Huang, S.Y.; Caron, M.G.; Tonegawa, S. Hyperactivity, elevated dopaminergic transmission, and response to amphetamine in M1 muscarinic acetylcholine receptor-deficient mice. Proc. Natl. Acad. Sci. USA 2001, 98, 15312-15317. [CrossRef]

156. Dean, B.; Hopper, S.; Conn, P.J.; Scarr, E. Changes in BQCA Allosteric Modulation of [3H]NMS Binding to Human Cortex within Schizophrenia and by Divalent Cations. Neuropsychopharmacology 2015, 41, 1620-1628. [CrossRef]

157. Tzavara, E.T.; Bymaster, F.P.; Davis, R.J.; Wade, M.R.; Perry, K.W.; Wess, J.; McKinzie, D.L.; Felder, C.; Nomikos, G.G. M4 muscarinic re-ceptors regulate the dynamics of cholinergic and dopaminergic neurotransmission: Relevance to the pathophysiology and treatment of related CNS pathologies. FASEB J. 2004, 18, 1410-1412. [CrossRef]

158. Jeon, J.; Dencker, D.; Wörtwein, G.; Woldbye, D.P.D.; Cui, Y.; Davis, A.A.; Levey, A.I.; Schütz, G.; Sager, T.N.; Mørk, A.; et al. A Subpopulation of Neuronal M4 Muscarinic Acetylcholine Receptors Plays a Critical Role in Modulating Dopamine-Dependent Behaviors. J. Neurosci. 2010, 30, 2396-2405. [CrossRef]

159. Nair, A.; Castro, L.R.V.; El Khoury, M.; Gorgievski, V.; Giros, B.; Tzavara, E.T.; Hellgren-Kotaleski, J.; Vincent, P. The high efficacy of muscarinic M4 receptor in D1 medium spiny neurons reverses striatal hyperdopaminergia. Neuropharmacology 2018, 146, 74-83. [CrossRef]

160. Hopper, S.; Udawela, M.; Scarr, E.; Dean, B. Allosteric modulation of cholinergic system: Potential approach to treating cognitive deficits of schizophrenia. World J. Pharmacol. 2016, 5, 1. [CrossRef]

161. Crook, J.M.; Tomaskovic-Crook, E.; Copolov, D.L.; Dean, B. Low muscarinic receptor binding in prefrontal cortex from subjects with schizophrenia: A study of Brodmann's areas 8, 9, 10, and 46 and the effects of neuroleptic drug treatment. Am. J. Psychiatry 2001, 158, 918-925. [CrossRef]

162. Zavitsanou, K.; Katsifis, A.; Mattner, F.; Huang, X.F. Investigation of M1/M4 muscarinic receptors in the anterior cingulate cortex in schizophrenia, bipolar, disorder, and major depression disorder. Neuropsychopharmacology 2004, 29, 619-625. [CrossRef] 
163. Crook, J.M.; Tomaskovic-Crook, E.; Copolov, D.L.; Dean, B. Decreased muscarinic receptor binding in subjects with schizophrenia: A study of the human hippocampal formation. Biol. Psychiatry 2000, 48, 381-388. [CrossRef]

164. Dean, B.; Crook, J.M.; Opeskin, K.; Hill, C.; Keks, N.; Copolov, D.L. The density of muscarinic M1 receptors is decreased in the cau-date-putamen of subjects with schizophrenia. Mol Psychiatry 1996, 1, 54-58.

165. Raedler, T.J.; Knable, M.B.; Jones, D.W.; Urbina, R.A.; Gorey, J.G.; Lee, K.S.; Egan, M.F.; Coppola, R.; Weinberger, D.R. In vivo determination of muscarinic acetylcholine receptor availability in schizophrenia. Am. J. Psychiatry 2003, 160, 118-127. [CrossRef]

166. Dean, B.; Scarr, E. Muscarinic M1 and M4 receptors: Hypothesis driven drug development for schizophrenia. Psychiatry Res. 2020, 288, 112989. [CrossRef] [PubMed]

167. Dean, B.; McLeod, M.; Keriakous, D.; McKenzie, J.; Scarr, E. Decreased muscarinic1 receptors in the dorsolateral prefrontal cortex of subjects with schizophrenia. Mol. Psychiatry 2002, 7, 1083-1091. [CrossRef] [PubMed]

168. Scarr, E.; Sundram, S.; Keriakous, D.; Dean, B. Altered Hippocampal Muscarinic M4, but Not M1, Receptor Expression from Subjects with Schizophrenia. Biol. Psychiatry 2007, 61, 1161-1170. [CrossRef] [PubMed]

169. Scarr, E.; Craig, J.M.; Cairns, M.J.; Seo, M.S.; Galati, J.C.; Beveridge, N.J.; Gibbons, A.; Juzva, S.; Weinrich, B.; Parkinson-Bates, M.; et al. Decreased cortical muscarinic M1 receptors in schizophrenia are associated with changes in gene promoter methylation, mRNA and gene targeting microRNA. Transl. Psychiatry 2013, 3, e230. [CrossRef]

170. Scarr, E.; Um, J.Y.; Cowie, T.F.; Dean, B. Cholinergic muscarinic M4 receptor gene polymorphisms: A potential risk factor and pharmacogenomic marker for schizophrenia. Schizophr. Res. 2013, 146, 279-284. [CrossRef]

171. Salah-Uddin, H.; Scarr, E.; Pavey, G.; Harris, K.; Hagan, J.J.; Dean, B.; Challiss, R.A.; Watson, J.M. Altered M(1) muscarinic acetylcholine receptor (CHRM1)-Galpha(q/11) coupling in a schizophrenia endophenotype. Neuropsychopharmacology 2009, 34, 2156-2166. [CrossRef]

172. Scarr, E.; Cowie, T.F.; Kanellakis, S.; Sundram, S.; Pantelis, C.; Dean, B. Decreased cortical muscarinic receptors define a subgroup of subjects with schizophrenia. Mol. Psychiatry 2008, 14, 1017-1023. [CrossRef]

173. Scarr, E.; Udawela, M.; Thomas, A.E.; Dean, B. Changed gene expression in subjects with schizophrenia and low cortical muscarinic M1 receptors predicts disrupted upstream pathways interacting with that receptor. Mol. Psychiatry 2016, 23, 295-303. [CrossRef]

174. Hopper, S.; Pavey, G.M.; Gogos, A.; Dean, B.; Udawela, M.; Conn, P.J. Widespread Changes in Positive Allosteric Modulation of the Muscarinic M1 Receptor in Some Participants with Schizophrenia. Int. J. Neuropsychopharmacol. 2019, 22, 640-650. [CrossRef]

175. Bymaster, F.P.; Whitesiit, C.A.; Shannon, H.E.; DeLapp, N.; Ward, J.S.; Calligaro, D.O.; Shipley, L.A.; Buelke-Sam, J.L.; Bodick, N.C.; Farde, L.; et al. Xanomeline: A selective muscarinic agonist for the treatment of Alzheimer's Disease. Drug Dev. Res. 1997, 40, 158-170. [CrossRef]

176. Targum, S.D.; Murphy, C.; Breier, A.; Brannan, S.K. Site-independent confirmation of primary site-based PANSS ratings in a schizophrenia trial. J. Psychiatr. Res. 2021, 144, 241-246. [CrossRef]

177. Brannan, S.K.; Sawchak, S.; Miller, A.C.; Lieberman, J.A.; Paul, S.M.; Breier, A. Muscarinic Cholinergic Receptor Agonist and Peripheral Antagonist for Schizophrenia. N. Engl. J. Med. 2021, 384, 717-726. [CrossRef]

178. Sumiyoshi, T.; Enomoto, T.; Takai, K.; Takahashi, Y.; Konishi, Y.; Uruno, Y.; Tojo, K.; Suwa, A.; Matsuda, H.; Nakako, T.; et al Discovery of novel $\mathrm{N}$-substituted oxindoles as selective M1 and M4 muscarinic acetylcholine re-ceptors partial agonists. ACS Med. Chem. Lett. 2013, 4, 244-248. [CrossRef]

179. Uruno, Y.; Konishi, Y.; Suwa, A.; Takai, K.; Tojo, K.; Nakako, T.; Sakai, M.; Enomoto, T.; Matsuda, H.; Kitamura, A.; et al. Discovery of dihydroquinazolinone derivatives as potent, selective, and CNS-penetrant M1 and M4 muscarinic acetylcholine receptors agonists. Bioorg. Med. Chem. Lett. 2015, 25, 5357-5361. [CrossRef]

180. Suwa, A.; Konishi, Y.; Uruno, Y.; Takai, K.; Nakako, T.; Sakai, M.; Enomoto, T.; Ochi, Y.; Matsuda, H.; Kitamura, A.; et al. Discovery of N-sulfonyl-7-azaindoline derivatives as potent, orally available and selective M4 muscarinic ac-etylcholine receptor agonists. Bioorg. Med. Chem. Lett. 2014, 24, 2909-2912. [CrossRef]

181. Yang, Q.; Lachapelle, E.A.; Kablaoui, N.M.; Webb, D.; Popiolek, M.; Grimwood, S.; Kozak, R.; O'Connor, R.E.; Lazzaro, J.T.; Butler, C.R.; et al. Discovery of Selective M4 Muscarinic Acetylcholine Receptor Agonists with Novel Carbamate Isosteres. ACS Med. Chem. Lett. 2019, 10, 941-948. [CrossRef]

182. Chan, W.Y.; McKinzie, D.L.; Bose, S.; Mitchell, S.N.; Witkin, J.M.; Thompson, R.C.; Christopoulos, A.; Lazareno, S.; Birdsall, N.J.M.; Bymaster, F.P.; et al. Allosteric modulation of the muscarinic M4 receptor as an approach to treating schizophrenia. Proc. Natl. Acad. Sci. USA 2008, 105, 10978-10983. [CrossRef]

183. Leach, K.; Loiacono, E.R.; Felder, C.C.; McKinzie, D.L.; Mogg, A.; Shaw, D.B.; Sexton, P.M.; Christopoulos, A. Molecular Mechanisms of Action and In Vivo Validation of an M4 Muscarinic Acetylcholine Receptor Allosteric Modulator with Potential Antipsychotic Properties. Neuropsychopharmacology 2009, 35, 855-869. [CrossRef]

184. Suratman, S.; Leach, K.; Sexton, P.; Felder, C.; Loiacono, R.; Christopoulos, A. Impact of species variability and 'probe-dependence' on the detection and in vivo validation of allosteric modulation at the M4 muscarinic acetylcholine receptor. J. Cereb. Blood Flow Metab. 2010, 162, 1659-1670. [CrossRef]

185. Croy, C.H.; Schober, D.A.; Xiao, H.; Quets, A.; Christopoulos, A.; Felder, C.C. Characterization of the Novel Positive Allosteric Modulator, LY2119620, at the Muscarinic M2and M4Receptors. Mol. Pharmacol. 2014, 86, 106-115. [CrossRef] 
186. Shirey, J.K.; Xiang, Z.; Orton, D.; Brady, E.A.; Johnson, K.A.; Williams, R.; Ayala, E.J.; Rodriguez, A.L.; Wess, J.; Weaver, D.; et al. An allosteric potentiator of M4 mAChR modulates hippocampal synaptic transmission. Nat. Chem. Biol. 2007, 4, 42-50. [CrossRef] [PubMed]

187. Kennedy, J.P.; Bridges, T.M.; Gentry, P.R.; Brogan, J.T.; Kane, A.S.; Jones, C.K.; Brady, A.E.; Shirey, J.K.; Conn, P.J.; Lindsley, C.W. Synthesis and Structure-Activity Relationships of Allosteric Potentiators of the M4Muscarinic Acetylcholine Receptor. ChemMedChem 2009, 4, 1600-1607. [CrossRef]

188. Brady, A.E.; Jones, C.K.; Bridges, T.M.; Kennedy, J.P.; Thompson, A.D.; Heiman, J.U.; Breininger, M.L.; Gentry, P.R.; Yin, H.; Jadhav, S.B.; et al. Centrally Active Allosteric Potentiators of the M4 Muscarinic Acetylcholine Receptor Reverse AmphetamineInduced Hyperlocomotor Activity in Rats. J. Pharmacol. Exp. Ther. 2008, 327, 941-953. [CrossRef] [PubMed]

189. Byun, N.E.; Grannan, M.; Bubser, M.; Barry, R.L.; Thompson, A.; Rosanelli, J.; Gowrishankar, R.; Kelm, N.D.; Damon, S.; Bridges, T.M.; et al. Antipsychotic Drug-Like Effects of the Selective M4 Muscarinic Acetylcholine Receptor Positive Allosteric Modulator VU0152100. Neuropsychopharmacology 2014, 39, 1578-1593. [CrossRef] [PubMed]

190. Bridges, T.M.; Niswender, C.M.; Jones, C.K.; Lewis, L.M.; Weaver, C.D.; Wood, M.R.; Daniels, J.S.; Conn, J.; Lindsley, C.W. Discovery of a Highly Selective in vitro and in vivo M4 Positive Allosteric Modulator (PAM) Series with Greatly Improved Human Receptor Activity. 2010 Aug 31 [Updated 2013 Mar 14]. In Probe Reports from the NIH Molecular Libraries Program [Internet]; National Center for Biotechnology Information: Bethesda, MD, USA, 2010. Available online: https://www.ncbi.nlm.nih.gov/ books/NBK143196/ (accessed on 4 December 2021).

191. Le, U.; Melancon, B.J.; Bridges, T.M.; Vinson, P.N.; Utley, T.J.; Lamsal, A.; Rodriguez, A.L.; Venable, D.; Sheffler, D.J.; Jones, C.K.; et al. Discovery of a selective M4 positive allosteric modulator based on the 3-amino-thieno[2,3-b]pyridine-2carboxamide scaffold: Development of ML253, a potent and brain penetrant compound that is active in a preclinical model of schizophrenia. Bioorganic Med. Chem. Lett. 2012, 23, 346-350. [CrossRef]

192. Wood, M.R.; Noetzel, M.J.; Poslusney, M.S.; Melancon, B.J.; Tarr, J.C.; Lamsal, A.; Chang, S.; Luscombe, V.B.; Weiner, R.L.; Cho, H.P.; et al. Challenges in the development of an M 4 PAM in vivo tool compound: The discovery of VU0467154 and unexpected DMPK profiles of close analogs. Bioorganic Med. Chem. Lett. 2016, 27, 171-175. [CrossRef] [PubMed]

193. Wood, M.R.; Noetzel, M.J.; Melancon, B.J.; Poslusney, M.S.; Nance, K.D.; Hurtado, M.A.; Luscombe, V.B.; Weiner, R.L.; Rodriguez, A.L.; Lamsal, A.; et al. Discovery of VU0467485/AZ13713945: An M4 PAM Evaluated as a Preclinical Candidate for the Treatment of Schizophrenia. ACS Med. Chem. Lett. 2016, 8, 233-238. [CrossRef] [PubMed]

194. Salovich, J.M.; Vinson, P.N.; Sheffler, D.J.; Lamsal, A.; Utley, T.J.; Blobaum, A.L.; Bridges, T.M.; Le, U.; Jones, C.K.; Wood, M.R.; et al Discovery of N-(4-methoxy-7-methylbenzo[d]thiazol-2-yl)isonicatinamide, ML293, as a novel, selective and brain penetrant positive allosteric modulator of the muscarinic 4 (M4) receptor. Bioorganic Med. Chem. Lett. 2012, 22, 5084-5088. [CrossRef]

195. Wood, M.R.; Noetzel, M.J.; Engers, J.L.; Bollinger, K.A.; Melancon, B.J.; Tarr, J.C.; Han, C.; West, M.; Gregro, A.R.; Lamsal, A.; et al. Discovery and optimization of a novel series of highly CNS penetrant M4 PAMs based on a 5,6-dimethyl-4-(piperidin-1yl)thieno[2,3-d]pyrimidine core. Bioorganic Med. Chem. Lett. 2016, 26, 3029-3033. [CrossRef]

196. Engers, J.L.; Bender, A.M.; Kalbfleisch, J.J.; Cho, H.P.; Lingenfelter, K.S.; Luscombe, V.B.; Han, C.; Melancon, B.J.; Blobaum, A.L.; Dickerson, J.W.; et al. Discovery of Tricyclic Triazolo- and Imidazopyridine Lactams as M1 Positive Allosteric Modulators. ACS Chem. Neurosci. 2018, 10, 1035-1042. [CrossRef]

197. Schubert, J.W.; Harrison, S.T.; Mulhearn, J.; Gomez, R.; Tynebor, R.; Jones, K.; Bunda, J.; Hanney, B.; Wai, J.M.; Cox, C.; et al. Discovery, Optimization, and Biological Characterization of 2,3,6-Trisubstituted Pyridine-Containing M4 Positive Allosteric Modulators. ChemMedChem 2019, 14, 943-951. [CrossRef]

198. Tong, L.; Li, W.; Lo, M.M.; Gao, X.; Wai, J.M.; Rudd, M.; Tellers, D.; Joshi, A.; Zeng, Z.; Miller, P.; et al. Discovery of [11C]MK-6884: A Positron Emission Tomography (PET) Imaging Agent for the Study of M4 Muscarinic Receptor Positive Allosteric Modulators (PAMs) in Neurodegenerative Dis-eases. J. Med. Chem. 2020, 63, 2411-2425. [CrossRef]

199. Mazola, R. Moving Chemistry From Bench to Market. In Proceedings of the Fall 2020 ACS National Meeting (in Part), Virtual meeting, online, 17-20 August 2020.

200. Marino, M.J.; Rouse, S.T.; Levey, A.I.; Potter, L.T.; Conn, P.J. Activation of the genetically defined m1 muscarinic receptor potentiates N-methyl-D-aspartate (NMDA) receptor currents in hippocampal pyramidal cells. Proc. Natl. Acad. Sci. USA 1998, 95 11465-11470. [CrossRef]

201. Marinò, M.; Conn, P. Direct and Indirect Modulation of the N-Methyl D-Aspartate Receptor: Potential for the Development of Novel Antipsychotic Therapies. Curr. Drug Target. -CNS Neurol. Disord. 2002, 1, 1-16. [CrossRef]

202. Digby, G.J.; Noetzel, M.J.; Bubser, M.; Utley, T.J.; Walker, A.G.; Byun, N.E.; Lebois, E.P.; Xiang, Z.; Sheffler, D.J.; Cho, H.P.; et al. Novel allosteric agonists of M1 muscarinic acetylcholine receptors induce brain re-gion-specific responses that correspond with behavioral effects in animal models. J. Neurosci. 2012, 32, 8532-8544. [CrossRef]

203. Ghoshal, A.; Rook, J.M.; Dickerson, J.W.; Roop, G.N.; Morrison, R.D.; Jalansakrikar, N.; Lamsal, A.; Noetzel, M.J.; Poslusney, M.S.; Wood, M.R.; et al. Potentiation of M1 Muscarinic Receptor Reverses Plasticity Deficits and Negative and Cognitive Symptoms in a Schizophrenia Mouse Model. Neuropsychopharmacology 2015, 41, 598-610. [CrossRef]

204. Grannan, M.D.; Mielnik, C.A.; Moran, S.P.; Gould, R.W.; Ball, J.; Lu, Z.; Bubser, M.; Ramsey, A.J.; Abe, M.; Cho, H.P.; et al Prefrontal Cortex-Mediated Impairments in a Genetic Model of NMDA Receptor Hypofunction Are Reversed by the Novel M1 PAM VU6004256. ACS Chem. Neurosci. 2016, 7, 1706-1716. [CrossRef] 
205. Sur, C.; Mallorga, P.J.; Wittmann, M.; Jacobson, M.A.; Pascarella, D.; Williams, J.B.; Brandish, P.E.; Pettibone, D.J.; Scolnick, E.M.; Conn, P.J. N-desmethylclozapine, an allosteric agonist at muscarinic 1 receptor, potentiates N-methyl-D-aspartate receptor activity. Proc. Natl. Acad. Sci. USA 2003, 100, 13674-13679. [CrossRef]

206. Uslaner, J.M.; Eddins, D.; Puri, V.; Cannon, C.E.; Sutcliffe, J.; Chew, C.S.; Pearson, M.; Vivian, J.A.; Chang, R.K.; Ray, W.J.; et al. The muscarinic M1 receptor positive allosteric modulator PQCA improves cognitive measures in rat, cynomolgus ma-caque, and rhesus macaque. Psychopharmacology 2013, 225, 21-30. [CrossRef]

207. Lange, H.S.; Cannon, C.E.; Drott, J.T.; Kuduk, S.D.; Uslaner, J.M. The M1 Muscarinic Positive Allosteric Modulator PQCA Improves Performance on Translatable Tests of Memory and Attention in Rhesus Monkeys. J. Pharmacol. Exp. Ther. 2015, 355, 442-450. [CrossRef]

208. Davoren, J.E.; O’Neil, S.V.; Anderson, D.P.; Brodney, M.A.; Chenard, L.; Dlugolenski, K.; Edgerton, J.R.; Green, M.; Garnsey, M.; Grimwood, S.; et al. Design and optimization of selective azaindole amide M1 positive allosteric modulators. Bioorg. Med. Chem. Lett. 2016, 26, 650-655. [CrossRef]

209. Davoren, J.E.; Lee, C.W.; Garnsey, M.; Brodney, M.A.; Cordes, J.; Dlugolenski, K.; Edgerton, J.R.; Harris, A.R.; Helal, C.J.; Jenkinson, S.; et al. Discovery of the Potent and Selective M1 PAM-Agonist N-[(3R,4S)-3-Hydroxytetrahydro-2H-pyran-4-yl]-5methyl-4-[4-(1,3-thiazol-4-yl)benzyl]pyridine-2-carboxamide (PF-06767832): Evaluation of Efficacy and Cholinergic Side Effects. J. Med. Chem. 2016, 59, 6313-6328. [CrossRef]

210. Hosp, J.A.; Luft, A.R. Dopaminergic Meso-Cortical Projections to M1: Role in Motor Learning and Motor Cortex Plasticity. Front. Neurol. 2013, 4, 145. [CrossRef]

211. Janowsky, D.; Davis, J.; El-Yousef, M.; Sekerke, H. A cholinergic-adrenergic hypothesis of mania and depression. Lancet 1972, 300, 632-635. [CrossRef]

212. Dilsaver, S.C. Cholinergic mechanisms in depression. Brain Res. Rev. 1986, 11, 285-316. [CrossRef]

213. Dagyte, G.; Boer, J.A.D.; Trentani, A. The cholinergic system and depression. Behav. Brain Res. 2011, 221, 574-582. [CrossRef] [PubMed]

214. Janowsky, D.S.; El-Yousef, M.K.; Davis, J.M. Acetylcholine and depression. Psychosom. Med. 1974, 36, 248-257. [CrossRef]

215. Risch, S.C.; Kalin, N.H.; Janowsky, D.S. Cholinergic challenges in affective illness: Behavioral and neuroendocrine correlates. J. Clin. Psychopharmacol. 1981, 1, 186-192. [CrossRef] [PubMed]

216. Nurnberger, J.I., Jr.; Jimerson, D.C.; Simmons-Alling, S.; Tamminga, C.; Nadi, N.S.; Lawrence, D.; Sitaram, N.; Gillin, J.C.; Gershon, E.S. Behavioral, physiological, and neuroendocrine responses to arecoline in normal twins and "well state" bipolar patients. Psychiatry Res. 1983, 9, 191-200. [CrossRef]

217. Sunderland, T.; Tariot, P.N.; Newhouse, P.A. Differential responsivity of mood, behavior, and cognition to cholinergic agents in elderly neuropsychiatric populations. Brain Res. 1988, 472, 371-389. [CrossRef]

218. Davis, K.L.; Hollander, E.; Davidson, M.; Davis, B.M.; Mohs, R.C.; Horvath, T.B. Induction of depression with oxotremorine in patients with Alzheimer's disease. Am. J. Psychiatry 1987, 144, 468-471. [CrossRef]

219. Janowsky, D.S.; Risch, S.C.; Kennedy, B.; Ziegler, M.; Huey, L. Central muscarinic effects of physostigmine on mood, cardiovascular function, pituitary and adrenal neuroendocrine release. Psychopharmacology 1986, 89, 150-154. [CrossRef]

220. Riemann, D.; Hohagan, F.; Bahro, M.; Lis, S.; Stadmuller, G.; Gann, H.; Berger, M. Cholinergic neurotransmission, REM sleep and depression. J. Psychosom. Res. 1994, 38 (Suppl. 1), 15-25. [CrossRef]

221. Poland, R.E.; Tondo, L.; Rubin, R.T.; Trelease, R.B.; Lesser, I.M. Differential effects of scopolamine on nocturnal cortisol secretion, sleep architecture, and REM latency in normal volunteers: Relation to sleep and cortisol abnormalities in depression. Biol. Psychiatry 1989, 25, 403-412. [CrossRef]

222. Sagales, T.; Erill, S.; Domino, E.F. Differential effects of scopolamine and chlorpromazine on REM and NREM sleep in normal male subjects. Clin. Pharmacol. Ther. 1969, 10, 522-529. [CrossRef]

223. Cannon, D.M.; Klaver, J.K.; Gandhi, S.K.; Solorio, G.; Peck, S.A.; Erikson, K.; Savitz, J.; Akula, N.; Eckelman, W.C.; Furey, M.L.; et al Genetic variation in cholinergic muscarinic-2 receptor gene modulates M2 receptor binding in vivo and accounts for reduced binding in bipolar disorder. Mol. Psychiatry 2011, 16, 407-418. [CrossRef]

224. Comings, D.E.; Wu, S.; Rostamkhani, M.; McGue, M.; Iacono, W.G.; MacMurray, J.P. Association of the muscarinic cho-linergic 2 receptor (CHRM2) gene with major depression in women. Am. J. Med. Genet. 2002, 114, 527-529. [CrossRef]

225. Wang, J.C.; Hinrichs, A.L.; Stock, H.; Budde, J.; Allen, R.; Bertelsen, S.; Kwon, J.M.; Wu, W.; Dick, D.M.; Rice, J.; et al. Evidence of common and specific genetic effects: Association of the muscarinic acetylcholine receptor M2 (CHRM2) gene with alcohol dependence and major depressive syndrome. Hum. Mol. Genet. 2004, 13, 1903-1911. [CrossRef]

226. Riemann, D.; Hohagen, F.; Bahro, M.; Berger, M. Sleep in depression: The influence of age, gender and diagnostic subtype on baseline sleep and the cholinergic REM induction test with RS 86. Eur. Arch. Psychiatry Clin. Neurosci. 1994, 243, $279-290$. [CrossRef]

227. Rubin, R.T.; O'Toole, S.M.; Rhodes, M.E.; Sekula, L.; Czambel, R. Hypothalamo-pituitary-adrenal cortical responses to low-dose physostigmine and arginine vasopressin administration: Sex differences between major depressives and matched control subjects. Psychiatry Res. 1999, 89, 1-20. [CrossRef]

228. Luo, X.; Kranzler, H.R.; Zuo, L.; Wang, S.; Blumberg, H.P.; Gelernter, J. CHRM2 gene predisposes to alcohol dependence, drug de-pendence and affective disorders: Results from an extended case-control structured association study. Hum. Mol. Genet. 2005, 14, 2421-2434. [CrossRef] [PubMed] 
229. Shi, J.; Hattori, E.; Zou, H.; Badner, J.A.; Christian, S.L.; Gershon, E.S.; Liu, C. No evidence for association between 19 cholinergic genes and bipolar disorder. Am. J. Med. Genet. Part. B Neuropsychiatr. Genet. 2007, 144B, 715-723. [CrossRef] [PubMed]

230. Cohen-Woods, S.; Gaysina, D.; Craddock, N.; Farmer, A.; Gray, J.; Gunasinghe, C.; Hoda, F.; Jones, L.; Knight, J.; Korszun, A.; et al Depression Case Control (DeCC) Study fails to support involvement of the muscarinic acetylcholine receptor M2 (CHRM2) gene in recurrent major depressive disorder. Hum. Mol. Genet. 2009, 18, 1504-1509. [CrossRef] [PubMed]

231. Scarr, E. Muscarinic receptors in psychiatric disorders-can we mimic 'health'? Neurosignals 2009, 17, 298-310. [CrossRef]

232. Gibbons, A.; Scarr, E.; McLean, C.; Sundram, S.; Dean, B. Decreased muscarinic receptor binding in the frontal cortex of bipolar disorder and major depressive disorder subjects. J. Affect. Disord. 2009, 116, 184-191. [CrossRef]

233. El Yacoubi, M.; Bouali, S.; Popa, D.; Naudon, L.; Leroux-Nicollet, I.; Hamon, M.; Costentin, J.; Adrien, J.; Vaugeois, J. Behavioral, neu-rochemical, and electrophysiological characterization of a genetic mouse model of depression. Proc. Natl. Acad. Sci. USA 2003, 100, 6227-6232. [CrossRef]

234. Overstreet, D.H.; Russell, R.W.; Hay, D.A.; Crocker, A.D. Selective breeding for increased cholinergic function: Biometrical genetic analysis of muscarinic responses. Neuropsychopharmacology 1992, 7, 197-204.

235. Dulawa, S.C.; Janowsky, D.S. Cholinergic regulation of mood: From basic and clinical studies to emerging therapeutics. Mol. Psychiatry 2018, 24, 694-709. [CrossRef]

236. Delgado, P.L. Depression: The case for a monoamine deficiency. J. Clin. Psychiatry 2000, 61, 7-11.

237. Glennon, R.A.; Iversen, L. Burger's Medicinal Chemistry and Drug Discovery, 8th ed.; Elsevier: Amsterdam, The Netherlands, 2020.

238. El-Fakahany, E.; Richelson, E. Antagonism by antidepressants of muscarinic acetylcholine receptors of human brain. J. Cereb. Blood Flow Metab. 1983, 78, 97-102.

239. Siafis, S.; Papazisis, G. Detecting a potential safety signal of antidepressants and type 2 diabetes: A pharmacovigi-lancepharmacodynamic study. Br. J. Clin. Pharmacol. 2018, 84, 2405-2414. [CrossRef]

240. Rathbun, R.C.; Slater, I.H. Amitriptyline and nortriptyline as antagonists of central and peripheral cholinergic activation. Psychopharmacology 1963, 4, 114-125. [CrossRef]

241. Rawls, S.M.; Mcginty, J.F.; Anderson, I.M. SSRIS versus tricyclic antidepressants in depressed inpatients: A meta-analysis of efficacy and tolerability. Depress. Anxiety 1998, 7 (Suppl. 1), 11-17.

242. Deisenhammer, E.A.; Whitworth, A.B.; Geretsegger, C.; Kurzthaler, I.; Gritsch, S.; Miller, C.H.; Fleischhacker, W.W.; Stuppäck, C.H. Intravenous Versus Oral Administration of Amitriptyline in Patients with Major Depression. J. Clin. Psychopharmacol. 2000, 20, 417-422. [CrossRef]

243. Davis, K.L.; Berger, P.A.; Hollister, L.E.; Defraites, E. Physostigmine in Mania. Arch. Gen. Psychiatry 1978, 35, 119-122. [CrossRef]

244. Fava, M. Diagnosis and definition of treatment-resistant depression. Biol. Psychiatry 2003, 53, 649-659. [CrossRef]

245. Trivedi, M.H.; Rush, A.J.; Wisniewski, S.R.; Nierenberg, A.A.; Warden, D.; Ritz, L.; Norquist, G.; Howland, R.H.; Lebowitz, B.; McGrath, P.J.; et al. Evaluation of outcomes with citalopram for depression using measurement-based care in STAR ${ }^{*}$ : Implications for clinical practice. Am. J. Psychiatry 2006, 163, 28-40. [CrossRef]

246. Warden, D.; Rush, A.; Trivedi, M.H.; Fava, M.; Wisniewski, S. The STAR*D project results: A comprehensive review of findings. Curr. Psychiatry Rep. 2007, 9, 449-459. [CrossRef]

247. Blair, D.T.; Dauner, A. Extrapyramidal Symptoms Are Serious Side-effects of Antipsychotic and Other Drugs. Nurse Pr. 1992, 17, 56, 62-64, 67. [CrossRef]

248. Sayyah, M.; Eslami, K.; AlaiShehni, S.; Kouti, L. Cognitive Function before and during Treatment with Selective Serotonin Reuptake Inhibitors in Patients with Depression or Obsessive-Compulsive Disorder Cognitive Function before and during Treatment with Selective Serotonin Reuptake Inhibitors in Patients with Depression or Obsessive-Compulsive Disorder. Psychiatry J. 2016, 2016, 5480391.

249. Fava, M.; Graves, L.M.; Benazzi, F.; Scalia, M.J.; Iosifescu, D.V.; Alpert, J.; Papakostas, G.I. A Cross-Sectional Study of the Prevalence of Cognitive and Physical Symptoms During Long-Term Antidepressant Treatment. J. Clin. Psychiatry 2006, 67, 1754-1759. [CrossRef]

250. Schatzberg, A.F.; Blier, P.; Delgado, P.L.; Fava, M.; Haddad, P.; Shelton, R.C. Antidepressant discontinuation syndrome: Consensus panel recommendations for clinical management and additional research. J. Clin. Psychiatry 2006, 67, 27-30.

251. Shelton, R.C. The nature of the discontinuation syndrome associated with antidepressant drugs. J. Clin. Psychiatry 2006, 67, 3-7.

252. Gray, S.L.; Anderson, M.L.; Dublin, S.; Hanlon, J.T.; Hubbard, R.; Walker, R.; Yu, O.; Crane, P.K.; Larson, E.B. Cumulative use of strong anticholinergics and incident dementia: A prospective cohort study. JAMA Intern Med. 2015, 175, 401-407. [CrossRef] [PubMed]

253. Jessen, F.; Kaduszkiewicz, H.; Daerr, M.; Bickel, H.; Pentzek, M.; Riedel-Heller, S.; Wagner, M.; Weyerer, S.; Wiese, B.; van den Bussche, H.; et al. Anticholinergic drug use and risk for de-mentia: Target for dementia prevention. Eur. Arch. Psychiatry Clin. Neurosci. 2010, 260 (Suppl. 2), S111-S115. [CrossRef] [PubMed]

254. Coupland, C.A.C.; Hill, T.; Dening, T.; Morriss, R.; Moore, M.; Hippisley-Cox, J. Anticholinergic Drug Exposure and the Risk of Dementia: A Nested Case-Control Study. JAMA Intern. Med. 2019, 179, 1084-1093. [CrossRef] [PubMed]

255. O'Leary, O.F.; Dinan, T.; Cryan, J.F. Faster, better, stronger: Towards new antidepressant therapeutic strategies. Eur. J. Pharmacol. 2015, 753, 32-50. [CrossRef] [PubMed]

256. Wang, S.-M.; Han, C.; Lee, S.-J.; Patkar, A.A.; Masand, P.S.; Pae, C.-U. Five potential therapeutic agents as antidepressants: A brief review and future directions. Expert Rev. Neurother. 2015, 15, 1015-1029. [CrossRef] 
257. Anderson, I.M. Selective serotonin reuptake inhibitors versus tricyclic antidepressants: A meta-analysis of efficacy and toler-ability. J. Affect. Disord. 2000, 58, 19-36. [CrossRef]

258. Souery, D.; Papakostas, G.I.; Trivedi, M.H. Treatment-resistant depression. J. Clin. Psychiatry 2006, 67 (Suppl. 6), 16-22.

259. Trivedi, M.H.; Daly, E.J. Treatment strategies to improve and sustain remission in major depressive disorder. Dialogues Clin. Neurosci. 2008, 10, 377-384.

260. Berman, R.M.; Cappiello, A.; Anand, A.; Oren, D.A.; Heninger, G.R.; Charney, D.S.; Krystal, J.H. Antidepressant effects of ketamine in depressed patients. Biol. Psychiatry 2000, 47, 351-354. [CrossRef]

261. Zarate, C.A., Jr.; Singh, J.B.; Carlson, P.J.; Brutsche, N.E.; Ameli, R.; Luckenbaugh, D.A.; Charney, D.S.; Manji, H.K. A randomized trial of an N-methyl-D-aspartate antagonist in treatment-resistant major depression. Arch. Gen. Psychiatry 2006, 63, 856-864. [CrossRef]

262. Zarate, C.A., Jr.; Mathews, D.; Ibrahim, L.; Chaves, J.F.; Marquardt, C.; Ukoh, I.; Jolkovsky, L.; Brutsche, N.E.; Smith, M.A.; Luckenbaugh, D.A. A randomized trial of a low-trapping nonselective N-methyl-D-aspartate channel blocker in major depression. Biol. Psychiatry 2013, 74, 257-264. [CrossRef]

263. Trullas, R.; Skolnick, P. Functional antagonists at the NMDA receptor complex exhibit antidepressant actions. Eur. J. Pharmacol. 1990, 185, 1-10. [CrossRef]

264. Daly, E.J.; Trivedi, M.H.; Janik, A.; Li, H.; Zhang, Y.; Li, X.; Lane, R.; Lim, P.; Duca, A.R.; Hough, D.; et al. Efficacy of Esketamine Nasal Spray Plus Oral Antidepressant Treatment for Relapse Prevention in Patients with Treatment-Resistant Depression: A Randomized Clinical Trial. JAMA Psychiatry 2019, 76, 893-903. [CrossRef]

265. Nijs, M.; Wajs, E.; Aluisio, L.; Turkoz, I.; Daly, E.; Janik, A.; Borentain, S.; Singh, J.B.; DiBernardo, A.; Wiegand, F. Managing esketamine treatment frequency toward successful outcomes: Analysis of phase 3 data. Int. J. Neuropsychopharmacol. 2020, 23, 426-433. [CrossRef]

266. Kaur, U.; Pathak, B.K.; Singh, A.; Chakrabarti, S.S. Esketamine: A glimmer of hope in treatment-resistant depression. Eur. Arch. Psychiatry Clin. Neurosci. 2019, 271, 417-429. [CrossRef]

267. Ballard, E.D.; Zarate, C.A. The role of dissociation in ketamine's antidepressant effects. Nat. Commun. 2020, 11, 6431. [CrossRef]

268. Phillips, J.; Norris, S.; Talbot, J.; Birmingham, M.; Hatchard, T.; Ortiz, A.; Owoeye, O.; Batten, L.A.; Blier, P. Single, Repeated, and Maintenance Ketamine Infusions for Treatment-Resistant Depression: A Randomized Controlled Trial. Am. J. Psychiatry 2019, 176, 401-409. [CrossRef]

269. Phillips, J.L.; Norris, S.; Talbot, J.; Hatchard, T.; Ortiz, A.; Birmingham, M.; Owoeye, O.; Batten, L.A.; Blier, P. Single and repeated ketamine infusions for reduction of suicidal ideation in treatment-resistant depression. Neuropsychopharmacology 2019, 45, 606-612 [CrossRef]

270. Furey, M.L.; Drevets, W.C. Antidepressant efficacy of the antimuscarinic drug scopolamine: A randomized, placebo-controlled clinical trial. Arch. Gen. Psychiatry. 2006, 63, 1121-1129. [CrossRef]

271. Drevets, W.C.; Bhattacharya, A.; Furey, M.L. The antidepressant efficacy of the muscarinic antagonist scopolamine: Past findings and future directions. Adv. Pharmacol. 2020, 89, 357-386. [CrossRef]

272. Furey, M.L.; Pietrini, P.; Haxby, J.V.; Drevets, W.C. Selective Effects of Cholinergic Modulation on Task Performance during Selective Attention. Neuropsychopharmacology 2007, 33, 913-923. [CrossRef]

273. Lakstygal, A.M.; Kolesnikova, T.O.; Khatsko, S.L.; Zabegalov, K.N.; Volgin, A.D.; Demin, K.A.; Shevyrin, V.A.; Wappler-Guzzetta, E.A.; Kalueff, A.V. Dark classics in chemical neuroscience: Atropine, scopolamine, and other anticholinergic deliriant hallucinogens. ACS Chem. Neurosci. 2019, 10, 2144-2159. [CrossRef]

274. Clark, L.; Chamberlain, S.R.; Sahakian, B.J. Neurocognitive mechanisms in depression: Implications for treatment. Annu. Rev. Neurosci. 2009, 32, 57-74. [CrossRef]

275. Porter, R.J.; Gallagher, P.; Thompson, J.M.; Young, A.H. Neurocognitive impairment in drug-free patients with major depressive disorder. Br. J. Psychiatry 2003, 182, 214-220. [CrossRef]

276. Drevets, W.C.; Zarate, C.A.; Furey, M.L. Antidepressant Effects of the Muscarinic Cholinergic Receptor Antagonist Scopoloamine: A Review. Biol. Psychiatry. 2013, 73, 1156-1163. [CrossRef] [PubMed]

277. Voleti, B.; Navarria, A.; Liu, R.J.; Banasr, M.; Li, N.; Terwilliger, R.; Sanacora, G.; Eid, T.; Aghajanian, G.; Duman, R.S. Scopolamine rapidly increases mammalian target of rapamycin complex 1 signaling, synaptogenesis, and antidepressant behavioral responses. Biol. Psychiatry 2013, 74, 742-749. [CrossRef] [PubMed]

278. Li, N.; Lee, B.Y.; Liu, R.J.; Banasr, M.; Dwyer, J.; Iwata, M.; Li, X.Y.; Aghajanian, G.; Duman, R.S. mTORC1-dependent synapse formation underlies the rapid antidepressant effects of NMDA antagonists. Science 2010, 329, 959-964. [CrossRef] [PubMed]

279. Navarria, A.; Wohleb, E.S.; Voleti, B.; Ota, K.T.; Dutheil, S.; Lepack, A.E.; Dwyer, J.M.; Fuchikami, M.; Becker, A.; Drago, F.; et al. Rapid antidepressant actions of scopolamine: Role of medial prefrontal cortex and M1-subtype muscarinic acetylcholine receptors. Neurobiol. Dis. 2015, 82, 254-261. [CrossRef]

280. Witkin, J.M.; Overshiner, C.; Li, X.; Catlow, J.T.; Wishart, G.N.; Schober, D.A.; Heinz, B.A.; Nikolayev, A.; Tolstikov, V.V.; Anderson, W.H.; et al. M1 and M2 muscarinic receptor subtypes regulate antidepressant-like effects of the rapidly acting antidepressant scopolamine. J. Pharmacol. Exp. Ther. 2014, 351, 448-456. [CrossRef]

281. Wohleb, E.S.; Gerhard, D.; Thomas, A.; Duman, R.S. Molecular and Cellular Mechanisms of Rapid-Acting Antidepressants Ketamine and Scopolamine. Curr. Neuropharmacol. 2016, 15, 11-20. [CrossRef] 
282. Duman, R.S. Ketamine and rapid-acting antidepressants: A new era in the battle against depression and suicide. F1000Research 2018, 7, 659. [CrossRef]

283. Nenasheva, T.A.; Neary, M.; Mashanov, G.I.; Birdsall, N.J.; Breckenridge, R.A.; Molloy, J.E. Abundance, distribution, mobility and oligomeric state of $\mathrm{M}_{2}$ muscarinic acetylcholine receptors in live cardiac muscle. J. Mol. Cell. Cardiol. 2013, 57, 129-136. [CrossRef]

284. Levey, A.I. Muscarinic acetylcholine receptor expression in memory circuits: Implications for treatment of Alzheimer disease. Proc. Natl. Acad. Sci. USA 1996, 93, 13541-13546. [CrossRef]

285. Yamada, M.; Miyakawa, T.; Duttaroy, A.; Yamanaka, A.; Moriguchi, T.; Makita, R.; Ogawa, M.; Chou, C.J.; Xia, B.; Crawley, J.N.; et al. Mice lacking the M3 muscarinic acetylcholine receptor are hypophagic and lean. Nature 2001, 410, 207-212. [CrossRef]

286. Zhang, W.; Yamada, M.; Gomeza, J.; Basile, A.S.; Wess, J. Multiple Muscarinic Acetylcholine Receptor Subtypes Modulate Striatal Dopamine Release, as Studied with M1-M5Muscarinic Receptor Knock-Out Mice. J. Neurosci. 2002, 22, 6347-6352. [CrossRef]

287. Vilaro, M.T.; Palacios, J.M.; Mengod, G. Localization of M5 muscarinic receptor mRNA in rat brain examined by in situ hybrid-ization histochemistry. Neurosci. Lett. 1990, 114, 154-159. [CrossRef]

288. Basile, A.S.; Fedorova, I.; Zapata, A.; Liu, X.; Shippenberg, T.; Duttaroy, A.; Yamada, M.; Wess, J. Deletion of the M5 muscarinic ace-tylcholine receptor attenuates morphine reinforcement and withdrawal but not morphine analgesia. Proc. Natl. Acad. Sci. USA 2002, 99, 11452-11457. [CrossRef]

289. Thomsen, M.; Woldbye, D.P.D.; Wortwein, G.; Fink-Jensen, A.; Wess, J.; Caine, S.B. Reduced Cocaine Self-Administration in Musarinic M5 Acetylcholine Receptor-Deficient Mice. J. Neurosci. 2005, 25, 8141-8149. [CrossRef] [PubMed]

290. Chaudhury, D.; Walsh, J.J.; Friedman, A.K.; Juarez, B.; Ku, S.M.; Koo, J.W.; Ferguson, D.; Tsai, H.C.; Pomeranz, L.; Christoffel, D.J.; et al. Rapid regulation of depression-related behaviors by control of midbrain dopamine neurons. Nature 2013, 493, 532-536. [CrossRef] [PubMed]

291. Johnson, C.R.; Kangas, B.D.; Jutkiewicz, E.M.; Winger, G.; Bergman, J.; Coop, A.; Woods, J.H. Novel Antimuscarinic Antidepressant-like Compounds with Reduced Effects on Cognition. J. Pharmacol. Exp. Ther. 2021, 377, 336-345. [CrossRef] [PubMed]

292. Baker, R.; Showell, G.A.; Street, L.J.; Saunders, J.; Hoogsteen, K.; Freedman, S.B.; Hargreaves, R.J. Synthesis, physicochemical and conformational properties of (3R, 4R)-3-(3-cyclopropyl-1,2,4-oxadiazol-5-yl)-1-azabicyclo[2.2.1]heptane, a novel M1 selective muscarinic partial agonist. J. Chem. Soc. Chem. Comm. 1992, 11, 817-819. [CrossRef]

293. Freedman, S.B.; Dawson, G.R.; Iversen, L.L.; Baker, R.; Hargreaves, R.J. The design of novel muscarinic partial agonists that have functional selectivity in pharmacological preparations in vitro and reduced side-effect profile in vivo. Life Sci. 1993, 52, 489-495. [CrossRef]

294. Freedman, S.B.; Patel, S.; Harley, E.A.; Iversen, L.L.; Baker, R.; Showell, G.A.; Saunders, J.; McKnight, A.; Newberry, N.; Scholey, K.; et al. L-687,306: A functionally selective and potent muscarinic M1 receptor agonist. Eur. J. Pharmacol. 1992, 215, 135-136. [CrossRef]

295. Nunes, E.J.; Rupprecht, L.E.; Foster, D.; Lindsley, C.W.; Conn, P.J.; Addy, N.A. Examining the role of muscarinic M5 receptors in VTA cholinergic modulation of depressive-like and anxiety-related behaviors in rats. Neuropharmacology 2020, 171, 108089. [CrossRef] 